\title{
Spanish Industrial Unemployment: Some Explanatory Factors
}

\author{
By J. J. Dolado and J. L. Malo de Molina \\ Bank of Spain \\ and A. ZABALZA \\ Ministry of Economy and Finance and University of Valencia
}

\section{INTRODUCTION}

The high level of unemployment is probably the worst feature of the recent evolution of the Spanish economy. In 1970 the overall unemployment rate stood at 1 per cent of the civilian labour force; in 1984 it is estimated to have gone over the 20 per cent level. This is a substantial increase which has no parallel in any European country. Between 1970 and 1983 the average unemployment rate in the EEC rose by 8.6 percentage points, while the increase in Spain over the same period was of 17 points.

There is wide agreement among Spanish economists that these figures may be overstating the actual extent of the problem. The incidence of the underground economy and of fraudulent practices in unemployment registration may be wider than in most EEC countries. Nevertheless, we believe that, even taking into account these measurement difficulties, there has been a genuine worsening of the employment situation in Spain relative to that in other Western economies.

The purpose of this paper is to review the evidence of the last 20 years about the main variables that influence the Spanish labour market, and to attempt a preliminary explanation of the increase in unemployment. For the latter task we use the analytical framework recently developed by Layard and Nickell (1984a), and concentrate on those institutional factors that may have influenced the level of unemployment consistent with non-accelerating inflation (NAIRU).

The next section of the paper describes the key facts that we are trying to explain. Section II presents the analytical framework that we use, and discusses its theoretical foundations. These are dealt with very briefly, since they are fully explained in Layard and Nickell (1984a). Here we concentrate mostly on the empirical specification and on the description of the variables. The econometric results are presented in Section III and the explanation of the unemployment increase is given in Section IV. The final section summarizes our findings.

\section{The FACTS}

Spain's overall economic performance was outstanding during the second half of the 1960s and the beginning of the 1970s, but afterwards has deteriorated substantially. Figure 1 shows the growth of GDP, the rate of inflation and the rate of unemployment during the last 20 years. The behaviour of GDP resembles that of other European countries, although the rates of growth during the first ten years of the period were much higher in Spain than elsewhere in Europe. 


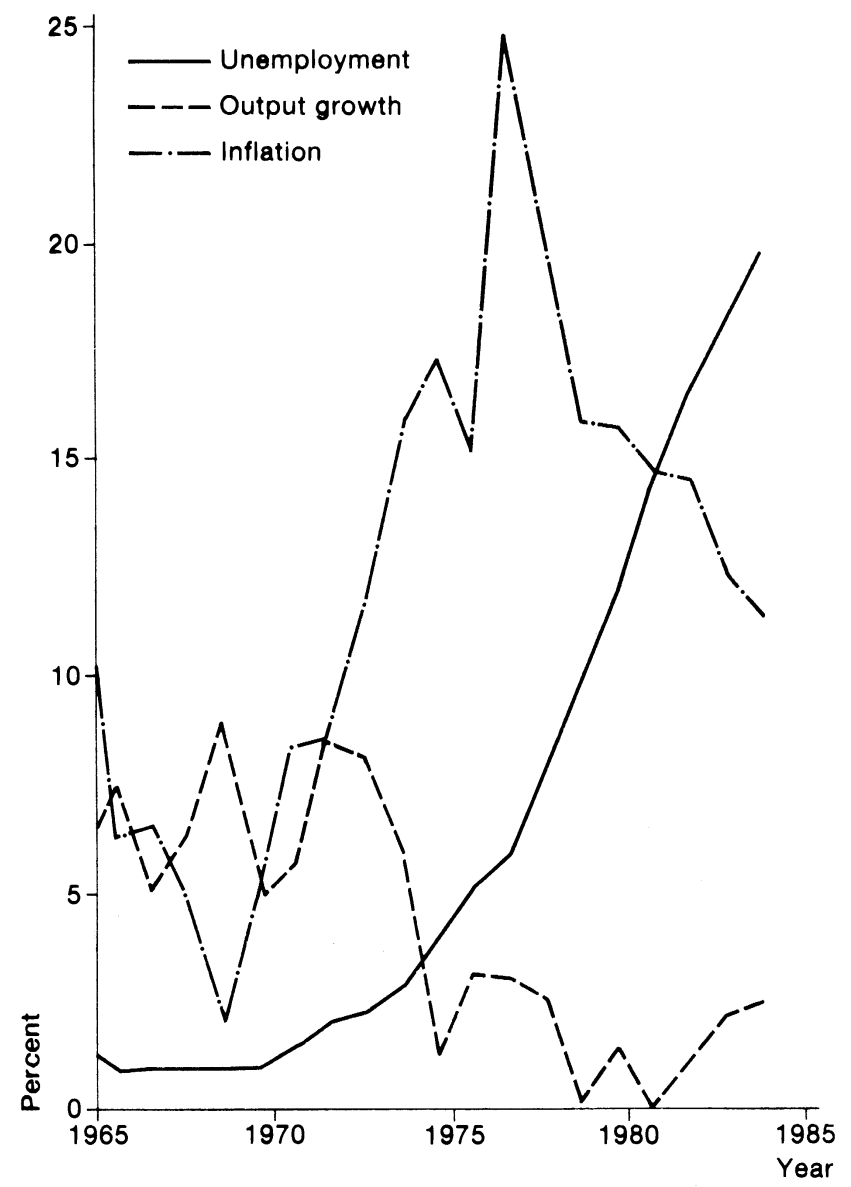

FIGURE 1. GDP growth, inflation and unemployment. 'Unemployment' refers to the overall unemployment rate of the civilian labour force; 'inflation', to the rate of growth of CPI; and 'output growth', to the rate of growth of GDP.

Sources: National Accounts and Bank of Spain.

The fall of this rate in 1975 roughly coincides with the general slowdown in economic activity that followed the first increase in the price of oil. The effects of the crisis on GDP are reflected in a decrease of almost 5 points in its average rate of growth. Although real output has managed to keep on growing even in the worst years of the crisis, it has doubtless experienced a severe reduction relative to its potential level. (Before 1974, real output was growing on average at more than 8 per cent per year.) Inflation has in general run at levels well above those of other European countries, and has proved difficult to curb in the last years of the period, even with widespread unemployment and with very low levels of output growth. Clearly, the worst feature of Spain's recent economic performance has been unemployment, which has grown to levels that ten years ago would have seemed unthinkable. We turn now to a more 
detailed look at this rate, which is going to be the main object of our analysis in this paper.

Figure 2 shows the evolution of employment and of the labour force. From 1964 until 1973, both labour force and employment increase consistently and practically in the same manner, with a gap between them of about 2 percentage points. After 1973, however, while the labour force stays more or less constant, employment falls very rapidly, showing in 1984 a gap of about 20 percentage points with respect to the labour force.

Figure 3 shows again the evolution of the overall unemployment rate since 1964, and gives details of how the agricultural, industrial, building and service sectors have contributed to this rate. ${ }^{1}$ Until 1970 the overall rate was practically stable, around the 1 per cent level. From that year onwards it began to show a moderate increase, reaching 2.7 per cent of the labour force in 1974 . Since then the rise has accelerated dramatically, particularly after 1977, and in the fourth quarter of 1984 the unemployment rate was 21.7 per cent, more than 12 times the rate 20 years earlier.

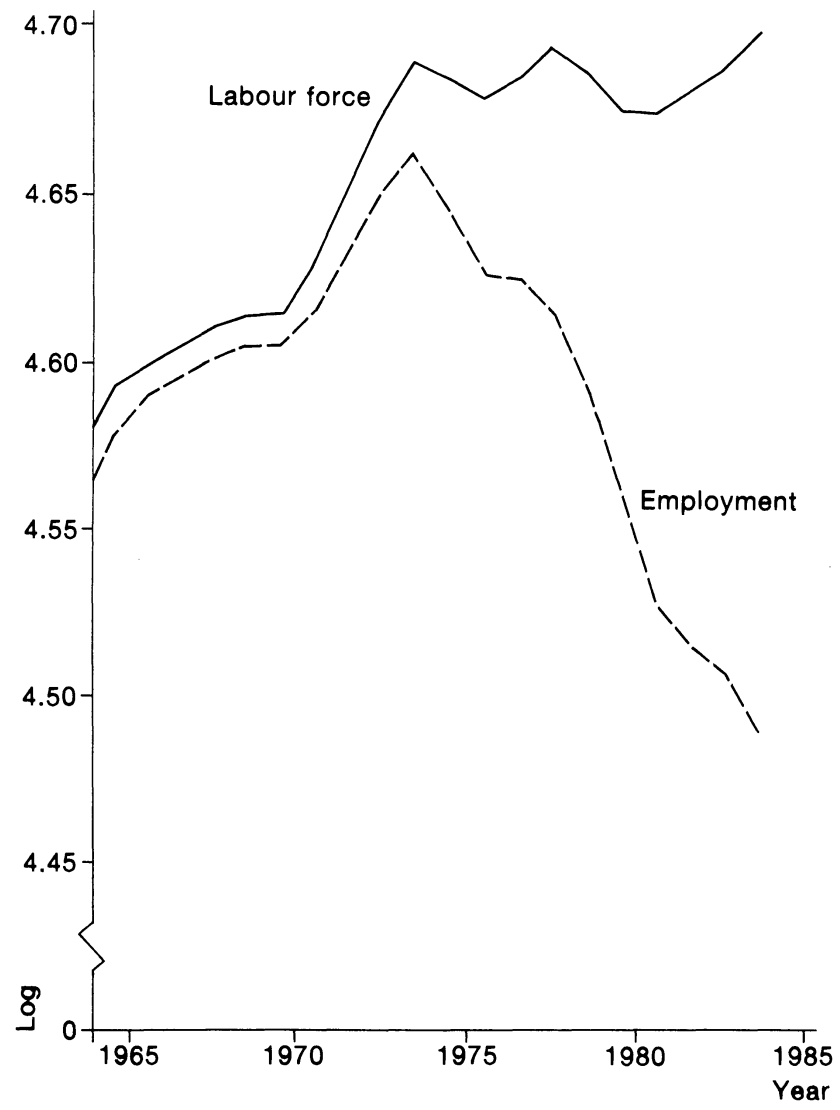

Figure 2. Total labour force and employment (logs). Source: Bank of Spain. 

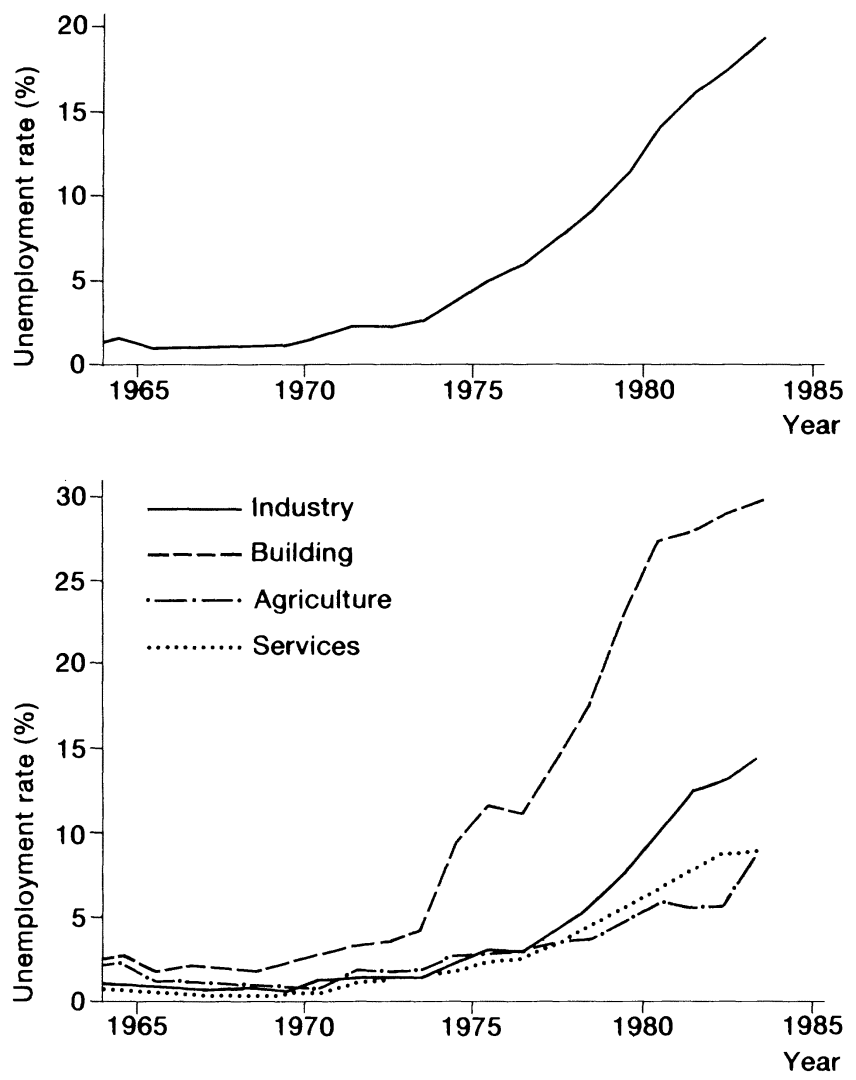

FIGURE 3. Unemployment rates: (a) overall rate; (b) sectoral rates. Source: Bank of Spain.

The sectoral rates shown in Figure 3(b) give some idea of the unemployment structure by sector. There was a clear lead in the building sector, where unemployment began to increase markedly in 1975. In the other sectors the change in the trend did not appear until after 1977, but since then, with the exception of agriculture, unemployment has risen consistently rapidly in all sectors. There is some deceleration in the rate of growth during the last two or three years. This deceleration hardly shows in the overall rate, but this is due to the substantial increase of unemployed school-leavers that has taken place towards the end of the period considered, and which is not taken into account in the sectoral rates.

The Spanish occupational structure has experienced substantial changes during the last 20 years. The share of building and industry in overall employment has remained more or less constant. That of agriculture, on the other hand, has gone down dramatically, the fall being completely absorbed by services. In 1964, agricultural employment represented 36.5 per cent of total employment, while employment in services was 31 per cent. In 1984 the shares were 17.6 and 49.0 per cent, respectively. This is, by any standard, a major 
structural change, which differentiates Spain from other European countries, and which could have had an influence on the overall unemployment rate.

We will abstract somewhat from these structural changes by concentrating our attention on the industrial sector. This is a choice forced upon us by data availability. Even for industry, it is impossible to go back before 1964 and to obtain reliable annual series of most of the variables of interest. For other sectors, the poor quality of the data, if not its outright absence, prevent any statistical analysis with even a minimum hope of rigour. ${ }^{2}$ By concentrating on the industrial sector we will also be able to compare some of our estimates with other results that have been obtained by independent research, and thus will be able to evaluate more confidently the meaning of our findings. ${ }^{3}$

The cost of labour has increased substantially in Spanish industry, and this could be one of the reasons behind the huge rise in unemployment. Figure 4 shows the evolution of four measures related to the price of labour. There has been an impressive rise in the real cost of labour faced by employers. In 1984 it had more than trebled with respect to 1964 . Social contributions paid by employers have also increased markedly, as is shown by the widening gap between the product wage and the real labour cost. In 1984 the average employer contribution in industry was 26 per cent of gross pay, whereas in 1964 it was only 15 per cent.

Since employee contributions represent a small fraction of gross pay, and since indirect taxes have been roughly constant over the period, the evolution of the real wage, also shown in Figure 4, is very similar to that of the product wage. On the other hand, the consumption wage, which subtracts income taxes from pay and is the closest approximation to what workers can potentially devote to consumption, has increased much less than the real wage, the difference representing the evolution of income taxes. ${ }^{4}$ While in 1983 the real wage was 3.46 times higher than in 1964 , the consumption wage was only $3 \cdot 24$ times higher.

Spanish industry has undergone an important process of modernization during the period considered, and it could be argued that most of the increases in labour costs documented above are simply reflecting productivity improvements. This is to some extent true, but we believe that, even after taking that into account, labour has recently become a much more expensive factor than it was before. A rough way of accounting for productivity improvements is to consider how real labour costs per unit of output have grown. ${ }^{5}$ From 1970 until 1982 these increased by 41.6 per cent in Spain, while in Italy (the EEC country with the highest rise) the corresponding index was only $17 \cdot 5$ per cent higher. In other EEC countries the increase was much smaller, and in Denmark and the Netherlands it was even negative. We thus conclude that, in comparison with other countries, Spanish industrial labour has become much more expensive than it was in the 1960 s, although this must to a certain extent be due to the relatively low level at which these labour costs started.

While the increase in labour costs is clearly endogenous to the labour market, the increase in the relative price of imported materials that also took place during this period is to a large extent exogenous. Figure 5 presents the evolution of this relative price during the period, which clearly charts very closely the incidence of the two oil price crises. There are three well differentiated periods. First, there is the period 1964-73, in which input prices were 


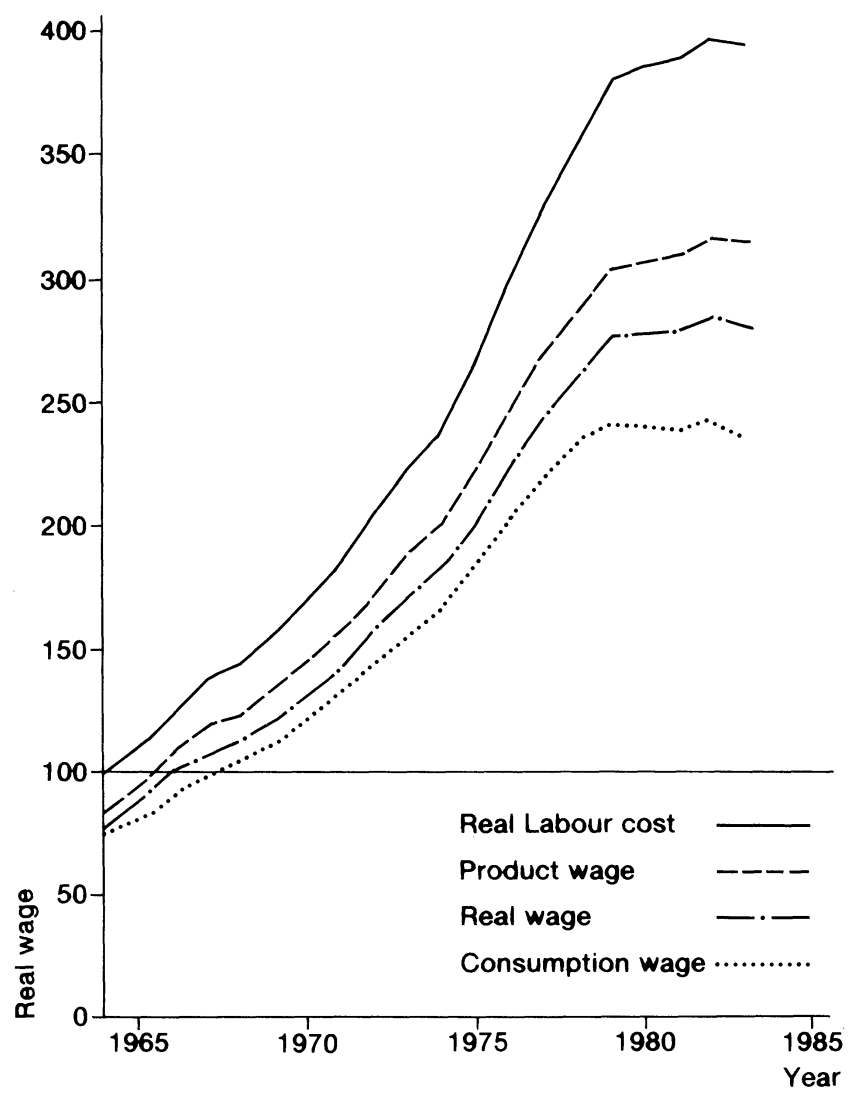

FIGURE 4. Real cost of labour, product, real and consumption wages. The 'product wage' is defined as $W / P$. 'Real labour cost' is defined as $W\left(1+t_{1}\right) / P$, where $W$ is gross pay, $P$ is product price and $t_{1}$ is employer's contribution to social security. The 'real wage' is defined as $\{W(1-$ $\left.\left.t_{4}\right) / P\left(1+t_{3}\right)\right\}$, where $t_{4}$ is employee's contribution to social security and $t_{3}$, indirect taxes. "Consumption wage' is defined as $\left\{W\left(1-t_{4}\right)\left(1-t_{2}\right) / P\left(1+t_{3}\right)\right\}$ where $t_{2}$ is income tax. Source: Bank of Spain.

more or less constant. Second, there is the period that begins with the first oil price rise, which in Spain shows up with a big increase in relative input prices, particularly in 1974, and with some translation of this rise into output prices in the following five years. Despite this rise in output prices, in 1979 the relative price of materials was 21.5 per cent higher than in 1973 . Third is the period from 1980 until now, which is dominated by the second oil price shock, and which has meant an increase in relative prices of an additional 66.1 per cent between 1983 and 1979. Overall, in 1983 relative input prices were $100 \cdot 3$ per cent higher than in 1964.

These huge changes in the relative price of labour and other inputs may have also produced a process of accelerated economic obsolescence of capital, which shows up most forcefully in industry. Some estimates of the stock of capital for that sector show that, while between 1964 and 1973 it grew at an 


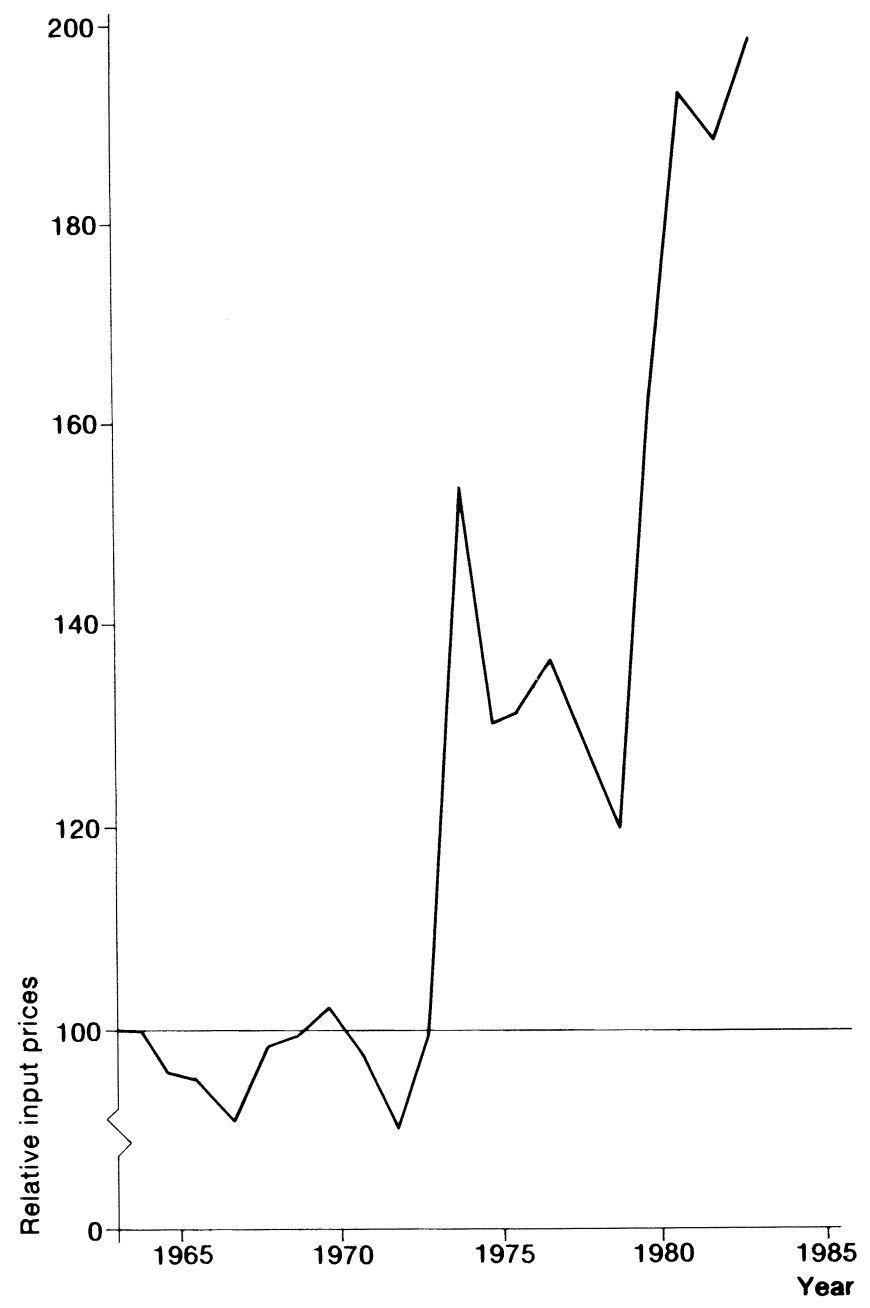

FIGURE 5. Relative imported input prices (price of imported inputs relative to product price). Source: Bank of Spain.

average annual rate of 4.5 per cent, between 1974 and 1978 this rate of growth went down to 3.6 per cent, and between 1979 and 1982 to 1.9 per cent. Thus, the squeezed or even negative profit margins experienced by firms may have had serious and durable consequences both on the level of installed capacity and on its potential growth.

We therefore see that the period under analysis has been characterized by substantial increases in two relative prices: the relative price of labour and the relative price of materials. ${ }^{6}$ The second has been quite widespread in Europe, but the severity of the first is a rather singular Spanish phenomenon. Both increases could, in principle, have affected labour demand and thus could 
explain the dramatic upsurge of unemployment in Spain. In the rest of the paper we attempt to consider these factors in the wider context of the labour market and try to evaluate the effect that they, or other possible influences, may have had on the evolution of unemployment.

\section{Analytical Framework}

\section{Theoretical considerations}

The theoretical model is taken from Layard and Nickell (1984a) and consists of three equations: a labour demand equation, a wage equation, and a price equation. Probably the best way to go about the description of this model is to start first with the employment and wage equations, and then to introduce the price equation.

The labour demand and wage equations together form a fairly conventional structural model of the labour market. The main innovations introduced by Layard and Nickell, which we also take into account in our empirical work, are the possibility that cyclical aggregate demand factors enter directly in the employment equation, the specification in level terms of the wage equation, and the much more explicit and detailed consideration of labour demand and supply factors in the wage equation. ${ }^{7}$

In logarithms, the basic structure of these two equations can be represented as follows:

$$
\begin{aligned}
& n=-\alpha(w-p)-\beta\left(p_{m}-p\right)+\gamma D+\lambda k+Z \\
& \left(w-p^{e}\right)=-\delta(l-n)-\eta\left(p_{m}-p\right)+\rho D+\mu(k-l)+Y .
\end{aligned}
$$

Employment, $n$, depends negatively on real wages $(w-p)$ and on relative input prices $\left(p_{m}-p\right),{ }^{8}$ and positively on a cyclical aggregate demand factor, $D$. Demand for labour is defined for a given stock of capital, $k$, and, under certain assumptions, in the long-run it will grow as this stock grows. Finally, $Z$ is a demand shift variable, and all Greek letters are positive parameters. Equation (1) is therefore a fairly standard labour demand equation, in which output has been substituted out, and in which possible direct aggregate demand effects are taken into account. ${ }^{9}$

Real wages, defined in terms of the expected price level, are in turn determined by both demand factors- $\left(p_{m}-p\right), D$ and $k$-and supply factors- $l$ and $Y$-where $l$ is the size of the labour force and $Y$ a supply shift variable. Factors that raise demand will raise real wages, and factors that raise supply will depress real wages. However, the equation should be interpreted not as a reduced form but as a structural form, at least when other variables suggested by wage bargaining models, such as outside labour opportunities-which here we proxy by $(l-n)$-also enter the model.

Writing the wage equation with actual real wages on the left-hand side (LHS) and introducing price shocks $\left(p^{e}-p\right)$ in the shift factor $Y$, we have that equations (1) and (2) determine real wages and employment (or unemployment), given all the other variables in the model. The resulting employment equation is:

$$
\begin{aligned}
n= & (l+\alpha \delta)^{-1}\left\{\alpha(\delta+\mu) l+(\lambda-\alpha \mu) k-(\beta-\alpha \eta)\left(p_{m}-p\right)+(\gamma-\alpha \rho) D\right. \\
& +(Z-\alpha Y)\} .
\end{aligned}
$$


Equation (3) makes unemployment dependent on aggregate demand besides other, as yet unspecified, demand and supply factors. This is unsatisfactory because, to the extent that aggregate demand can be controlled by the government, unemployment could be reduced at will, by simply increasing $D .^{10}$ It is therefore more sensible to think of (3) as a relationship that gives pairs of values of $n$ and $D$ that are consistent with labour market equilibrium, but which in itself cannot determine the equilibrium level of employment. For that, we need another equation to explain cyclical demand.

Within the context of this model, the only other channel through which demand can exert an influence is the pricing decisions of the imperfectly competitive firms assumed above. The mark-up of prices on costs is determined by cyclical demand, by relative import prices, by the capital-labour ratio and by expectational errors, which in the empirical model below are represented by second-differences on wages. ${ }^{11}$ Ignoring these expectational errors, the basic structure of this equation is the following:

$$
(p-w)=\sigma D+\phi\left(p_{m}-p\right)-\tau(k-l)+X
$$

where $X$ reflects other variables affecting the pricing decision.

Now, (4) and (1) - the labour demand function-also form a sub-model with two equations and three unknowns; the real wage, employment and cyclical demand. And, as previously, we can also eliminate real wages and this time interpret the resulting relationship as giving pairs of values of $n$ and $D$ that are consistent with product market equilibrium:

$$
n=(\alpha \sigma+\gamma) D+(\alpha \phi-\beta)\left(p_{m}-p\right)+(\lambda-\alpha \tau) k+\alpha \tau l+(\alpha X+Z) .
$$

For any given level of demand, prices will be determined according to (4) so that demand is satisfied and inflation is constant. But determining prices as a mark-up on costs means implictly also determining the real wage. And this real wage may not be consistent with labour market equilibrium, in the sense that the level of employment that follows may differ from the level of employment given by expression (3). Simultaneous labour and product market equilibrium can be obtained only when both (3) and (5) are satisfied. These form a system of two equations in the two unknowns $n$ and $D$. Any level of demand above the equilibrium $D$ given by (3) and (5) will increase employment but at the expense of increasing inflation. Setting $p=p^{e}$ and $w=w^{e}$, the level of $n$ corresponding to equilibrium $D$ gives the non-accelerating inflation level of employment and, for a given labour force, the non-accelerating inflation rate of unemployment. ${ }^{12}$

\section{Empirical specification}

In the following section we present the results of estimating equations (1), (2) and (4) using Spanish data for the industrial sector. Here we want to describe the empirical specification of these equations and the additional variables determining the shift factors $Z, Y$ and $X$.

Labour demand equation. Employment, $n$, refers to male and female full-time employment in the Spanish industrial sector. We ignore hours worked owing to lack of adequate data on this variable for the whole period considered.

The relative price of labour is defined as real labour cost; that is, average gross weekly pay plus employer's social security contributions, ${ }^{13}$ relative to output price. In logarithms, if gross pay is denoted by $w$, output price by $p$ 
and employer's contributions by $t_{1}$, real labour cost is defined as $\left(w+t_{1}-p\right)$. Again, owing to lack of reliable data on hours, we could not define this variable in terms of hourly earnings.

Relative input prices, $\left(p_{m}-p\right)$, are an index of prices of imported materials relative to output price. Given that in this paper we are considering only the industrial sector, it might have been appropriate to include also an index of intermediate goods from other sectors of the economy. Data limitations prevented us from constructing such index, but, given the relative size of the other two sectors that could have contributed inputs to industry (building and agriculture), we doubt that this omission has any significant effect on our results.

We tried several variables to proxy cyclical demand, but in the end the only ones that exerted a significant effect were an index of competitiveness (the real exchange rate) (e) and an after-tax real interest rate $(r) .{ }^{14}$ Among the variables initially tried, but which proved to be insignificant, were an index of world trade (deviations from trend) and a battery of adjusted and unadjusted deficits (as a proportion of GDP). We corrected the deficit both for inflation and for the cycle, and we carried out these corrections using several methods, but could never obtain any significant result.

The stock of capital is taken from Dolado and Malo de Molina (1984), ${ }^{15}$ and in the shift factor $Z$ we consider two additional variables; labouraugmenting technical progress $(a)$ and a measure of firing costs $(c)$. Technical progress is defined as in Layard and Nickell (1984b), and the logarithm of the series is smoothed by a trend. We also impose the restriction (accepted by the data) that the elasticity of employment with respect to this variable ought to be equal to the absolute value of the real wage elasticity minus one. The measure of firing costs is defined as the ratio of average redundancy payments to wages, and is included to take into account the increasing relaxation in employment protection legislation that has recently taken place in Spain. Although this definition captures fairly well the actual cost of firing that (on average) employers have had to face when reducing their labour force, it is somewhat unsatisfactory because it depends on unemployment, and this introduces an endogeneity problem. As unemployment has become widespread, redundancy has affected workers with long periods of tenure. And the result of this is that, despite the increasing firing facilities given by the legislation, average redundancy payments as a percentage of wages have grown since 1977. We adjust for this endogeneity problem by defining the redundancy pay for an employee of a given tenure.

Wage equation. The dependent variable of the wage equation is the real labour cost. Note that in principle the appropriate price variable in this equation is the expected price of consumption. This expected price can be substituted by the actual consumption price by including a term $\left(p^{e c}-p^{c}\right)$ on the RHS of the equation, where $p^{e c}$ is the expected consumption price. Also, if we want to define the variable in terms of output prices, as we do in equation (2), we must include indirect taxes $\left(t_{3}\right)$ on the RHS of the equation.

Given that we are considering only the industrial sector, we face an additional problem. To be consistent with the employment equation, the price variable must be defined as the price of industrial output, which clearly is only one component of the price of consumption. We took this into account 
by including in the RHS of the equation also the price of consumption relative to the price of industrial output; but this variable, as well as the expectational error term considered above, was never significant. ${ }^{16}$

The labour force is obtained by adding employment, as defined above, to unemployed people in industry.

The shift factor $Y$ includes the following variables.

(1) Taxes. In addition to indirect taxes as a proportion of GDP at market prices $\left(t_{3}\right)$, and employer's social security contributions as a proportion of wages $\left(t_{1}\right)$, which have been discussed above, we also include labour income tax and employee social security contributions as a proportion of wages $\left(t_{2}\right)$. As pointed out in Section I, these have increased substantially in the recent past and may have played an important role in collective bargaining, exerting some upward pressure on gross wages.

(2) Firing costs. The reduction that redundancy payments for given tenure have experienced in Spain could also have had a positive influence on gross pay.

(3) Replacement ratio. The larger unemployment benefits are, relative to wages, the smaller is the amount of labour supplied and, ceteris paribus, the higher the real wage. We tested for this possible influence on wages by including the average replacement ratio, but, as with redundancy payments, this measure is somewhat affected by endogeneity. With the number of unemployed people, unemployed duration has also increased during the period. Thus, since the amount of the benefit paid decreases with duration, the existence of more long-term unemployed people has meant that the average replacement ratio has tended to fall-and this despite a consistent improvement of unemployment benefits. So in the empirical analysis we try an adjusted replacement ratio, which corrects for this effect by holding constant the unemployment duration over the period.

(4) Mismatch. Unemployment arising from a mismatch between demand and supply should not exert any restraining influence on wages. So, one way of taking this into account is to include a measure of mismatch in the wage equation, which should appear with a positive sign. Mismatch is proxied by the absolute change in the proportion of manufacturing over total employment, and to some extent should capture the effect that the structural change of Spanish industry documented above may have had on industrial wages.

(5) Union pressure. This is a difficult variable to define for Spain. During the Franco regime all workers were compulsorily unionized, but this meant little for the real effect unions could have on wages. Also, strikes were forbidden, and there is no reliable record of the number and extent of industrial disputes, although they are known to have grown in importance towards the end of that regime. On the other hand, it is widely acknowledged that unions had a decisive influence on wages during the transition between the previous regime and the present constitutional monarchy, and that subsequently this influence has been greatly mitigated by the existence of regular and wideranging incomes policies.

We tried several definitions of this variable. Excluding days lost on strike, for lack of data, or union membership, for lack of meaning of this indicator, we were left with the alternative of modelling this variable on the basis of incomes policies. The problem here is that the previous regime can be characterized by a constant application of an incomes policy of some sort, and that 
during the present regime incomes policies have also played an important and almost permanent role. After experimenting with several alternatives, which included using information on the agreed ceilings on wage growth, we opted for a simple 1-0 dummy, which took the value 0 until 1973, the year of the death of Franco's prime minister, Mr Carrero-Blanco; 1 from 1973 until 1977, the year in which the Moncloa Pact was signed between government, opposition and unions; and again 0 since then.

We believe that this definition captures well the period during which the pressure of unions on wages was at its highest. Before 1974 political control of unions was too great to allow them any influence. The death of $\mathrm{Mr}$ Carrero-Blanco in 1973 is accepted to have really signalled the end of the Franco regime, and the signature of the Moncloa Pact in 1977 marked the beginning of a series of agreements on incomes policies which have since been an almost continuous feature of Spanish economic life.

(6) Other variables. Since labour-augmenting technical progress has been included in the employment equation, it must also be considered in the wage equation, where it can have a positive or a negative effect. This variable should in principle fulfil the same neutrality condition as capital, but the data rejected this restriction.

We would have liked also to include variables proxying changes in the intensity of search, but data on vacancies do not exist in Spain, so it was impossible to test whether the relationship between unemployment and vacancies has remained stable over the period or has changed. We tried lagged values of the unemployment rate to see whether there is any significant 'discouraged worker' effect when unemployment rises rapidly, but the results were always negative. ${ }^{17}$

Price equation. Practically all variables that enter into the price equation have already been defined. Demand and relative input prices should have a positive effect on the price mark-up, and productivity a negative effect. We include technical progress, which should also reduce the price mark-up for given levels of the other variables. Finally, the expectational error term is measured by a second-difference on nominal labour costs, which we expect to have a negative influence on the mark-up. The faster labour costs grow, the more likely it is that expected wages have fallen short of actual wages, and that the mark-up has been fixed below the optimal level.

\section{EMPIRICAL RESULTS}

\section{Employment equation}

Table 1 presents the results of estimating equation (1) on annual data on the industrial sector for the period 1964-83. The 20 observations available prevent us from attempting to estimate any complex dynamic structure for the equation or from carrying out proper stability tests. ${ }^{18}$ Thus the results should be taken with care and interpreted as preliminary until more data become available. However, it is interesting to note that the estimates obtained for this equation are similar to those reported in Dolado and Malo de Molina (1984), with quarterly data, similar to those obtained by Raymond (1983) with annual data, and quite consistent with both economic theory and findings based on data from other countries (Layard and Nickell, 1984b). 
TABLE 1

EMPLOYMENT EQUATION

Dependent variable, $n$

\begin{tabular}{ccc}
\hline $\begin{array}{c}\text { Independent } \\
\text { variables }\end{array}$ & Coefficients & $t$-ratios \\
\hline$n_{-1}$ & $0 \cdot 896$ & $14 \cdot 3$ \\
$\left(w+t_{1}-p\right)^{*}$ & $0 \cdot 276$ & $2 \cdot 2$ \\
$\left(w+t_{1}-p\right)_{-1}$ & $-0 \cdot 373$ & $2 \cdot 6$ \\
$\left(p_{m}-p\right)^{*}$ & $0 \cdot 0386$ & $2 \cdot 2$ \\
$\left(p_{m}-p\right)_{-1}$ & $-0 \cdot 0677$ & $4 \cdot 1$ \\
$c^{*}$ & - & - \\
$a$ & $-0 \cdot 007$ & $\left\{x_{L}^{2}(1)=2 \cdot 3\right\}$ \\
$k$ & $0 \cdot 104$ & $\left\{x_{L}^{2}(1)=3 \cdot 0\right\}$ \\
$D^{*}$ & $0 \cdot 073$ & $2 \cdot 7$ \\
\hline RHO & & $-0 \cdot 38(3 \cdot 2)$ \\
$s$ & & $0 \cdot 009$ \\
DW & & $2 \cdot 22$ \\
$R^{2}$ & & $0 \cdot 99$ \\
$x_{\text {iv }}^{2}(\cdot)$ & & $-0 \cdot 5(4)$ \\
wage elasticity & & $-0 \cdot 280$ \\
Other input price elasticity & & $-0 \cdot 065$ \\
Technical progress elasticity & & \\
\hline
\end{tabular}

Notes:

1. Estimates are obtained by IV

2. The demand variable is $D=e-1.95 r$

3. RHO is the AR(1) coefficient using Fair's instruments plus some additional instruments; $s$ is the standard error of the regression; $R^{2}$ is the coefficient of determination; DW is the Durbin-Watson statistic; $x_{L}^{2}(\cdot)$ test for the corresponding linear restriction, $x_{\mathrm{iv}}^{2}(\cdot)$ test for the validity of the instruments.

4. The $t$-ratios correspond to White's heteroscedasticity-consistent $t$-ratios.

5. $\left({ }^{*}\right)$ denotes instrumented variables. The instruments used were Fair's instruments, the tax wedge and lagged labour force-in total, 10 instruments.

The estimated long-run wage elasticity is found to be -0.94 , which is similar to the elasticity of $-1 \cdot 2$ obtained by Dolado and Malo de Molina (1984) with quarterly data. Real input prices have an overall negative influence on employment in both equations, which suggests that in the long run the output effect of relative price changes dominates over the substitution effect. The net effect, however-an elasticity of -0.28 -is much smaller than that exerted by wages.

To investigate possible direct demand effects, we first tried several variables on their own, and then, for efficiency, we ran the chosen linear combination as one single variable which we call $D$. Proceeding like this, in addition to overcoming some multicollinearity problems, also allows us to have a synthetic definition of demand effects for later use in the other equations. ${ }^{19}$ Deviations from world trade and several measures of the public sector deficit did not exert any effect on employment. ${ }^{20}$ In the end, the two variables selected were the real exchange rate and the after-tax real interest rate.

The elasticity of technical progress is imposed to be the absolute value of the wage elasticity minus one, and this, which is consistent with the hypothesis 
of labour-augmenting technical progress, is easily accepted by the data. The unit long-run elasticity of the stock of capital-that is, the assumption of constant returns to scale-is also imposed and is also roughly accepted by the data. $^{21}$

Among other factors that could affect employment, we tried the firing cost variable defined above. Since its effect was very insignificant, Table 1 omits this variable from the equation.

\section{Wage equation}

Table 2 shows the results of estimating equation (2). As mentioned above, we tried a measure of price surprises in the form of a second-difference of consumption prices, but this was never significant and is therefore not included in the equation. Since on the LHS of the equation we consider the price of industrial output, and since the real wage over which workers bargain ought to be defined in terms of overall consumption, we also tried a variable measuring the price of consumption relative to the price of industrial output (see n. 16 at end of paper), but again, this was not significant and is excluded from the equation. ${ }^{22}$ A final variable that was not significant, and is omitted from the equation, is the relative price of inputs. Thus, given the effect of this variable in the employment equation, the neutrality restriction relating to this variable (see n. 12) is not accepted by the data.

The rate of unemployment exerts an important and very significant restraining influence on real wages.

Taxes play an important role in wage determination. Owing to multicollinearity, we could not discriminate between the indvidual effect of different

TABLE 2

Real Wage Equation

Dependent variable $\left(w+t_{1}-p\right)$

\begin{tabular}{ccc}
\hline $\begin{array}{c}\text { Independent } \\
\text { variables }\end{array}$ & Coefficients & $t$-ratios \\
\hline$U_{-1}$ & $-3 \cdot 018$ & $4 \cdot 2$ \\
$\left(m m+m m_{-1}\right)^{*}$ & $0 \cdot 021$ & $1 \cdot 8$ \\
$\left(t_{1}+t_{2}+t_{3}\right)^{*}$ & 1 & $\left\{x_{L}^{2}(1)=1 \cdot 8\right\}$ \\
$r r^{*}$ & $0 \cdot 445$ & $3 \cdot 7$ \\
$c^{*}$ & $0 \cdot 445$ & $3 \cdot 7$ \\
$U P$ & $0 \cdot 065$ & $3 \cdot 4$ \\
$a^{*}$ & $0 \cdot 024$ & $2 \cdot 4$ \\
$t$ & $0 \cdot 069$ & $5 \cdot 2$ \\
$(k-l)^{*}$ & $1 \cdot 070$ & $\left\{x_{L}^{2}(1)=2 \cdot 8\right\}$ \\
\hline $\mathrm{RHO}$ & & $0 \cdot 019$ \\
$s$ & & $2 \cdot 28$ \\
$\mathrm{DW}$ & & $0 \cdot 99$ \\
$R^{2}$ & & $6 \cdot 23(5)$ \\
$\chi_{\mathrm{iv}}^{2}(\cdot)$ & & \\
\hline
\end{tabular}

Notes:

1,3 and 4 As for Table 1.

2 . $\left.{ }^{*}\right)$ denotes instrumented variables. The instruments used were the exogenous plus lagged endogeneous variables, lagged demand, lagged real government expenditure, and lagged real world trade-in total, 12 instruments. 
types of taxes, but we found that the sum of direct and indirect taxes (the tax wedge between the product and the consumption wage) had a positive and significant effect on real wages. The results suggest that taxes are fully borne by firms, as the restriction that the coefficient on the tax wedge should be unity is easily accepted by the data.

Among the supply variables tried, we found that the mismatch index, the replacement ratio, firing costs and the index of union pressure all exerted a positive effect on real wages. $^{23}$

The coefficient on the capital-labour ratio is imposed to be the inverse of the absolute value of the wage elasticity in the labour demand equation, and this neutrality restriction is accepted by the data. The data, however, reject the neutrality condition for technical progress, although this takes the expected positive sign in the wage equation. Thus, long-run unemployment is estimated to be dependent on technical progress. This result, for Spain and for the period considered, should not be taken as totally unexpected. The index of technical progress has changed quite dramatically during these years, and it would have been quite remarkable that a period of such rapid change could have captured the long-run neutrality property that we believe technical progress should have. Finally, we included a time trend which was also significant and positive, thus suggesting that productivity changes may have not been fully captured by the included variables.

\section{Price equation}

Table 3 shows the results of estimating equation (4). Econometrically speaking, the price equation is the one that performs best out of the three considered. All variables take the expected sign, all are well determined, and the dynamic

TABLE 3

PRICE EQuation

Dependent variable $\left(p-w-t_{1}\right)$

\begin{tabular}{ccc}
\hline $\begin{array}{c}\text { Independent } \\
\text { variables }\end{array}$ & Coefficients & $t$-ratios \\
\hline$\left(p_{-1}-w-t_{1}\right)$ & $0 \cdot 406$ & $5 \cdot 4$ \\
$\left(p_{-2}-w-t_{1}\right)$ & $0 \cdot 334$ & $10 \cdot 0$ \\
$\Delta^{2}\left(w+t_{1}\right)$ & $-0 \cdot 145$ & $2 \cdot 9$ \\
$D_{-1}$ & $0 \cdot 331$ & $2 \cdot 7$ \\
$\left(p_{m}-p\right)^{*}$ & $0 \cdot 096$ & $7 \cdot 9$ \\
$a^{*}$ & $-0 \cdot 033$ & $2 \cdot 2$ \\
$(k-l)$ & $-0 \cdot 278$ & $\left\{x_{L}^{2}(1)=3 \cdot 1\right\}$ \\
\hline $\mathrm{RHO}$ & & $-\overline{0064}$ \\
$s$ & & $2 \cdot 31$ \\
$\mathrm{DW}$ & & $0 \cdot 99$ \\
$R^{2}$ & & $4 \cdot 78(5)$ \\
$x_{\mathrm{iv}}^{2}(\cdot)$ & & \\
\hline
\end{tabular}

Notes:

1, 2, 3 and 4. As for Table 1.

2. $\left({ }^{*}\right)$ denotes instrumented variables. The instruments used were a constant, lags of prices, nominal labour cost, price of other inputs, lags of capital-labour ratio, real exchange rate, real interest rate, technical progress, government expenditure and mismatch-in total, 12 instruments. 
structure of the equation is very robust to specification changes. Perhaps the most interesting result is that relative input prices exert a substantial effect on the price mark-up, despite the fact that we have not been able to detect any input price influence in the wage determination process. Another interesting finding is the slowness with which increases in wages are passed into prices. The short-run wage elasticities are around $0 \cdot 12$ with median lags of around one year. The specific form of the lagged dependent variables results from the imposition of a unitary long-run elasticity with respect to wages in an original specification where the dependent variable was $p$. The unit elasticity was easily accepted in the long run, but it was rejected in the short run.

\section{Explaining SPANish Industrial Unemployment}

\section{Actual unemployment}

We first want to see to what extent these estimates explain the actual evolution of unemployment. That is, we want to evaluate how each of the variables considered, together with the level of cyclical demand, has contributed to the unemployment growth experienced during the last 20 years. Expression (3) above, expressed in terms of unemployment, answers precisely this question, and this (following Layard and Nickell, 1984a) is the accounting framework that we use in this section.

The nature of the model estimated in this paper does not allow us much precision about the dynamic structure of causes and effects. So we limit ourselves to explaining changes between averages of fairly large periods. We choose these periods according to the different regimes that can be identified in the explanatory variables. Probably, as far as recent economic history is concerned, the most representative of these is the relative price of imported inputs, which, as a result of the oil price crises, has gone through very clearly identifiable stages. As discussed in Section I (see Figure 5), there are three well differentiated periods as far as this variable is concerned: a first period of price stability (1964-73); a second period which is dominated by the initial increase in the price of oil (1974-79); and a third period, which begins with the second big increase in the price of oil and is continuing (1980-84). Given the small sample size available, we have preferred a slightly different distribution in order to make more equal the number of years in each subperiod and still keep the oil price shocks in two different subperiods. So the first subperiod runs from 1965 to 1971 , while the second and third subperiods cover the years 1972-78 and 1979-83, respectively. Then we assume that changes between the averages of these periods explain changes between the unemployment averages of the corresponding periods with a one-year lead; that is, 1966-72, 1973-79 and $1980-84 .^{24}$

Substituting the estimates obtained into equation (3), we arrive at the following expression:

$$
\begin{aligned}
u= & 0 \cdot 244\left(t_{1}+t_{2}+t_{3}\right)+0.079 r r+0.079 c+0.017 U P+0.010 \mathrm{~mm} \\
& +0.073\left(p_{m}-p\right)+0.023 a-0 \cdot 184 D+0.017 \text { time }+ \text { constant. }
\end{aligned}
$$

In Table 4 we show the actual changes that the explanatory variables have experienced between the three selected periods. It is interesting to note the 
TABLE 4

ACtual Changes of Explanatory Variables

(logarithmic differences)

\begin{tabular}{ccc}
\hline $\begin{array}{c}\text { Explanatory } \\
\text { variables }\end{array}$ & $1972-78$ & $\frac{1979-83}{1965-71}$ \\
\hline$\left(t_{1}+t_{2}+t_{3}\right)$ & $0 \cdot 047$ & $0 \cdot 105$ \\
$r r$ & $0 \cdot 055$ & $0 \cdot 070$ \\
$c$ & 0 & $-0 \cdot 180$ \\
$U P$ & $0 \cdot 710$ & $-0 \cdot 710$ \\
$m m$ & $-0 \cdot 150$ & $-0 \cdot 040$ \\
$\left(p_{m}-p\right)$ & $0 \cdot 280$ & $0 \cdot 315$ \\
$a$ & $0 \cdot 526$ & $0 \cdot 170$ \\
$D$ & $0 \cdot 231$ & $-0 \cdot 205$ \\
\hline
\end{tabular}

Note: $\left(p_{m}-p\right)$ has been corrected for real exchange rate changes.

very large increase in taxes. The tax wedge rose almost 5 percentage points between the first two periods and more than 10 points between the second and third, and most of this rise was due to employer contributions to social security and to labour income taxes. Changes in demand are also quite different depending on the period considered. During the first oil price crisis there was an expansion of demand, but during the second shock demand was a clear contractionary factor. The two changes in relative input prices show that the impact of the first oil price rise was smaller than that of the second. Finally, the data clearly suggest that technical improvements have taken place during the 20 years considered, but that the rate of modernization was higher between the first two periods than between the second and third.

Table 5 presents the contribution of each of the variables to unemployment growth. Looking first at the growth experienced between the first and second

TABLE 5

CONTRIBUTION OF EXPLANATORY VARIABLES TO THE GROWTH OF UNEMPLOYMENT (percentage points)

\begin{tabular}{ccc}
\hline & $1966-72$ & $\frac{1973-79}{1980-84}$ \\
\cline { 2 - 3 } Explanatory & $1973-79$ & $(2)$ \\
\hline variables & $(1)$ & $2 \cdot 56$ \\
$\left(t_{1}+t_{2}+t_{3}\right)$ & $1 \cdot 15$ & $0 \cdot 55$ \\
$r r$ & $0 \cdot 44$ & $-1 \cdot 42$ \\
$c$ & 0 & $-1 \cdot 21$ \\
$U P$ & $1 \cdot 21$ & -0.04 \\
$m m$ & -0.15 & $2 \cdot 30$ \\
$\left(p_{m}-p\right)$ & $2 \cdot 04$ & $0 \cdot 39$ \\
$a$ & $1 \cdot 21$ & $3 \cdot 77$ \\
$D$ & $-4 \cdot 25$ & $1 \cdot 02$ \\
Time & $1 \cdot 19$ & 7.92 \\
Explained change & $2 \cdot 84$ & 8.00 \\
Actual change & 2.52 & \\
\hline
\end{tabular}


periods (column (1)), we see that, for an observed increase of 2.52 percentage points, the model explains an increase of $2 \cdot 84$ points. The main contributors to unemployment during this first comparison were, in this order, the real price of materials, technical progress, union pressure, and the tax wedge. Time also contributed with $1 \cdot 2$ points, and may be capturing unmeasured productivity effects. These factors alone would have meant an increase in unemployment of almost 7 percentage points. However, between the two periods considered aggregate demand acted as a clear expansionary factor and this cut unemployment by more than 4 percentage points, leaving the net increase at about 3 percentage points. ${ }^{25}$

In column (2) of Table 5 we repeat the exercise for the period between the two oil price shocks. Here, out of an increase of unemployment of 8 percentage points, the model explains $7 \cdot 9$ points. With the exception of union pressure, all the factors that contributed positively to unemployment growth in the first comparison continue to exert an influence in the same direction in this second comparison. Among these, the tax wedge is now the most important contributor, followed by the relative price of materials, time, the replacement ratio, and technical change. The main differences with respect to the first comparison are the effect of demand, which now acts as a contractionary factor and adds 3.8 points to unemployment, and the effect of firing costs, which during this period have decreased and help to lower unemployment by 1.4 points. Overall, we find that the much higher growth of unemployment during this period is explained, on the one hand, by the negative effect that material prices and taxes have had on employment and, on the other, by the contractionary influence of demand.

So far we have looked at the factors that explain actual unemployment. But an even more interesting question is how actual unemployment compares with equilibrium unemployment, as this can give us an idea of the policy options and their consequences for inflation.

\section{Equilibrium unemployment}

The contributions shown in Table 5 have been calculated conditional on cyclical demand. This level of demand will in general be different from that associated with non-accelerating inflation. What we want to do now is to substitute out demand for the factors that explain their equilibrium level, and to see how the non-accelerating inflation unemployment rate (NAIRU) has evolved during the period. That is, we want to evaluate, on the basis of the estimates shown in Tables 1-3, the equilibrium unemployment level that comes out of the solution of equations (3) and (5). Our estimates imply:

$$
\begin{aligned}
u= & 0 \cdot 273 t+0 \cdot 088 r r+0 \cdot 088 c+0.019 U P+0.011 m m+0.088\left(p_{m}-p\right) \\
& +0.005 a+0.019 \text { time }+ \text { constant. }
\end{aligned}
$$

Expression (6) can now be used to calculate equilibrium unemployment. To get a sensible baseline it is assumed that equilibrium unemployment can be identified with the average unemployment rate of the period 1965-72, when inflation was roughly constant. Then for subsequent periods the corresponding level can be found using (6).

Table 6 shows the results of this exercise, which we identify as NAIRU (I). It also presents alternative estimates which are obtained by adding to 
TABLE 6

NAIRU ESTIMATES

(percentages)

\begin{tabular}{lccc}
\hline $\begin{array}{l}\text { Unemployment } \\
\text { rate }\end{array}$ & $1966-72$ & $1973-79$ & $1980-84$ \\
\hline Actual rate & $0 \cdot 90$ & $3 \cdot 42$ & $11 \cdot 42$ \\
NAIRU (I) & $0 \cdot 90$ & $6 \cdot 99$ & $11 \cdot 27$ \\
NAIRU (II) & $0 \cdot 90$ & $7 \cdot 31$ & $11 \cdot 35$ \\
\hline
\end{tabular}

Note: NAIRU (I) uses expression (6) to determine the increment over the baseline. NAIRU (II) adds to NAIRU (I) the discrepancy between the explained and the actual change in the unemployment rate in Table 5.

NAIRU (I) the part of the growth of actual unemployment that the model cannot explain. That is, we assume that the unexplained gap in Table 6 is all due to omitted factors which would affect the equilibrium rate. We call this new estimate NAIRU (II).

During the period 1973-79, the actual rate was well below the NAIRU. This means that, with the proviso explained in $n$. 25 , the success of the expansionary demand policy that took place during this period in keeping the unemployment rate low (see column (1) of Table 5) must have been achieved at the expense of accelerating prices. This is in fact corroborated by the data, which show that over this period inflation was both high and increasing. The last period, on the other hand, is characterized by a much higher NAIRU, and by an actual rate that is more or less around the level of the NAIRU. For this situation, the model predicts that prices should not have accelerated, and this is roughly what we find. In fact, inflation has tended to decrease, although the decreasing trend is to a very large extent determined by the substantial reductions in inflation achieved in the last two years. ${ }^{26}$

Given that, at the moment, the actual unemployment rate appears to be about the same level as the NAIRU, our results suggest that achieving a reduction in unemployment through an expansion of demand will be difficult without endangering the present performance on inflation. A safer course of action would involve policies directed at reducing the present level of the NAIRU.

Our findings indicate that more effective incomes policies could go some way towards this objective. A lower level of taxation could also reduce the NAIRU, but this would have to be implemented together with a reduction in public expenditure; otherwise the public deficit would increase, and we have not been able to show that this would have any positive effect on employment. ${ }^{27}$ Other types of measures that could reduce unemployment are those directed at increasing the flexibility of the labour market. The reduction in firing costs seems already to have exerted some beneficial effects in the last few years, and the fall in the extent of mismatch between supply and demand could also have helped to reduce unemployment. Finally, if the present tendency towards lower relative input prices is maintained, this should contribute significantly to lowering the equilibrium unemployment level, and thus should allow more scope for growth without inflation. 


\section{Conclusions}

This paper has reviewed the evidence of the last 20 years about the main variables that influence the Spanish labour market, and has attempted an explanation of the substantial increase in unemployment that has occurred during the period.

Our findings suggest that, as compared with the period 1966-72, the main factors behind the rise of unemployment during the first oil crisis (roughly, during the period 1973-79) were the real price of materials, technical progress, union pressure, and taxes. But against this we must count the effect of demand, whose expansion meant a reduction of unemployment. The second oil crisis (roughly, the period 1980-84) has meant a further and much larger increase in unemployment. Tax and real materials price increases again played an important role, but this time the problem has been aggravated by the contractionary pressure of cyclical demand.

We have also been able to identify the unemployment rate consistent with non-accelerating prices. During the first oil crisis actual unemployment is found to be well below the NAIRU, while during the second oil crisis actual and equilibrium unemployment are about the same. This casts some doubt about the effectiveness of expansionary demand policies. Given the present situation, reductions in unemployment through demand expansion should be difficult to achieve without rising inflation.

The model suggests that the policies most suited to reducing unemployment without increasing inflation are those directed at lowering the present level of the NAIRU. This can be achieved by more effective incomes policies, lower taxation, and a greater degree of labour market flexibility. Our estimates indicate that the maintenance of the decreasing trend in the real price of materials could also be an important factor in a future reduction of the NAIRU.

It is important to recall that these results have been obtained with data that are not as abundant and reliable as we would have liked. Although they conform with what we would expect from economic theory, and although they are quite consistent with findings obtained by researchers in other countries, until better data become available we believe they should be viewed with more reserve than that normally accorded to this type of research.

\section{ACKNOWLEDGMENTS}

We are grateful to C. Bean, R. Layard, S. Nickell, C. Pissarides and J. Viñals for their helpful suggestions on a previous draft of this paper.

\section{NOTES}

1. The Data Appendix gives a detailed definition of each variable and the sources used.

2. An attempt to investigate the overall unemployment rate would also have to deal with the substantial migration flows that have existed during these 20 years. During the 1960 s there was a large net outflow of workers to the rest of Europe, which by the late 1970s had turned into a net inflow. This clearly has a bearing on the definition of the labour force, but again, the poor quality of the data is bound to make any adjustment on this account extremely tentative.

3. On the other hand, it is evident that the concept of unemployment in a given sector is much more loose than that for the whole economy. In particular, as we have pointed out above, school-leavers (whatever the length of time that they have been unemployed) are excluded from the industrial unemployment rate.

4. Obviously this is a rough approximation, since it neglects the foreign component of consumption goods. 
5. The relevant concept here is that of 'normal productivity'. By using observed productivity we do not correct for increases arising from adjustments in employment and for the accelerated obsolescence and scrapping of capital and installed capacity (see Rojo, 1981, and Viñals, 1984, for a detailed discussion of these biases).

6. A much more detailed analysis of these and other labour-market-related data can be found in Malo de Molina (1983).

7. The introduction of cyclical demand factors, when output prices are already present in the equation, is justified on the basis of firm behaviour in an imperfect competitive market.

8. As far as relative input prices are concerned, it is assumed that the output effect dominates the substitution effect, and thus that an increase in relative input prices leads to a long-run fall in employment.

9. See Symons (1984) and Layard and Symons (1984) for a successful empirical estimation for Britain of a labour demand relationship specified only on relative prices. Dolado and Malo de Molina (1984) also obtain satisfactory results with this type of specification using quarterly Spanish data for the manufacturing sector.

10. We are assuming that the direct effect of demand on employment outweighs the indirect effect via wages.

11. This rough approximation is based upon the fact that both prices and wages, in their univariate time series representations, do not diverge from random walks in rates of growth, and therefore $p^{e}-p=-\Delta^{2} p$.

12. Labour force, stock of capital and input price neutrality in (3) require that $\mu=1 / \alpha$, $\lambda-\alpha \mu=0$, and $\beta-\alpha=0$, respectively. Input price, stock of capital and labour force neutrality in (5) imply $\alpha \phi-\beta=0 ; \lambda-\alpha \tau=0$ and $\alpha \tau=1$. These restrictions will all be tested with the data in the empirical work below.

13. Apart from these, there are no other significant employer taxes on labour.

14. The first variable reflects the fact that we are dealing with an open economy where demand fluctuations are a function of the degree of competitiveness and therefore should be included in $D$. The second variable is a candidate to pick up monetary and fiscal stance. (In fact, when deviations of real money balances from trend and adjusted measures of the budget deficit were introduced, together with the real interest rate, a high degree of collinearity was present among the three variables.) Since, in an era of floating exchange rates, both competitiveness and real interest rates tend to be correlated, they have been estimated in a synthetic way.

15. The procedure to measure the capital stock takes into account a variable depreciation rate to capture the economic obsolescence experienced by installed capacity. Ignoring this could lead to overestimation of the capital stock and also, given that this is taken as exogenous, to biased results (see Artus, 1984)

16. If $P$ is the price of industrial output, $P^{e c}$ is the expected price of consumption and $P^{c}$ the actual price of consumption, then $W / P^{e c}=(W / P)\left(P / P^{c}\right)\left(P^{c} / P^{e c}\right)$. Passing the last two parentheses to the RHS of the equation gives the specification discussed in the text.

17. We also tried to approximate vacancies by the inverse of the unemployment rate, given that vacancy and unemployment rates appear empirically to be related in a hyperbolic fashion; but the results always failed to support the combined specification.

18. Usual Chow tests are not valid when using an IV estimation method (see Pagan and Hall, 1984). In order to use an appropriate Wald test, we need to estimate the equation over the full period, including dummy variables and instruments consisting of vectors of zeros for the first period and actual data for the second. Since the maximum number of instruments was 12 in all the estimated equations, it was impossible to compute the tests given the available sample. None the less, estimating the equations until 1980 and using Chow tests, there was no sign of serious instability in any of the equations.

19. In theory, the variable proxying cyclical demand deviations should be the same in all three equations.

20. The contemporaneous effect of both variables was always negative and non-significant, while the lagged values gave the correct signs but very low $t$-ratios, implying in addition a synthetic variable which was also non-significant.

21. From Gallant and Jorgenson (1979), we use the following test statistic in order to test linear restrictions in the IV framework:

$$
x_{L}^{2}(q)=\frac{T-k}{\sigma_{u}^{2}}\left(\sigma_{u}^{2} R_{u}^{2}-\sigma_{R}^{2} R_{R}^{2}\right)
$$

where $\sigma_{u}^{2}$ and $R_{u}^{2}$ denote the variance estimate and coefficient of determination from the unrestricted equation; and $\sigma_{R}^{2}$ and $R_{R}^{2}$ denote similar statistics for the restricted equation.

22. This inability to capture the unanticipated inflation term is in fact a serious problem, as pointed out in Nickell and Andrews (1983), since this term might proxy demand shocks. If we have not represented these adequately, they will be relegated to the error term, invalidating most of the current dated instruments related to aggregate demand. In order to deal with this problem we have used only lagged instruments in the equation, except for the capital stock. 
23. For efficiency, the coefficients on the replacement ratio and firing costs, which are very similar, were restricted to be the same. The data accept this restriction.

24. This procedure, which is also used in Layard and Nickell (1984a), is an approximate way of representing the estimated dynamic structure of the model, which, as can be seen in Tables $1-3$, and depending on the variable considered, varies between zero and two lags.

25. We must note that, for the estimates obtained here, it is not quite correct to attribute changes in unemployment arising from changes in the variable $D$ to pure demand factors. Neither the real exchange rate nor the real interest rate are exogenous factors, and one of the variables that to some extent could be taken as being under the control of the government-the public deficit-proved not to exert any significant effect.

26. In 1980 inflation was $15 \cdot 5$ per cent and in 1982 it was $14 \cdot 4$ per cent. In 1983 it went down by $2 \cdot 2$ points to $12 \cdot 2$ per cent, and in 1984 by $3 \cdot 2$ points to $9 \cdot 0$ per cent.

27. Similar results are reached by Mauleón and Pérez (1984), who tackle the consequences of recent high budget deficits in terms of its 'crowding-out' effects.

\section{REFERENCES}

Artus, J. (1984). The disequilibrium real wage rate hypothesis; an empirical evaluation. IMF Staff Papers, 31, 249-302.

Dolado, J. and Malo de Molina, J. L. (1984). Un estudio econométrico de la demanda de trabajo en la industria. Unpublished paper, Bank of Spain, Research Department, D.P. 12/84.

$\rightarrow$ Gallant, A. and Jorgenson, D. (1979). Statistical inference for a system of simultaneous, non-linear, implicit equations in the context of instrumental variables estimation. Journal of Econometrics, 11, 275-302.

LAYARD, R. and NiCKell, S. (1984a). The causes of British unemployment. Unpublished paper, London School of Economics Centre for Labour Economics, W.P. 642.

(1984b). Unemployment and real wages in Europe, Japan and the US. Unpublished paper, London School of Economics Centre for Labour Economics, W.P. 677.

LAYARD, R. and SYMONS J. (1984). Neoclassical demand for labour functions for six major economies. Economic Journal, 94, 788-99.

Malo de Molina, J. L. (1983). Rigidez o flexibilidad en el mercado de trabajo. La experiencia Española durante la crisis. Estudios Económicos, 34, 1-61.

Mauleón, I. and PÉRez, J. (1984). Interest rate determinants and consequences for macroeconomic performance in Spain. Unpublished paper, Bank of Spain, Research Department, W.P. 8420 .

Nickell, S. and ANDrews, M. (1983). Unions, real wages and employment in Britain, 1951-79. Oxford Economic Papers, 35, 507-530.

Pagan, A. and Hall, A. (1983). Testing residuals. Econometric Review, 5, 159-218.

RAYMOND, J. L. (1983). Una nota sobre demanda de empleo, niveles de actividad económica y salarios reales. Papeles de Economía, 15, 276-281.

Rojo, L. A. (1981). Desempleo y factores reales. Papeles de Economía, 8, 124-136.

Symons, J. (1984). The demand for labour in British manufacturing. Unpublished paper, London School of Economics, Centre for Labour Economics, D.P. 91.

ViÑals, J. (1984). Medición de la productividad del trabajo y clases de paro. Investigaciones Económicas, 25, 19-30.

(1985). El déficit público y sus efectos macroeconómicos. Unpublished paper, Bank of Spain, Research Department (mimeo). 


\section{Data Appendices}

AUSTRIA

\begin{tabular}{lccccccc}
\hline & & & & & & \\
& & $\log L$ & $\log N$ & $\log Y$ & $V$ & $C U$ & $\log \frac{W\left(1+t_{1}\right)}{P}$ \\
\hline 1964 & $0 \cdot 271$ & $7 \cdot 795$ & $7 \cdot 768$ & $6 \cdot 085$ & $0 \cdot 168$ & 85 & $-0 \cdot 945$ \\
1965 & $0 \cdot 268$ & $7 \cdot 803$ & $7 \cdot 775$ & $6 \cdot 114$ & $0 \cdot 176$ & 86 & $-0 \cdot 893$ \\
1966 & $0 \cdot 251$ & $7 \cdot 803$ & $7 \cdot 778$ & $6 \cdot 164$ & $0 \cdot 192$ & 86 & $-0 \cdot 835$ \\
1967 & $0 \cdot 266$ & $7 \cdot 793$ & $7 \cdot 766$ & $6 \cdot 192$ & $0 \cdot 137$ & 83 & $-0 \cdot 768$ \\
1968 & $0 \cdot 294$ & $7 \cdot 787$ & $7 \cdot 758$ & $6 \cdot 233$ & $0 \cdot 118$ & 85 & $-0 \cdot 739$ \\
1969 & $0 \cdot 277$ & $7 \cdot 793$ & $7 \cdot 765$ & $6 \cdot 286$ & $0 \cdot 144$ & 88 & $-0 \cdot 693$ \\
1970 & $0 \cdot 239$ & $7 \cdot 802$ & $7 \cdot 779$ & $6 \cdot 348$ & $0 \cdot 190$ & 89 & $-0 \cdot 643$ \\
1971 & $0 \cdot 207$ & $7 \cdot 827$ & $7 \cdot 806$ & $6 \cdot 398$ & $0 \cdot 228$ & 88 & $-0 \cdot 568$ \\
1972 & $0 \cdot 192$ & $7 \cdot 848$ & $7 \cdot 829$ & $6 \cdot 458$ & $0 \cdot 247$ & 88 & $-0 \cdot 524$ \\
1973 & $0 \cdot 156$ & $7 \cdot 882$ & $7 \cdot 866$ & $6 \cdot 506$ & $0 \cdot 253$ & 86 & $-0 \cdot 481$ \\
1974 & $0 \cdot 153$ & $7 \cdot 900$ & $7 \cdot 885$ & $6 \cdot 545$ & $0 \cdot 217$ & 86 & $-0 \cdot 440$ \\
1975 & $0 \cdot 204$ & $7 \cdot 905$ & $7 \cdot 885$ & $6 \cdot 541$ & $0 \cdot 117$ & 81 & $-0 \cdot 351$ \\
1976 & $0 \cdot 201$ & $7 \cdot 916$ & $7 \cdot 896$ & $6 \cdot 586$ & $0 \cdot 109$ & 81 & $-0 \cdot 307$ \\
1977 & $0 \cdot 183$ & $7 \cdot 933$ & $7 \cdot 915$ & $6 \cdot 628$ & $0 \cdot 117$ & 81 & $-0 \cdot 272$ \\
1978 & $0 \cdot 208$ & $7 \cdot 943$ & $7 \cdot 922$ & $6 \cdot 634$ & $0 \cdot 107$ & 81 & $-0 \cdot 237$ \\
1979 & $0 \cdot 200$ & $7 \cdot 984$ & $7 \cdot 928$ & $6 \cdot 680$ & $0 \cdot 113$ & 83 & $-0 \cdot 218$ \\
1980 & $0 \cdot 187$ & $7 \cdot 952$ & $7 \cdot 933$ & $6 \cdot 709$ & $0 \cdot 131$ & 83 & $-0 \cdot 184$ \\
1981 & $0 \cdot 242$ & $7 \cdot 961$ & $7 \cdot 937$ & $6 \cdot 708$ & $0 \cdot 091$ & 83 & $-0 \cdot 161$ \\
1982 & $0 \cdot 367$ & $7 \cdot 963$ & $7 \cdot 925$ & $6 \cdot 718$ & $0 \cdot 062$ & 80 & $-0 \cdot 176$ \\
1983 & $0 \cdot 445$ & $7 \cdot 959$ & $7 \cdot 914$ & $6 \cdot 739$ & $0 \cdot 056$ & 79 & $-0 \cdot 157$ \\
1984 & $0 \cdot 454$ & $7 \cdot 964$ & $7 \cdot 917$ & $6 \cdot 760$ & $0 \cdot 063$ & 81 & $-0 \cdot 157$ \\
\hline
\end{tabular}

\begin{tabular}{cccccccc}
\hline & $\log (K / L)$ & $\Delta \log W$ & $\Delta \log P$ & $U P$ & $t_{1}$ & $t_{2}$ & $t_{3}$ \\
\hline 1964 & $-0 \cdot 170$ & & & $65 \cdot 13$ & $0 \cdot 154$ & $0 \cdot 159$ & $0 \cdot 137$ \\
1965 & $-0 \cdot 150$ & $0 \cdot 103$ & $0 \cdot 054$ & $64 \cdot 78$ & $0 \cdot 158$ & $0 \cdot 172$ & $0 \cdot 137$ \\
1966 & $-0 \cdot 120$ & $0 \cdot 094$ & $0 \cdot 036$ & $64 \cdot 65$ & $0 \cdot 157$ & $0 \cdot 181$ & $0 \cdot 141$ \\
1967 & $-0 \cdot 081$ & $0 \cdot 099$ & $0 \cdot 034$ & $64 \cdot 10$ & $0 \cdot 160$ & $0 \cdot 181$ & $0 \cdot 139$ \\
1968 & $-0 \cdot 047$ & $0 \cdot 057$ & $0 \cdot 031$ & $64 \cdot 72$ & $0 \cdot 163$ & $0 \cdot 177$ & $0 \cdot 146$ \\
1969 & $-0 \cdot 023$ & $0 \cdot 078$ & $0 \cdot 035$ & $64 \cdot 35$ & $0 \cdot 167$ & $0 \cdot 193$ & $0 \cdot 145$ \\
1970 & $-0 \cdot 000$ & $0 \cdot 102$ & $0 \cdot 053$ & $63 \cdot 63$ & $0 \cdot 168$ & $0 \cdot 204$ & $0 \cdot 147$ \\
1971 & $0 \cdot 014$ & $0 \cdot 136$ & $0 \cdot 060$ & $62 \cdot 18$ & $0 \cdot 167$ & $0 \cdot 204$ & $0 \cdot 149$ \\
1972 & $0 \cdot 035$ & $0 \cdot 118$ & $0 \cdot 073$ & $61 \cdot 37$ & $0 \cdot 165$ & $0 \cdot 208$ & $0 \cdot 156$ \\
1973 & $0 \cdot 042$ & $0 \cdot 124$ & $0 \cdot 077$ & $59 \cdot 79$ & $0 \cdot 161$ & $0 \cdot 203$ & $0 \cdot 162$ \\
1974 & $0 \cdot 064$ & $0 \cdot 130$ & $0 \cdot 091$ & $59 \cdot 48$ & $0 \cdot 164$ & $0 \cdot 212$ & $0 \cdot 152$ \\
1975 & $0 \cdot 093$ & $0 \cdot 144$ & $0 \cdot 063$ & $59 \cdot 76$ & $0 \cdot 173$ & $0 \cdot 199$ & $0 \cdot 141$ \\
1976 & $0 \cdot 117$ & $0 \cdot 097$ & $0 \cdot 055$ & $59 \cdot 74$ & $0 \cdot 175$ & $0 \cdot 210$ & $0 \cdot 136$ \\
1977 & $0 \cdot 136$ & $0 \cdot 083$ & $0 \cdot 051$ & $59 \cdot 15$ & $0 \cdot 178$ & $0 \cdot 224$ & $0 \cdot 141$ \\
1978 & $0 \cdot 157$ & $0 \cdot 072$ & $0 \cdot 051$ & $59 \cdot 06$ & $0 \cdot 195$ & $0 \cdot 257$ & $0 \cdot 134$ \\
1979 & $0 \cdot 184$ & $0 \cdot 057$ & $0 \cdot 041$ & $59 \cdot 18$ & $0 \cdot 198$ & $0 \cdot 260$ & $0 \cdot 135$ \\
1980 & $0 \cdot 212$ & $0 \cdot 080$ & $0 \cdot 050$ & $59 \cdot 56$ & $0 \cdot 203$ & $0 \cdot 269$ & $0 \cdot 133$ \\
1981 & $0 \cdot 232$ & $0 \cdot 081$ & $0 \cdot 061$ & $58 \cdot 51$ & $0 \cdot 207$ & $0 \cdot 278$ & $0 \cdot 135$ \\
1982 & $0 \cdot 255$ & $0 \cdot 046$ & $0 \cdot 065$ & $59 \cdot 47$ & $0 \cdot 213$ & $0 \cdot 275$ & $0 \cdot 132$ \\
1983 & $0 \cdot 280$ & $0 \cdot 051$ & $0 \cdot 037$ & $59 \cdot 49$ & $0 \cdot 219$ & $0 \cdot 282$ & $0 \cdot 133$ \\
1984 & $0 \cdot 297$ & $0 \cdot 042$ & $0 \cdot 046$ & & $0 \cdot 219$ & $0 \cdot 285$ & $0 \cdot 143$ \\
\hline
\end{tabular}




\begin{tabular}{cccccccc}
\hline \multicolumn{1}{c}{$H$} & $T H$ & $\log A$ & $\log N^{*}$ & $\Delta \log P C$ & $\Delta \log H P R$ & $L U$ \\
\hline 1964 & $2229 \cdot 2$ & & & & & $-0 \cdot 182$ & \\
1965 & $2192 \cdot 5$ & & & & $0 \cdot 0455$ & $-0 \cdot 144$ & \\
1966 & $2195 \cdot 2$ & $2185 \cdot 2$ & $4 \cdot 707$ & $7 \cdot 749$ & $0 \cdot 0229$ & $-0 \cdot 097$ & \\
1967 & $2172 \cdot 9$ & $2185 \cdot 2$ & $4 \cdot 800$ & $7 \cdot 738$ & $0 \cdot 0392$ & $-0 \cdot 047$ & \\
1968 & $2188 \cdot 6$ & $2185 \cdot 2$ & $4 \cdot 890$ & $7 \cdot 750$ & $0 \cdot 0248$ & $-0 \cdot 006$ & \\
1969 & $2184 \cdot 7$ & $2185 \cdot 2$ & $4 \cdot 985$ & $7 \cdot 770$ & $0 \cdot 0353$ & $0 \cdot 042$ & \\
1970 & $2127 \cdot 3$ & $2123 \cdot 5$ & $5 \cdot 098$ & $7 \cdot 827$ & $0 \cdot 0447$ & $0 \cdot 117$ & \\
1971 & $2090 \cdot 8$ & $2101 \cdot 7$ & $5 \cdot 218$ & $7 \cdot 846$ & $0 \cdot 0485$ & $0 \cdot 157$ & $0 \cdot 228$ \\
1972 & $2064 \cdot 7$ & $2070 \cdot 8$ & $5 \cdot 343$ & $7 \cdot 889$ & $0 \cdot 0626$ & $0 \cdot 207$ & $0 \cdot 219$ \\
1973 & $2064 \cdot 7$ & $2059 \cdot 7$ & $5 \cdot 460$ & $7 \cdot 910$ & $0 \cdot 0639$ & $0 \cdot 217$ & $0 \cdot 207$ \\
1974 & $2070 \cdot 0$ & $2059 \cdot 7$ & $5 \cdot 594$ & $7 \cdot 917$ & $0 \cdot 0952$ & $0 \cdot 235$ & $0 \cdot 264$ \\
1975 & $1997 \cdot 0$ & $1997 \cdot 4$ & $5 \cdot 708$ & $7 \cdot 899$ & $0 \cdot 0763$ & $0 \cdot 267$ & $0 \cdot 199$ \\
1976 & $1970 \cdot 9$ & $1975 \cdot 4$ & $5 \cdot 825$ & $7 \cdot 922$ & $0 \cdot 0629$ & $0 \cdot 314$ & $0 \cdot 234$ \\
1977 & $1965 \cdot 7$ & $1944 \cdot 9$ & $5 \cdot 919$ & $7 \cdot 951$ & $0 \cdot 0526$ & $0 \cdot 341$ & $0 \cdot 210$ \\
1978 & $1960 \cdot 5$ & $1944 \cdot 5$ & $6 \cdot 004$ & $7 \cdot 926$ & $0 \cdot 0418$ & $0 \cdot 341$ & $0 \cdot 190$ \\
1979 & $1960 \cdot 5$ & $1944 \cdot 2$ & $6 \cdot 085$ & $7 \cdot 947$ & $0 \cdot 0427$ & $0 \cdot 381$ & $0 \cdot 194$ \\
1980 & $1939 \cdot 6$ & $1943 \cdot 8$ & $6 \cdot 168$ & $7 \cdot 948$ & $0 \cdot 0625$ & $0 \cdot 416$ & $0 \cdot 194$ \\
1981 & $1918 \cdot 8$ & $1943 \cdot 4$ & $6 \cdot 246$ & $7 \cdot 920$ & $0 \cdot 0719$ & $0 \cdot 422$ & $0 \cdot 161$ \\
1982 & $1934 \cdot 4$ & $1943 \cdot 0$ & $6 \cdot 327$ & $7 \cdot 914$ & $0 \cdot 0621$ & $0 \cdot 436$ & $0 \cdot 196$ \\
1983 & $1929 \cdot 2$ & $1942 \cdot 6$ & $6 \cdot 404$ & $7 \cdot 910$ & $0 \cdot 0310$ & $0 \cdot 471$ & $0 \cdot 258$ \\
1984 & $1942 \cdot 7$ & $1942 \cdot 2$ & $6 \cdot 484$ & $7 \cdot 911$ & $0 \cdot 0547$ & $0 \cdot 481$ & $0 \cdot 283$ \\
\hline
\end{tabular}

\section{List of variables}

$U \quad$ Rate of unemployment

$L \quad$ Labour supply (employees plus unemployed)

$N \quad$ Total number of employees, annual average

$Y \quad$ Gross domestic product

$V \quad$ Vacancy rate

$C U$ Capacity utilization

$W \quad$ Gross hourly wages per employee, excluding employers' contribution to social security

$P \quad$ Deflator of gross domestic product

K Aggregate capital stock, at 1976 prices

$t_{1} \quad$ Employers' contribution to social security as a proportion of wages and salaries

$t_{2} \quad$ Workers' tax rate, including social security contributions

$t_{3} \quad$ Indirect tax rate

UP Union power; trade union membership (percentage of employees)

$H \quad$ Hours of work per employee

TH Trend value of hours of work per employee

$A \quad$ Index of labour-augmented technical progress; three-year backward moving average

$N^{*} \quad$ Desired employment emerging from the labour demand equation; see Table 2 in the text

$P C \quad$ Deflator of private consumption

$H P R \quad$ GDP per man-hour

$L U$ Percentage of unemployed who have been unemployed for over six months

$t \quad$ Time trend 


\section{BELGIUM}

The data are annual time series convering the period 1953-82. If not otherwise indicated, the series come from the MARIBEL Data Bank constructed by the Belgian Planning Office.

\begin{tabular}{|c|c|c|c|c|c|c|c|c|}
\hline & $U R$ & $\log L S$ & $\log L T$ & $\log Y T$ & $\log V S$ & $D U C$ & $\log W H / P$ & $\log K A / L S$ \\
\hline 1953 & $8 \cdot 04060$ & $1 \cdot 31098$ & $1 \cdot 22715$ & $6 \cdot 78008$ & $2 \cdot 56125$ & & $4 \cdot 36363$ & 5.60837 \\
\hline 1954 & 6.99617 & $1 \cdot 30435$ & $1 \cdot 23182$ & $6 \cdot 82023$ & $2 \cdot 51276$ & & $4 \cdot 38540$ & $5 \cdot 66632$ \\
\hline 1955 & $5 \cdot 79042$ & $1 \cdot 29973$ & $1 \cdot 24008$ & $6 \cdot 86706$ & $3 \cdot 35829$ & & 4.43269 & $5 \cdot 72610$ \\
\hline 1956 & $4 \cdot 71522$ & $1 \cdot 29956$ & $1 \cdot 25126$ & 6.89398 & $3 \cdot 32370$ & & $4 \cdot 46291$ & $5 \cdot 78568$ \\
\hline 1957 & $3 \cdot 85778$ & $1 \cdot 30210$ & $1 \cdot 26276$ & 6.91361 & $3 \cdot 23884$ & & $4 \cdot 52570$ & $5 \cdot 82712$ \\
\hline 1958 & $5 \cdot 84812$ & $1 \cdot 29984$ & $1 \cdot 23958$ & 6.91084 & $2 \cdot 25612$ & & $4 \cdot 55796$ & $5 \cdot 86272$ \\
\hline 1959 & $6 \cdot 50527$ & $1 \cdot 28537$ & $1 \cdot 21810$ & 6.94041 & $1 \cdot 72669$ & & $4 \cdot 59057$ & $5 \cdot 92022$ \\
\hline 1960 & $5 \cdot 00181$ & $1 \cdot 28307$ & $1 \cdot 23176$ & 6.99251 & $2 \cdot 64546$ & & $4 \cdot 61371$ & 5.97287 \\
\hline 1961 & 3.97636 & $1 \cdot 28429$ & $1 \cdot 24371$ & $7 \cdot 04035$ & $3 \cdot 25721$ & & $4 \cdot 66137$ & 6.03006 \\
\hline 1962 & $3 \cdot 42480$ & $1 \cdot 29429$ & $1 \cdot 25944$ & $7 \cdot 09251$ & $3 \cdot 30487$ & & $4 \cdot 70351$ & 8645 \\
\hline 1963 & $3 \cdot 36710$ & $1 \cdot 29229$ & $1 \cdot 25803$ & $7 \cdot 13480$ & $3 \cdot 53736$ & $81 \cdot 30$ & $4 \cdot 75054$ & $6 \cdot 14929$ \\
\hline 1964 & $2 \cdot 46191$ & $1 \cdot 29662$ & $1 \cdot 27169$ & $7 \cdot 20189$ & $3 \cdot 25902$ & $83 \cdot 80$ & $4 \cdot 82551$ & $6 \cdot 20369$ \\
\hline 1965 & $3 \cdot 07636$ & $1 \cdot 29937$ & $1 \cdot 26813$ & $7 \cdot 23761$ & $2 \cdot 80808$ & $81 \cdot 87$ & $4 \cdot 87545$ & $6 \cdot 25563$ \\
\hline 1966 & $3 \cdot 05839$ & $1 \cdot 30185$ & $1 \cdot 27079$ & $7 \cdot 26584$ & $2 \cdot 71158$ & $82 \cdot 27$ & 4.93879 & $\cdot 31739$ \\
\hline 1967 & 3.94967 & $1 \cdot 30513$ & $1 \cdot 26483$ & $7 \cdot 30463$ & $2 \cdot 09013$ & $78 \cdot 27$ & 4.99512 & $5 \cdot 37611$ \\
\hline 1968 & $4 \cdot 26814$ & $1 \cdot 30825$ & $1 \cdot 26463$ & $7 \cdot 34461$ & $2 \cdot 16585$ & 78.97 & $5 \cdot 02785$ & $6 \cdot 42746$ \\
\hline 1969 & $3 \cdot 55346$ & $1 \cdot 31871$ & $1 \cdot 28253$ & $7 \cdot 40360$ & $3 \cdot 18672$ & $86 \cdot 00$ & $5 \cdot 06523$ & $6 \cdot 47278$ \\
\hline 1970 & $3 \cdot 03891$ & $1 \cdot 32917$ & $1 \cdot 29831$ & $7 \cdot 46280$ & $3 \cdot 39746$ & $86 \cdot 27$ & $5 \cdot 14221$ & $6 \cdot 52201$ \\
\hline 1971 & $3 \cdot 28906$ & $1 \cdot 33960$ & $1 \cdot 30615$ & $7 \cdot 50327$ & $2 \cdot 70511$ & 83.67 & $5 \cdot 21535$ & $5 \cdot 57245$ \\
\hline 1972 & $3 \cdot 73853$ & $1 \cdot 34422$ & $1 \cdot 30612$ & $7 \cdot 55627$ & $2 \cdot 20915$ & $82 \cdot 70$ & $5 \cdot 30638$ & 62423 \\
\hline 1973 & $3 \cdot 82085$ & $1 \cdot 35810$ & $1 \cdot 31914$ & $7 \cdot 61660$ & $2 \cdot 74148$ & $84 \cdot 70$ & $5 \cdot 37112$ & $6 \cdot 66210$ \\
\hline 1974 & $4 \cdot 31306$ & $1 \cdot 37539$ & $1 \cdot 33130$ & $7 \cdot 66037$ & $2 \cdot 90570$ & $83 \cdot 27$ & $5 \cdot 45611$ & $6 \cdot 69598$ \\
\hline 1975 & $7 \cdot 50164$ & $1 \cdot 38354$ & $1 \cdot 30556$ & $7 \cdot 63992$ & $1 \cdot 43818$ & $72 \cdot 23$ & $5 \cdot 57045$ & $6 \cdot 73135$ \\
\hline 1976 & $8 \cdot 47584$ & $1 \cdot 39265$ & $1 \cdot 30408$ & $7 \cdot 69484$ & 1.49178 & $75 \cdot 13$ & $5 \cdot 62191$ & $6 \cdot 75911$ \\
\hline 1977 & $9 \cdot 82973$ & $1 \cdot 40116$ & $1 \cdot 29769$ & $7 \cdot 70202$ & $1 \cdot 39252$ & $73 \cdot 07$ & $5 \cdot 66303$ & $5 \cdot 78322$ \\
\hline 1978 & $10 \cdot 55616$ & $1 \cdot 40801$ & $1 \cdot 29645$ & $7 \cdot 73428$ & 1.49335 & $73 \cdot 25$ & $5 \cdot 69051$ & $6 \cdot 80729$ \\
\hline 1979 & 10.96395 & 1.42377 & $1 \cdot 30765$ & $7 \cdot 75687$ & $1 \cdot 82729$ & $77 \cdot 25$ & $5 \cdot 72257$ & $6 \cdot 82320$ \\
\hline 1980 & $11 \cdot 94510$ & 1.43019 & $1 \cdot 30298$ & $7 \cdot 79194$ & 1.98389 & $76 \cdot 20$ & $5 \cdot 77785$ & $6 \cdot 85310$ \\
\hline 1981 & $14 \cdot 32945$ & 1.43267 & $1 \cdot 27801$ & $7 \cdot 78273$ & $1 \cdot 56381$ & $75 \cdot 10$ & $5 \cdot 83137$ & $6 \cdot 87889$ \\
\hline 982 & 2 & 234 & $1 \cdot 26863$ & $7 \cdot 79465$ & 918 & $6 \cdot 05$ & $5 \cdot 83477$ & נט \\
\hline
\end{tabular}




\begin{tabular}{|c|c|c|c|c|c|c|c|c|}
\hline & $\log I P C$ & $\Delta \log W H$ & $\Delta \log P$ & $\log U_{p}$ & $T 1$ & $T 2$ & $T 3$ & $D U R$ \\
\hline 1953 & $3 \cdot 94606$ & & & $5 \cdot 40668$ & 0.09860 & $0 \cdot 12906$ & 0.05434 & \\
\hline 1954 & 3.95045 & 0.02762 & 0.00584 & $5 \cdot 47890$ & 0.09890 & $0 \cdot 12139$ & 0.05253 & \\
\hline 1955 & 3.96249 & 0.05440 & $0 \cdot 00711$ & $6 \cdot 26137$ & $0 \cdot 10246$ & $0 \cdot 12634$ & 0.05770 & \\
\hline 1956 & 3.94288 & 0.06546 & 0.03524 & $6 \cdot 19443$ & $0 \cdot 10379$ & $0 \cdot 12630$ & $0 \cdot 05045$ & \\
\hline 1957 & $3 \cdot 87936$ & $0 \cdot 10064$ & 0.03785 & $7 \cdot 55669$ & $0 \cdot 11036$ & $0 \cdot 13311$ & 0.05997 & $64 \cdot 72$ \\
\hline 1958 & $3 \cdot 88461$ & 0.04245 & $0 \cdot 01019$ & $5 \cdot 01086$ & $0 \cdot 10926$ & $0 \cdot 12981$ & 0.06000 & $71 \cdot 87$ \\
\hline 1959 & $3 \cdot 89791$ & 0.03158 & -0.00104 & $6 \cdot 24104$ & $0 \cdot 10662$ & $0 \cdot 13530$ & 0.05987 & $49 \cdot 66$ \\
\hline 1960 & $3 \cdot 89446$ & 0.02860 & 0.00547 & $5 \cdot 14927$ & $0 \cdot 11125$ & $0 \cdot 13023$ & 0.06014 & $64 \cdot 00$ \\
\hline 1961 & $3 \cdot 87739$ & 0.05272 & 0.00505 & $3 \cdot 83667$ & $0 \cdot 11787$ & $0 \cdot 13714$ & 0.06637 & $50 \cdot 75$ \\
\hline 1962 & $3 \cdot 88236$ & 0.05764 & 0.01550 & $4 \cdot 89055$ & $0 \cdot 11693$ & $0 \cdot 14533$ & $0 \cdot 06872$ & $55 \cdot 78$ \\
\hline 1963 & $3 \cdot 86846$ & 0.07605 & 0.02903 & $4 \cdot 78001$ & $0 \cdot 12531$ & $0 \cdot 14708$ & 0.06942 & $56 \cdot 53$ \\
\hline 1964 & $3 \cdot 84654$ & $0 \cdot 12137$ & 0.04639 & $5 \cdot 33325$ & $0 \cdot 13093$ & $0 \cdot 14530$ & 0.07166 & $47 \cdot 84$ \\
\hline 1965 & $3 \cdot 83171$ & $0 \cdot 10185$ & $0 \cdot 05191$ & 3.47380 & $0 \cdot 13730$ & $0 \cdot 15258$ & 0.07217 & $31 \cdot 82$ \\
\hline 1966 & $3 \cdot 80441$ & 0.09599 & 0.03265 & $5 \cdot 50679$ & $0 \cdot 13990$ & $0 \cdot 16292$ & 0.08354 & $35 \cdot 77$ \\
\hline 1967 & $3 \cdot 77500$ & $0 \cdot 08404$ & $0 \cdot 02771$ & 4.43232 & $0 \cdot 14052$ & $0 \cdot 16957$ & 0.08657 & $32 \cdot 61$ \\
\hline 1968 & $3 \cdot 78841$ & 0.06389 & 0.03116 & $5 \cdot 12867$ & $0 \cdot 14150$ & $0 \cdot 18246$ & 0.08757 & $46 \cdot 83$ \\
\hline 1969 & $3 \cdot 78730$ & 0.08444 & 0.04706 & $4 \cdot 30735$ & $0 \cdot 14373$ & $0 \cdot 18857$ & 0.08839 & $33 \cdot 24$ \\
\hline 1970 & $3 \cdot 76747$ & $0 \cdot 12556$ & 0.04858 & $6 \cdot 48446$ & $0 \cdot 15303$ & $0 \cdot 20224$ & 0.08839 & $35 \cdot 36$ \\
\hline 1971 & $3 \cdot 70559$ & $0 \cdot 12535$ & 0.05221 & $6 \cdot 32472$ & $0 \cdot 15739$ & $0 \cdot 20813$ & 0.08919 & $37 \cdot 35$ \\
\hline 1972 & $3 \cdot 74191$ & $0 \cdot 15965$ & 0.06862 & $5 \cdot 09122$ & $0 \cdot 16089$ & $0 \cdot 21564$ & $0 \cdot 82280$ & $32 \cdot 66$ \\
\hline 1973 & $3 \cdot 90759$ & $0 \cdot 13628$ & $0 \cdot 07154$ & $5 \cdot 99667$ & $0 \cdot 16217$ & $0 \cdot 22657$ & $0 \cdot 08101$ & $44 \cdot 55$ \\
\hline 1974 & $3 \cdot 78498$ & $0 \cdot 19921$ & $0 \cdot 11422$ & $5 \cdot 54531$ & $0 \cdot 15985$ & $0 \cdot 24542$ & 0.08365 & $47 \cdot 05$ \\
\hline 1975 & $3 \cdot 73895$ & $0 \cdot 23821$ & $0 \cdot 12388$ & $5 \cdot 60908$ & $0 \cdot 16717$ & $0 \cdot 27733$ & 0.07641 & $42 \cdot 75$ \\
\hline 1976 & $3 \cdot 68667$ & $0 \cdot 12062$ & 0.06916 & 6.02095 & $0 \cdot 16223$ & $0 \cdot 27166$ & $0 \cdot 08427$ & $59 \cdot 64$ \\
\hline 1977 & $3 \cdot 61526$ & $0 \cdot 11054$ & 0.06941 & $5 \cdot 72256$ & $0 \cdot 16613$ & $0 \cdot 29424$ & $0 \cdot 08491$ & $65 \cdot 50$ \\
\hline 1978 & $3 \cdot 66646$ & 0.06749 & 0.04002 & $6 \cdot 15752$ & $0 \cdot 16062$ & $0 \cdot 31142$ & 0.08834 & $69 \cdot 00$ \\
\hline 1979 & $3 \cdot 72246$ & 0.07736 & 0.04530 & $5 \cdot 68407$ & $0 \cdot 16131$ & $0 \cdot 32009$ & 0.08809 & $71 \cdot 78$ \\
\hline 1980 & $3 \cdot 83745$ & 0.08906 & 0.03378 & $4 \cdot 66070$ & $0 \cdot 16056$ & $0 \cdot 31562$ & 0.08638 & $70 \cdot 59$ \\
\hline 1981 & $3 \cdot 89966$ & $0 \cdot 10279$ & 0.04928 & $5 \cdot 47812$ & $0 \cdot 15386$ & $0 \cdot 32078$ & 0.09173 & 69.99 \\
\hline 1982 & $3 \cdot 87803$ & $0 \cdot 06842$ & 0.06502 & $5 \cdot 41946$ & $0 \cdot 14510$ & $0 \cdot 34911$ & 0.08979 & $73 \cdot 56$ \\
\hline
\end{tabular}




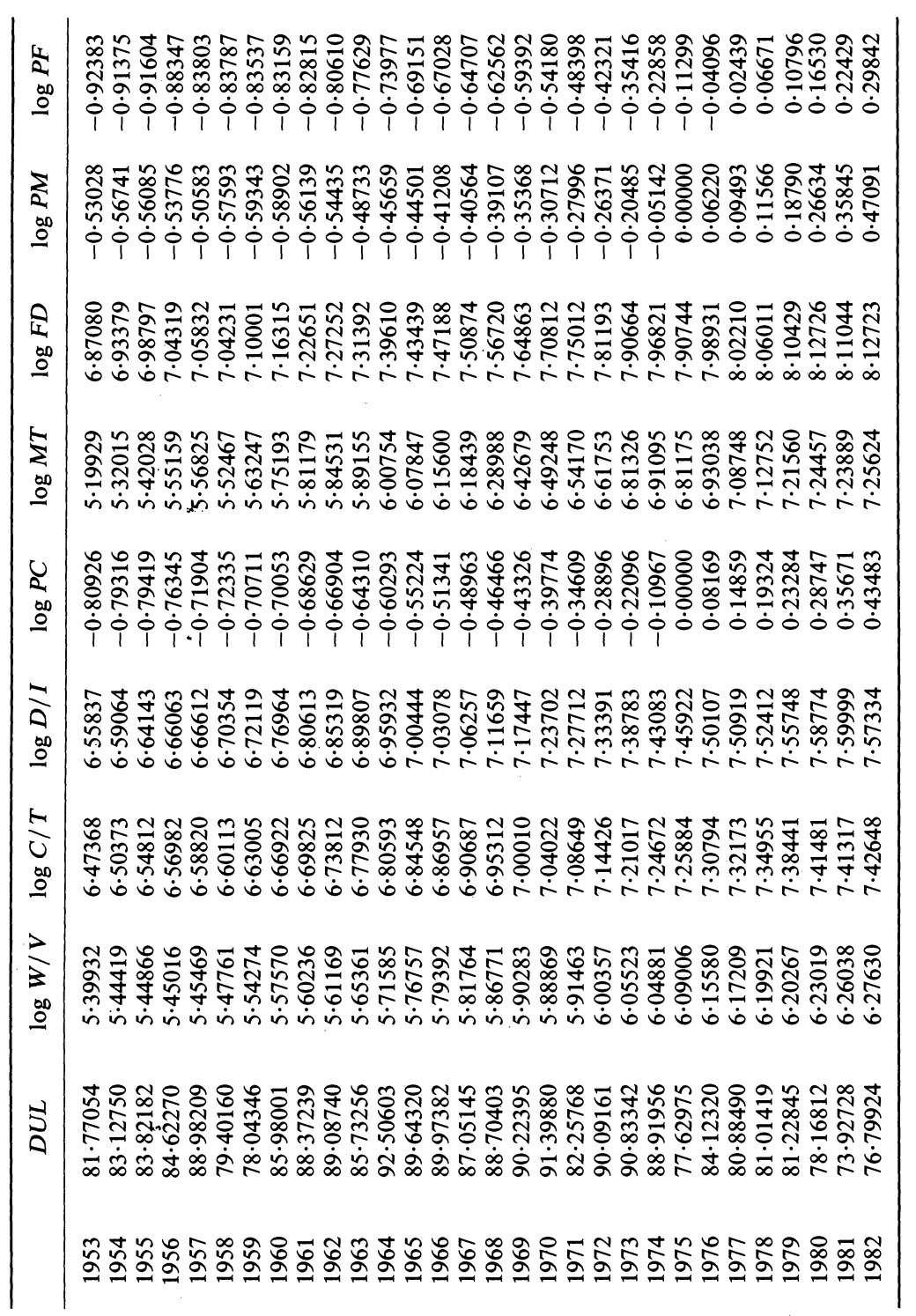




\begin{tabular}{|c|c|}
\hline$\frac{Q}{\alpha}$ & 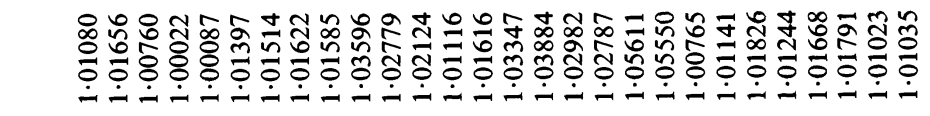 \\
\hline$\underset{\substack{\infty \\
0}}{\circledR}$ & 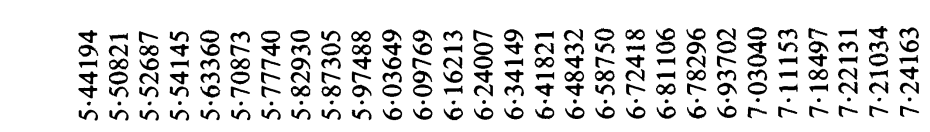 \\
\hline $\begin{array}{l}0 \\
0 \\
0\end{array}$ & 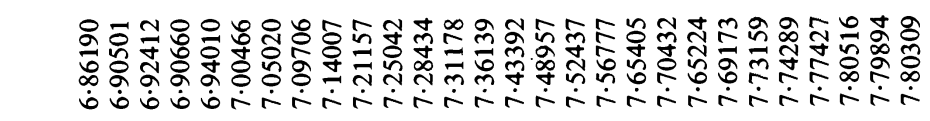 \\
\hline$\sum_{0}^{\infty}$ & 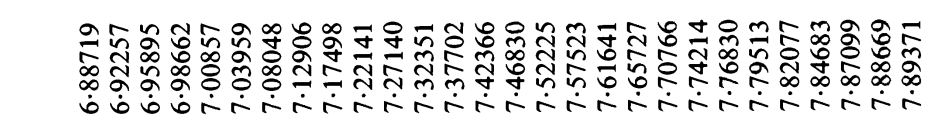 \\
\hline$\underset{\substack{2 \\
ٍ}}{\infty}$ & 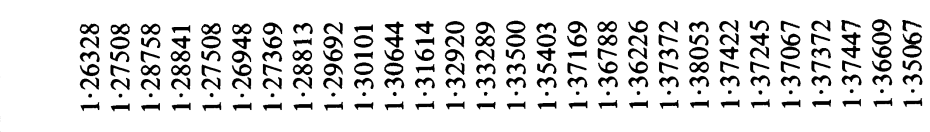 \\
\hline $\begin{array}{l}\bar{\Sigma} \\
\stackrel{0}{0}\end{array}$ & 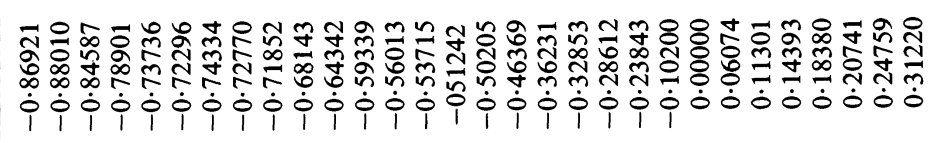 \\
\hline $\begin{array}{l}2 \\
0 \\
0\end{array}$ & 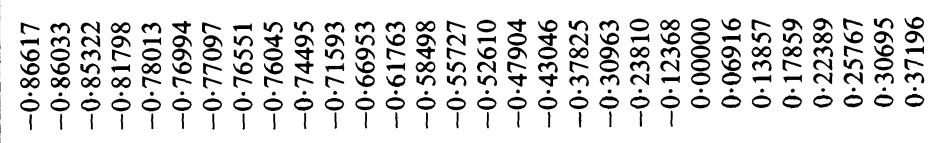 \\
\hline $\begin{array}{l}3 \\
2 \\
0\end{array}$ & 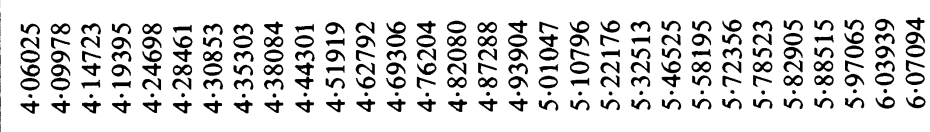 \\
\hline $\begin{array}{l}\geq \\
0 \\
0\end{array}$ & 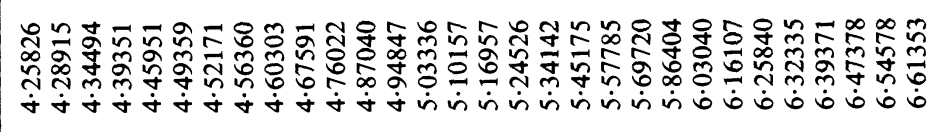 \\
\hline & 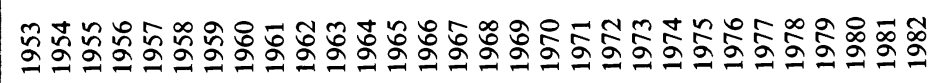 \\
\hline
\end{tabular}


$U R \quad$ Unemployment rate $=100 *(L S-L T) / L S$

$L S \quad$ Labour force (millions of workers) $=L T+$ unemployment (including partial unemployment and unemployed occupied by public sector; homogeneous series constructed by Schuttringer and Tollet at the Belgian Planning Office)

LT Total employment (millions of workers), excluding the partially unemployed and the unemployed employed by public sector

$Y T \quad$ GDP at factor cost (1975 Bfr billions)

VS Vacancies (thousands of workers, annual average) (Source: IRES, Université Catholique de Louvain)

DUC Degree of utilization of production capacities (Source: Banque Nationale de Belgique)

WH Labour cost per hour in the private sector (Bfrs per hour)

$P \quad$ GDP deflator (factor cost)

KA Capital stock, excluding dwellings (1975 Bfr billions) (Source: Bureau du Plan., note (84) TdB/3445/4389)

IPC Index of price competitiveness: world export prices (excluding energy) in Bfrs (at the $\mathrm{Bfr} / \$$ current exchange rate), relative to domestic final demand prices net of indirect taxes.

$U_{p} \quad$ Number of working days lost owing to strikes, per 1000 employees (Source: INS, Bruxelles, and Y. Leruth, Mémoire de Licence et Maîtrise en Sciences Economiques)

$T 1 \quad$ Employers' employment tax (employers' social security contributions relative to employees' gross income)

T2 Workers' tax rate (direct taxes + social security contributions)

T3 Indirect tax rate

DUR Duration of unemployment $=\%$ of unemployed for over six months (category: fully unemployed of normal aptitude) (Source: ONEM and IRES, Université Catholique de Louvain)

$D U L \quad$ Degree of utilization of labour $=100 *\{1=10 *($ partial unemployment $) / L T\}$. (Source: INS and MARIBEL)

$W / V$ Labour cost per employee relative to the price of investment goods (Bfr thousands)

$C T \quad$ Private consumption at constant prices (1975 Bfr billions)

DI Households' real disposable income (1975 Bfr billions)

$P C \quad$ Private consumption price index.

MT Imports of goods and services, excluding energy (1975 Bfr billions)

$F D$ Private consumption + investment + exports of goods (excluding energy) at constant prices (1975 Bfr billions)

$P M \quad$ Price index of imported goods and services (excluding energy); beginning of the period, data reconstructed by assuming same rate of growth as total imports

$P F \quad$ Price index of domestic final demand, net of taxes

$W \quad$ Wage cost per employee in the private sector (Bfr thousands per year)

$W N \quad$ Net wage per employee in the private sector (Bfr thousands per year)

$P I \quad$ Price index of gross fixed capital formation in the private sector

$L P \quad$ Estimated potential employment level (millions of workers)

YP Estimated potential output level (1975 $\mathrm{Bfr}$ billions)

$Y D \quad$ Estimated demand for domestic goods (1975 Bfr billions) $=Y T+M T-M D$

$M D \quad$ Estimated structural demand for non-energy imports (1975 $\mathrm{Bfr}$ billions)

RED Estimated rate of excess demand

Time $\quad 1=1953,30=1982$. 
FrANCE

\begin{tabular}{lccccccc}
\hline & $U$ & $l$ & $n t$ & $n b$ & $y t$ & $y b$ & $d d$ \\
\hline 1963 & $2 \cdot 07$ & $9 \cdot 917$ & $9 \cdot 896$ & $9 \cdot 725$ & $13 \cdot 198$ & $13 \cdot 062$ & $12 \cdot 033$ \\
1964 & $1 \cdot 86$ & $9 \cdot 926$ & $9 \cdot 907$ & $9 \cdot 739$ & $13 \cdot 262$ & $13 \cdot 130$ & $12 \cdot 131$ \\
1965 & $2 \cdot 05$ & $9 \cdot 931$ & $9 \cdot 910$ & $9 \cdot 742$ & $13 \cdot 308$ & $13 \cdot 180$ & $12 \cdot 213$ \\
1966 & $2 \cdot 08$ & $9 \cdot 938$ & $9 \cdot 918$ & $9 \cdot 747$ & $13 \cdot 359$ & $13 \cdot 236$ & $12 \cdot 272$ \\
1967 & $2 \cdot 37$ & $9 \cdot 944$ & $9 \cdot 920$ & $9 \cdot 748$ & $13 \cdot 405$ & $13 \cdot 283$ & $12 \cdot 330$ \\
1968 & $2 \cdot 61$ & $9 \cdot 944$ & $9 \cdot 917$ & $9 \cdot 742$ & $13 \cdot 447$ & $13 \cdot 324$ & $12 \cdot 373$ \\
1969 & $2 \cdot 26$ & $9 \cdot 955$ & $9 \cdot 932$ & $9 \cdot 757$ & $13 \cdot 514$ & $13 \cdot 396$ & $12 \cdot 430$ \\
1970 & $2 \cdot 43$ & $9 \cdot 971$ & $9 \cdot 946$ & $9 \cdot 769$ & $13 \cdot 570$ & $13 \cdot 455$ & $12 \cdot 474$ \\
1971 & $2 \cdot 67$ & $9 \cdot 978$ & $9 \cdot 951$ & $9 \cdot 772$ & $13 \cdot 623$ & $13 \cdot 510$ & $12 \cdot 527$ \\
1972 & $2 \cdot 77$ & $9 \cdot 985$ & $9 \cdot 957$ & $9 \cdot 777$ & $13 \cdot 680$ & $13 \cdot 571$ & $12 \cdot 584$ \\
1973 & $2 \cdot 65$ & $9 \cdot 997$ & $9 \cdot 970$ & $9 \cdot 790$ & $13 \cdot 732$ & $13 \cdot 627$ & $12 \cdot 654$ \\
1974 & $2 \cdot 83$ & $10 \cdot 008$ & $9 \cdot 979$ & $9 \cdot 798$ & $13 \cdot 764$ & $13 \cdot 661$ & $12 \cdot 694$ \\
1975 & $4 \cdot 08$ & $10 \cdot 013$ & $9 \cdot 971$ & $9 \cdot 785$ & $13 \cdot 766$ & $13 \cdot 661$ & $12 \cdot 794$ \\
1976 & $4 \cdot 39$ & $10 \cdot 023$ & $9 \cdot 978$ & $9 \cdot 789$ & $13 \cdot 816$ & $13 \cdot 710$ & $12 \cdot 831$ \\
1977 & $4 \cdot 90$ & $10 \cdot 037$ & $9 \cdot 986$ & $9 \cdot 795$ & $13 \cdot 846$ & $13 \cdot 742$ & $12 \cdot 867$ \\
1978 & $5 \cdot 23$ & $10 \cdot 044$ & $9 \cdot 990$ & $9 \cdot 796$ & $13 \cdot 883$ & $13 \cdot 780$ & $12 \cdot 930$ \\
1979 & $5 \cdot 91$ & $10 \cdot 052$ & $9 \cdot 991$ & $9 \cdot 795$ & $13 \cdot 916$ & $13 \cdot 815$ & $12 \cdot 976$ \\
1980 & $6 \cdot 30$ & $10 \cdot 057$ & $9 \cdot 991$ & $9 \cdot 794$ & $13 \cdot 926$ & $13 \cdot 825$ & $12 \cdot 995$ \\
1981 & $7 \cdot 37$ & $10 \cdot 063$ & $9 \cdot 986$ & $9 \cdot 783$ & $13 \cdot 931$ & $13 \cdot 829$ & $13 \cdot 028$ \\
1982 & $8 \cdot 10$ & $10 \cdot 072$ & $9 \cdot 987$ & $9 \cdot 780$ & $13 \cdot 949$ & $13 \cdot 847$ & $13 \cdot 074$ \\
1983 & $8 \cdot 30$ & $10 \cdot 069$ & $9 \cdot 982$ & $9 \cdot 769$ & $13 \cdot 956$ & $13 \cdot 855$ & $13 \cdot 088$ \\
1984 & $9 \cdot 76$ & $10 \cdot 075$ & $9 \cdot 972$ & $9 \cdot 754$ & $13 \cdot 969$ & $13 \cdot 870$ & $13 \cdot 098$ \\
\hline
\end{tabular}

\begin{tabular}{rcccccccr}
\hline & $w d$ & $k$ & $z_{1}$ & $\omega$ & $w$ & $k-n t$ & $\varphi$ & $\pi$ \\
\hline 1963 & $3 \cdot 965$ & $13 \cdot 464$ & $84 \cdot 8$ & $4 \cdot 208$ & $2 \cdot 010$ & $3 \cdot 567$ & $0 \cdot 908$ & $5 \cdot 8$ \\
1964 & $4 \cdot 047$ & $13 \cdot 515$ & $84 \cdot 3$ & $4 \cdot 178$ & $2 \cdot 063$ & $3 \cdot 607$ & $0 \cdot 869$ & $4 \cdot 2$ \\
1965 & $4 \cdot 129$ & $13 \cdot 565$ & $82 \cdot 7$ & $4 \cdot 142$ & $2 \cdot 109$ & $3 \cdot 654$ & $0 \cdot 855$ & $2 \cdot 8$ \\
1966 & $4 \cdot 207$ & $13 \cdot 619$ & $83 \cdot 7$ & $4 \cdot 178$ & $2 \cdot 146$ & $3 \cdot 701$ & $0 \cdot 841$ & $2 \cdot 5$ \\
1967 & $4 \cdot 243$ & $13 \cdot 672$ & $82 \cdot 9$ & $4 \cdot 225$ & $2 \cdot 191$ & $3 \cdot 751$ & $0 \cdot 829$ & $1 \cdot 4$ \\
1968 & $4 \cdot 371$ & $13 \cdot 725$ & $83 \cdot 5$ & $4 \cdot 601$ & $2 \cdot 260$ & $3 \cdot 807$ & $0 \cdot 953$ & $3 \cdot 6$ \\
1969 & $4 \cdot 496$ & $13 \cdot 784$ & $86 \cdot 5$ & $4 \cdot 605$ & $2 \cdot 311$ & $3 \cdot 851$ & $1 \cdot 017$ & $3 \cdot 9$ \\
1970 & $4 \cdot 605$ & $13 \cdot 843$ & $86 \cdot 1$ & $4 \cdot 605$ & $2 \cdot 370$ & $3 \cdot 896$ & $1 \cdot 000$ & $2 \cdot 4$ \\
1971 & $4 \cdot 662$ & $13 \cdot 903$ & $85 \cdot 8$ & $4 \cdot 732$ & $2 \cdot 436$ & $3 \cdot 952$ & $0 \cdot 992$ & $4 \cdot 0$ \\
1972 & $4 \cdot 760$ & $13 \cdot 963$ & $86 \cdot 1$ & $4 \cdot 807$ & $2 \cdot 486$ & $4 \cdot 006$ & $0 \cdot 994$ & $4 \cdot 8$ \\
1973 & $4 \cdot 912$ & $14 \cdot 022$ & $88 \cdot 1$ & $4 \cdot 953$ & $2 \cdot 549$ & $4 \cdot 052$ & $1 \cdot 030$ & $6 \cdot 3$ \\
1974 & $5 \cdot 005$ & $14 \cdot 076$ & $85 \cdot 4$ & $5 \cdot 050$ & $2 \cdot 623$ & $4 \cdot 096$ & $1 \cdot 066$ & $3 \cdot 9$ \\
1975 & $4 \cdot 993$ & $14 \cdot 119$ & $78 \cdot 8$ & $5 \cdot 288$ & $2 \cdot 689$ & $4 \cdot 148$ & $1 \cdot 087$ & $6 \cdot 1$ \\
1976 & $5 \cdot 107$ & $14 \cdot 165$ & $82 \cdot 9$ & $5 \cdot 079$ & $2 \cdot 741$ & $4 \cdot 186$ & $1 \cdot 083$ & $4 \cdot 0$ \\
1977 & $5 \cdot 163$ & $14 \cdot 207$ & $83 \cdot 6$ & $4 \cdot 982$ & $2 \cdot 787$ & $4 \cdot 221$ & $1 \cdot 081$ & $3 \cdot 0$ \\
1978 & $5 \cdot 236$ & $14 \cdot 249$ & $83 \cdot 4$ & $5 \cdot 043$ & $2 \cdot 823$ & $4 \cdot 258$ & $1 \cdot 085$ & $3 \cdot 8$ \\
1979 & $5 \cdot 306$ & $14 \cdot 289$ & $84 \cdot 6$ & $5 \cdot 135$ & $2 \cdot 856$ & $4 \cdot 298$ & $1 \cdot 077$ & $4 \cdot 4$ \\
1980 & $5 \cdot 363$ & $14 \cdot 332$ & $84 \cdot 8$ & $5 \cdot 096$ & $2 \cdot 886$ & $4 \cdot 340$ & $1 \cdot 078$ & $1 \cdot 1$ \\
1981 & $5 \cdot 370$ & $14 \cdot 368$ & $82 \cdot 1$ & $5 \cdot 020$ & $2 \cdot 918$ & $4 \cdot 382$ & $1 \cdot 109$ & $-1 \cdot 2$ \\
1982 & $5 \cdot 370$ & $14 \cdot 402$ & $82 \cdot 2$ & $5 \cdot 128$ & $2 \cdot 978$ & $4 \cdot 415$ & $1 \cdot 129$ & $-3 \cdot 6$ \\
1983 & $5 \cdot 385$ & $14 \cdot 432$ & $82 \cdot 0$ & $5 \cdot 097$ & $3 \cdot 005$ & $4 \cdot 449$ & $1 \cdot 141$ & $-1 \cdot 6$ \\
1984 & $5 \cdot 462$ & $14 \cdot 458$ & $82 \cdot 0$ & $4 \cdot 968$ & $3 \cdot 017$ & $4 \cdot 485$ & $1 \cdot 162$ & $-2 \cdot 4$ \\
\hline
\end{tabular}




\begin{tabular}{rrrrrrc}
\hline & \multicolumn{1}{c}{$\gamma$} & $\dot{w}$ & $\dot{p}$ & $t_{1}$ & \multicolumn{1}{c}{$t_{2}$} & $t_{3}$ \\
\hline 1963 & $78 \cdot 06$ & $9 \cdot 66$ & $6 \cdot 21$ & $24 \cdot 18$ & $5 \cdot 53$ & $18 \cdot 19$ \\
1964 & $78 \cdot 70$ & $9 \cdot 10$ & $4 \cdot 06$ & $24 \cdot 18$ & $5 \cdot 74$ & $18 \cdot 49$ \\
1965 & $79 \cdot 40$ & $6 \cdot 32$ & $2 \cdot 69$ & $24 \cdot 71$ & $5 \cdot 91$ & $18 \cdot 28$ \\
1966 & $83 \cdot 36$ & $6 \cdot 25$ & $2 \cdot 85$ & $24 \cdot 65$ & $6 \cdot 14$ & $18 \cdot 35$ \\
1967 & $83 \cdot 82$ & $6 \cdot 58$ & $3 \cdot 13$ & $25 \cdot 30$ & $6 \cdot 36$ & $17 \cdot 77$ \\
1968 & $81 \cdot 25$ & $10 \cdot 71$ & $4 \cdot 16$ & $24 \cdot 75$ & $6 \cdot 48$ & $17 \cdot 50$ \\
1969 & $88 \cdot 77$ & $10 \cdot 80$ & $6 \cdot 36$ & $22 \cdot 72$ & $6 \cdot 87$ & $18 \cdot 07$ \\
1970 & $100 \cdot 00$ & $11 \cdot 43$ & $5 \cdot 47$ & $22 \cdot 21$ & $6 \cdot 55$ & $16 \cdot 78$ \\
1971 & $102 \cdot 57$ & $11 \cdot 80$ & $5 \cdot 60$ & $22 \cdot 31$ & $6 \cdot 58$ & $16 \cdot 60$ \\
1972 & $100 \cdot 15$ & $10 \cdot 93$ & $6 \cdot 00$ & $22 \cdot 29$ & $6 \cdot 81$ & $16 \cdot 67$ \\
1973 & $95 \cdot 27$ & $13 \cdot 37$ & $7 \cdot 49$ & $22 \cdot 44$ & $6 \cdot 92$ & $16 \cdot 49$ \\
1974 & $101 \cdot 39$ & $17 \cdot 01$ & $10 \cdot 55$ & $22 \cdot 60$ & $7 \cdot 09$ & $16 \cdot 11$ \\
1975 & $90 \cdot 48$ & $16 \cdot 76$ & $12 \cdot 57$ & $24 \cdot 15$ & $7 \cdot 58$ & $15 \cdot 98$ \\
1976 & $90 \cdot 67$ & $14 \cdot 02$ & $9 \cdot 40$ & $24 \cdot 58$ & $8 \cdot 25$ & $16 \cdot 62$ \\
1977 & $97 \cdot 10$ & $12 \cdot 28$ & $8 \cdot 60$ & $25 \cdot 14$ & $8 \cdot 84$ & $15 \cdot 75$ \\
1978 & $97 \cdot 01$ & $11 \cdot 98$ & $9 \cdot 04$ & $25 \cdot 56$ & $8 \cdot 94$ & $16 \cdot 16$ \\
1979 & $93 \cdot 67$ & $12 \cdot 43$ & $9 \cdot 91$ & $26 \cdot 01$ & $10 \cdot 35$ & $16 \cdot 82$ \\
1980 & $90 \cdot 97$ & $14 \cdot 04$ & $11 \cdot 51$ & $26 \cdot 16$ & $11 \cdot 34$ & $16 \cdot 87$ \\
1981 & $91 \cdot 10$ & $14 \cdot 07$ & $11 \cdot 15$ & $26 \cdot 13$ & $10 \cdot 97$ & $16 \cdot 83$ \\
1982 & $93 \cdot 82$ & $16 \cdot 90$ & $11 \cdot 90$ & $26 \cdot 73$ & $11 \cdot 71$ & $17 \cdot 11$ \\
1983 & $96 \cdot 61$ & $10 \cdot 51$ & $9 \cdot 09$ & $27 \cdot 53$ & $12 \cdot 45$ & $17 \cdot 09$ \\
1984 & $97 \cdot 10$ & $7 \cdot 84$ & $7 \cdot 01$ & $27 \cdot 74$ & $13 \cdot 44$ & $17 \cdot 44$ \\
\hline
\end{tabular}

List of variables

All figures are annual averages. All logarithms are natural logarithms.

$U \quad$ Unemployment rate. Number of unemployed (ILO definition), divided by labour force. In per cent: Regularly published in Rapport sur les Comptes de la Nation, INSEE, or 'Banque de données DMS', INSEE. (The series was recently revised).

$l \quad \log$ labour force, in thousands, same source as above.

$n t \quad \log$ of total employment, in thousands, same source as above.

$n b \quad \log$ of employment in non-financial non-governmental activities ('emploi dans les branches marchandes'), in thousands, same source as above.

$y t \quad \log$ of gross domestic product, at 1970 prices, in millions francs, same source.

$y b \quad \log$ of output in non-financial non-governmental activities ('PIB marchand'), at 1970 prices, in millions francs, same source.

dd $\quad \log$ of domestic autonomous demand, at 1970 prices, defined as government demand for goods and services, plus gross domestic investment by households and large public corporations ('Grandes Entreprises Nationales'), plus social transfers received by households, in millions francs. Figures come from Comptes de la Nation.

wd $\quad \log$ of world demand addressed to France (weights are shares in French exports). (Index base 100 in 1970). INSEE series.

$k \quad \log$ of productive capital stock, at 1970 prices, in millions francs, INSEE series.

$z_{1} \quad$ rate of capacity utilization in industry, computed from answers to INSEE business survey (per cent). Banque de données DMS.

$\omega \quad \log$ of relative cost of labour with respect to capital. (Index base 100 in 1970). INSEE series.

$w \quad \log$ of real labour cost: hourly labour cost in non-financial non-governmental activities, in 1970 francs, deflated by price of value added in these activities ('PIB marchand'). 'Banque de données DMS', INSEE. 
$k-n t \quad \log$ capital/employment ratio. Difference between the two previously defined series.

$\varphi \quad$ ratio between the minimum wage and the average wage rate. Index base 1 in 1970. 'Banque de données DMS', INSEE.

$\pi$ profitability: measure computed in Malinvaud (1983), which is the difference between an inflation-corrected net profit rate and a real interest rate, in per cent.

$\gamma \quad$ index of competitiveness, defined as ratio of unit labour cost abroad over unit labour cost in France corrected by exchange rates changes, base 100 in 1970. 'Banque de données DMS', INSEE.

$\dot{w}$

rate of increase of the hourly wage rate in non-financial non-governmental activities, in per cent. 'Banque de données DMS', INSEE.

$\dot{p} \quad$ rate of increase of the price of value added in non-financial non-governmental activities, in per cent. 'Banque de données DMS', INSEE.

$t_{1} \quad$ employers' labour tax and social security contribution rate in non-financial non-governmental activities, as per cent of total labour cost. 'Banque de données DMS', INSEE.

$t_{2} \quad$ workers' social security contribution: compulsory social security contributions of wage earners and self employed, divided by gross wages received plus gross operating surplus of non-corporate firms (in non-financial nongovernmental activities), per cent. 'Banque de données DMS', INSEE. indirect tax rate, per cent of total value added. 'Banque de données DMS', INSEE. 


\begin{tabular}{|c|c|c|c|c|c|c|c|}
\hline & \multirow[b]{2}{*}{$\begin{array}{c}\text { Capacity } \\
\text { utilization } \\
\text { rates } \\
(\%) \\
(1)\end{array}$} & \multirow[b]{2}{*}{$\begin{array}{c}\text { Vacancies } \\
(000) \\
(2)\end{array}$} & \multirow[b]{2}{*}{$\begin{array}{l}\text { Unem- } \\
\text { ployment } \\
\text { rate } \\
(\%) \\
(3)\end{array}$} & \multirow[b]{2}{*}{$\begin{array}{c}\text { Total } \\
\text { employed } \\
\text { persons } \\
(000) \\
(4)\end{array}$} & \multicolumn{3}{|c|}{ Manufacturing sector } \\
\hline & & & & & $\begin{array}{c}\text { Capital } \\
\text { Stock } \\
\text { (million } \\
\text { DM) } \\
(5)\end{array}$ & $\begin{array}{l}\text { Employed } \\
\text { persons } \\
(6)\end{array}$ & $\begin{array}{c}\text { Employ- } \\
\text { ment- } \\
\text { capital } \\
\text { ratio } \\
(7)\end{array}$ \\
\hline 1970 & $100 \cdot 0$ & 795 & 0.7 & 26,560 & & & \\
\hline 1971 & $98 \cdot 3$ & 648 & 0.8 & 26,721 & & & \\
\hline 1972 & $97 \cdot 8$ & 546 & $1 \cdot 1$ & 26,661 & 599,183 & $8,627,962$ & $14 \cdot 400$ \\
\hline 1973 & $98 \cdot 4$ & 572 & $1 \cdot 2$ & 26,849 & 622,065 & $8,663,522$ & $13 \cdot 927$ \\
\hline 1974 & $96 \cdot 0$ & 315 & $2 \cdot 6$ & 26,497 & 639,521 & $8,434,318$ & $13 \cdot 189$ \\
\hline 1975 & $92 \cdot 1$ & 236 & $4 \cdot 7$ & 25,746 & 652,292 & $7,887,735$ & $12 \cdot 092$ \\
\hline 1976 & $95 \cdot 2$ & 235 & $4 \cdot 6$ & 25,530 & 663,030 & $7,698,499$ & $11 \cdot 611$ \\
\hline 1977 & $96 \cdot 1$ & 231 & $4 \cdot 5$ & 25,490 & 673,860 & $7,631,789$ & $11 \cdot 326$ \\
\hline 1978 & $97 \cdot 1$ & 246 & $4 \cdot 3$ & 25,644 & 683,956 & $7,583,826$ & $11 \cdot 088$ \\
\hline 1979 & $99 \cdot 2$ & 304 & $3 \cdot 8$ & 25,986 & 694,277 & $7,606,927$ & $10 \cdot 957$ \\
\hline 1980 & $98 \cdot 8$ & 308 & $3 \cdot 8$ & 26,251 & 707,028 & $7,659,343$ & $10 \cdot 833$ \\
\hline 1981 & $96 \cdot 7$ & 208 & $5 \cdot 5$ & 26,048 & 719,615 & $7,488,720$ & $10 \cdot 407$ \\
\hline 1982 & $94 \cdot 5$ & 105 & $7 \cdot 5$ & 25,572 & 729,090 & $7,225,854$ & $9 \cdot 911$ \\
\hline 1983 & $94 \cdot 6^{\mathrm{a}}$ & 76 & $9 \cdot 1$ & 25,126 & 736,501 & $6,926,939$ & $9 \cdot 405$ \\
\hline 1984 & $94 \cdot 8^{\mathrm{a}}$ & 89 & $9 \cdot 1$ & $25,000^{\mathrm{a}}$ & & $6,663,000$ & \\
\hline
\end{tabular}

${ }^{\text {a }}$ Preliminary.

b 1984 (I) and (II).

Notes:

Column
(1)
(2), (3)
(4)
(5)-(7)
(8)
(9)

(12), (13)
Capacity utilization rate $=($ actual GNP/potential GNP $) \times 100$

As registered at the labour offices; averages per year

Includes self-employed persons

Manufacturing industry and mining

Labour cost per man-hour divided by GNP deflator

Lost days arising from strikes as a fraction of total worked days, per million workers

Gross labour income, including employers' contribution to social security times $(1+$ indirect tax rate), divided by net take-home pay Defined as

$$
\sum\left|\frac{U_{i}}{U}-\frac{V_{i}}{V}\right|
$$

where $U=$ unemployed, $V=$ vacancies, $i=1, \ldots, 141$ (regions, col. (12)) and $i=1, \ldots, 327$ (occupations, col. (13)).

Percentage of unemployed who have been unemployed for over six months 


\begin{tabular}{|c|c|c|c|c|c|c|}
\hline $\begin{array}{l}\text { Real } \\
\text { labour } \\
\text { cost } \\
(\mathrm{DM}) \\
(8)\end{array}$ & $\begin{array}{l}\text { Industrial } \\
\text { disputes } \\
\text { (per } \\
\text { million } \\
\text { workers) } \\
(9)\end{array}$ & $\begin{array}{c}\text { Trade } \\
\text { union } \\
\text { membership } \\
(\%) \\
(10)\end{array}$ & $\begin{array}{c}\text { Measure } \\
\text { of tax } \\
\text { wedge } \\
(11)\end{array}$ & $\begin{array}{l}\text { Regional } \\
\text { mismatch } \\
\quad(12)\end{array}$ & $\begin{array}{l}\text { Occupational } \\
\text { mismatch } \\
\text { (13) }\end{array}$ & $\begin{array}{l}\text { Duration of } \\
\text { unemployment } \\
(\%) \\
(14)\end{array}$ \\
\hline $11 \cdot 90$ & 0.01317 & 35.93 & 1.67 & & & $23 \cdot 9$ \\
\hline $12 \cdot 45$ & $0 \cdot 36366$ & $36 \cdot 01$ & $1 \cdot 71$ & & & $22 \cdot 7$ \\
\hline $13 \cdot 18$ & 0.00928 & $36 \cdot 49$ & $1 \cdot 72$ & & & $26 \cdot 1$ \\
\hline $14 \cdot 07$ & $0 \cdot 07881$ & $36 \cdot 83$ & $1 \cdot 79$ & & & $26 \cdot 7$ \\
\hline $14 \cdot 91$ & $0 \cdot 14961$ & $38 \cdot 36$ & $1 \cdot 82$ & & & $24 \cdot 5$ \\
\hline $15 \cdot 37$ & 0.01005 & $39 \cdot 28$ & $1 \cdot 83$ & & & $36 \cdot 8$ \\
\hline $15 \cdot 76$ & $0 \cdot 07765$ & $39 \cdot 94$ & $1 \cdot 89$ & 0.359 & 0.730 & $40 \cdot 8$ \\
\hline $16 \cdot 46$ & 0.00347 & $40 \cdot 06$ & 1.91 & $0 \cdot 381$ & 0.701 & $40 \cdot 4$ \\
\hline 16.91 & 0.62599 & $40 \cdot 95$ & 1.91 & 0.443 & $0 \cdot 707$ & $41 \cdot 4$ \\
\hline $17 \cdot 39$ & 0.06986 & $40 \cdot 77$ & 1.92 & 0.457 & $0 \cdot 705$ & $39 \cdot 9$ \\
\hline $17 \cdot 90$ & 0.01834 & $40 \cdot 38$ & 1.96 & 0.438 & 0.721 & $36 \cdot 2$ \\
\hline $18 \cdot 25$ & $0 \cdot 00842$ & 40.98 & 1.97 & 0.455 & 0.713 & $38 \cdot 1$ \\
\hline $18 \cdot 18$ & 0.00221 & $41 \cdot 31$ & $2 \cdot 00$ & 0.456 & $0 \cdot 703$ & $46 \cdot 4$ \\
\hline $18 \cdot 22$ & 0.00608 & $41 \cdot 59$ & $2 \cdot 03$ & 0.422 & $0 \cdot 610$ & $54 \cdot 1$ \\
\hline $17 \cdot 74^{\mathrm{b}}$ & & & $2 \cdot 05^{b}$ & & & $55 \cdot 2$ \\
\hline
\end{tabular}

Sources:

Column

(1), (10) Sachverständigenrat zur Begutachtung der gesamtwirtschaftlichen Entwicklung, Jahresgutachten 1982-1984

(2), (3), (12), Bundesanstalt für Arbelt, Amtliche Nachrichten der Bundesanstalt

(13)

für Arbeit, current volumes

(4), (8), (10) Deutsches Institut für Wirtschaftsforschung, Sozialprodukt und Einkommenskreislauf, Vierteljährliche Volkswirtschaftliche Gesamtrechnung für die Bundesrepublik Deutschland, A 11

(5), (6)

(12), (13), (14)

E. Baumgart, R. Mehl und J. Schintke (1984), Produktionsvolumen und-potential, Produktionsfaktoren des Bergbaus und des Verarbeitenden Gewerbes in der Bundesrepublik Deutschland, Deutsches Institut für Wirtschaftsforschung, Statistische Kennziffern 26. Folge 1972-1983, p. 41 (col. 4) und p. 18 (col. 5). Employment data for 1984 means 1984 (III), taken from Sachverständigenrat zur Begutachtun der Gesamtwirtschaftlichen Entwicklung, Jahresgutachten $1984 / 85$, Table 43. Note that definition of manufacturing sector in this table differs from that in Tables 4 and 5

(9), (10), (11) Statistisches Bundesamt, Statistische Jahrbucher 1970-1984 


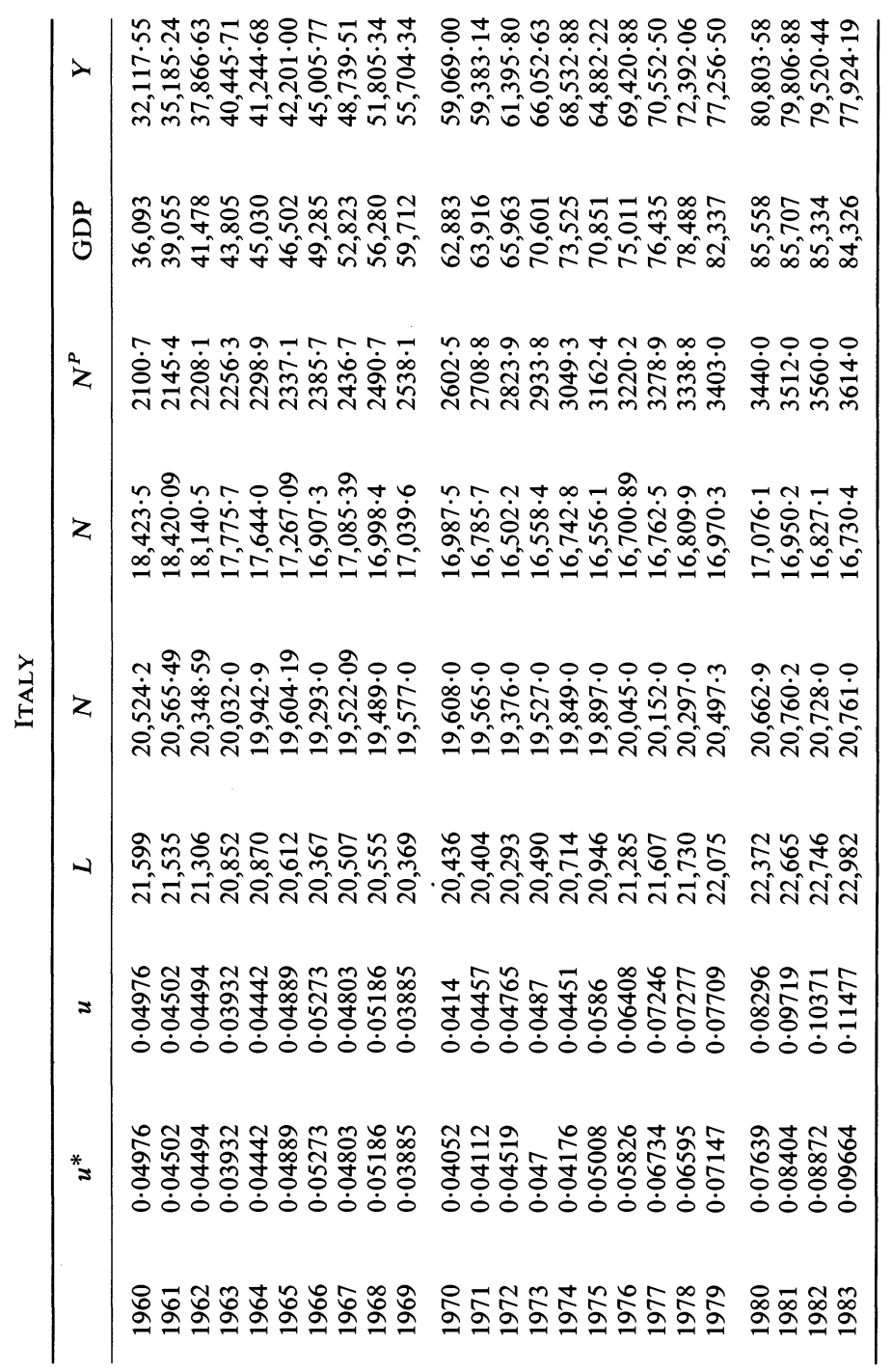




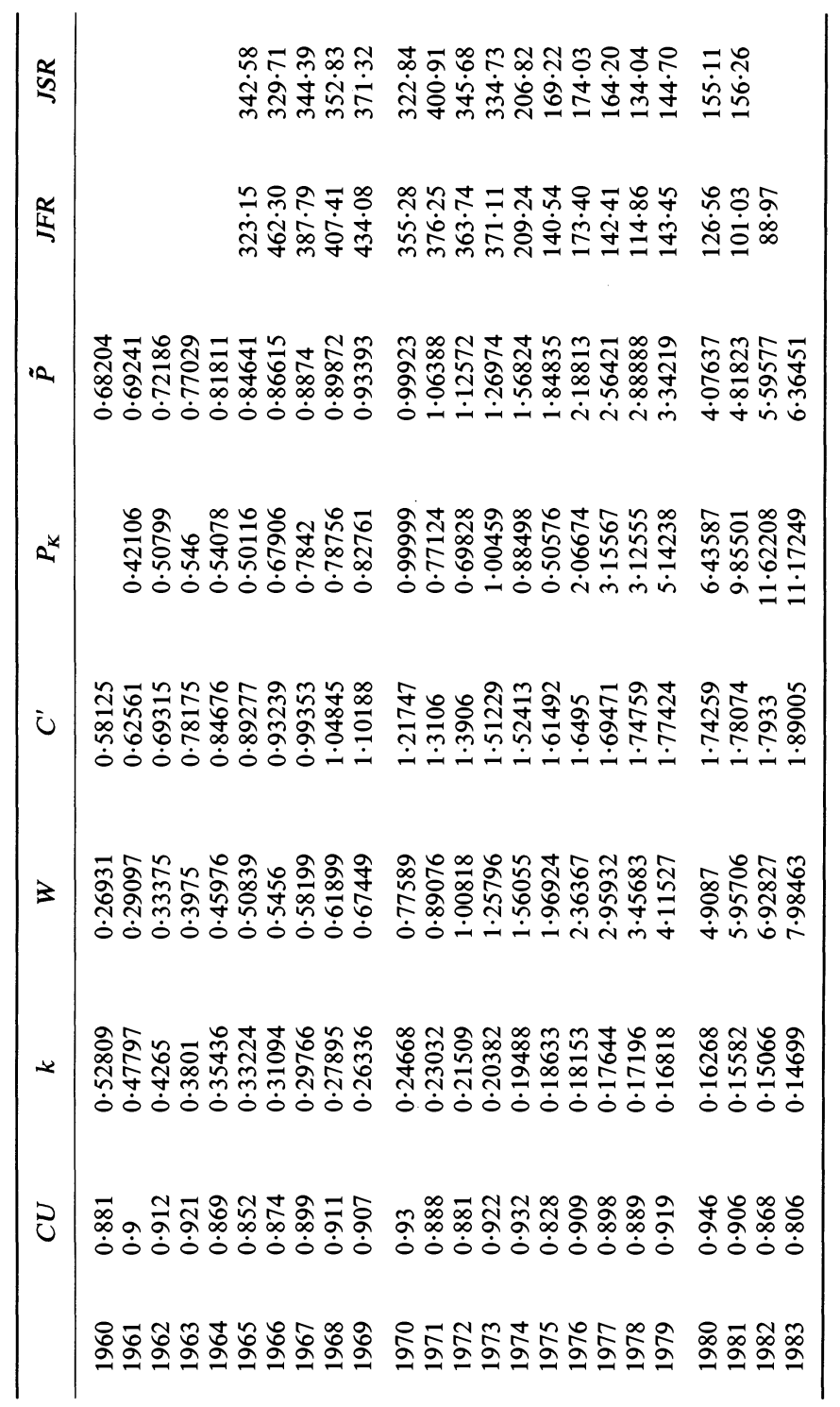




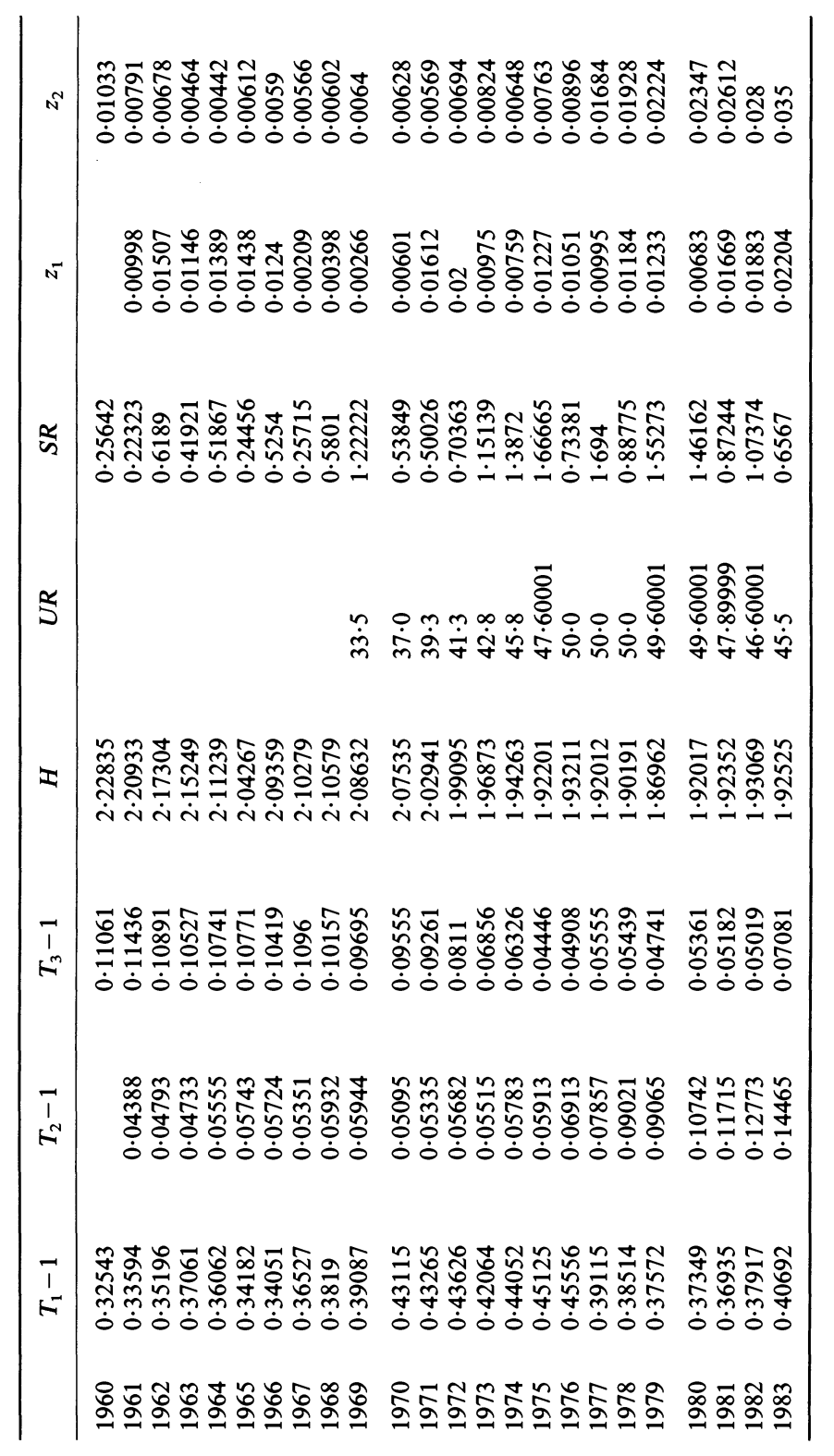




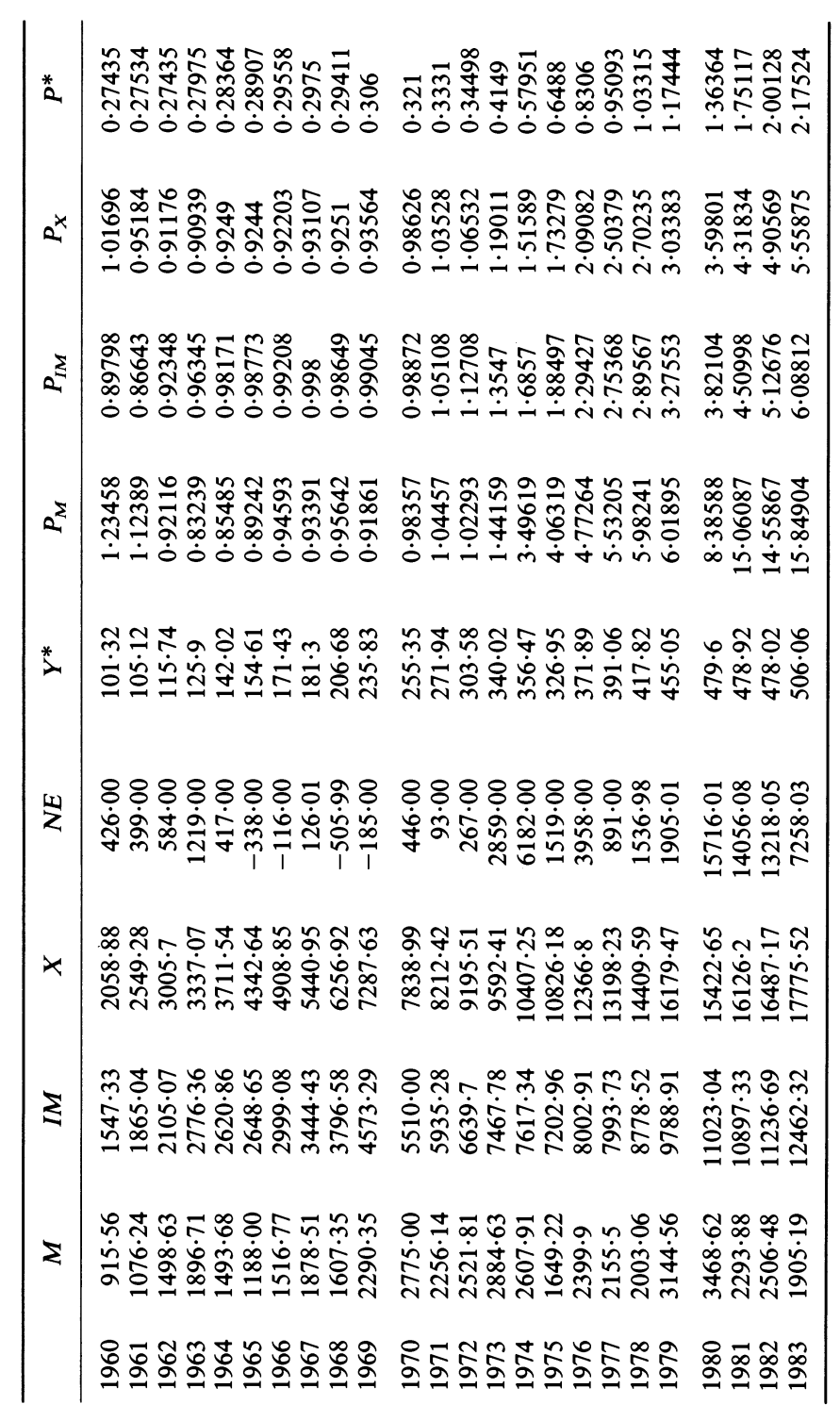




\section{Data sources and definitions}

$u^{*} \quad$ official unemployment rate (units) (ISTAT ASL)

$u$

'adjusted' unemployment rate (units). Includes dependent workers supported by the Wage Supplementation Fund. Adjustment relates only to the industrial sector ( $B I R A)$

$L \quad$ labour force (thousands of units, yearly averages). Figures include unemployed previously in employment, first job-seekers, other persons seeking employment (students, housewives, etc.) (ISTAT $A S L)$

$N^{*} \quad$ domestic (dependent and independent) total employment (thousands of units) (ISTAT ACN, ISTAT CI)

$N \quad$ 'adjusted' domestic (dependent and independent) employment in the private sector (thousands of units). Does not include dependent workers supported by the Wage Supplementation Fund. Adjustment relates only to the industrial sector (ISTAT ACN, ISTAT CI, BI RA)

employment in the public sector (thousands of units) (ISTAT ACN, ISTAT CI)

gross domestic product (1970 L billions) (ISTAT ACN, ISTAT CI)

'extended value added' of the private sector ( $1970 \mathrm{~L}$ billions). Defined as value added of the private sector plus net imports of productive inputs. All variables at market prices (ISTAT ACN, ISTAT CI, ISCO) capacity utilization rate in industry excluding construction (BI $R A)$ employment-capital ratio in the private sector. For employment see $N$; for capital stock, our calculations largely based on $R S$ hourly pre-tax wages and salaries per dependent worker (L thousands) (ISTAT ACN, ISTAT CI, PA)

$C^{\prime}$ $W T_{1} T_{3} / \tilde{P}$

$P_{K}$

$\tilde{P}$

$T_{1}-1$

user cost of capital, defined as usual. Does not include tax and other incentives, but does include a measure of capital gains implicit deflator of $Y$

tax rate on employment borne by the firm in the private sector. Includes actual and imputed contributions to social security (ISTAT ACN, ISTAT CI)

$T_{2}-1$

$T_{3}-1$

income tax rate, calculated as income taxes off disposable income (ISTAT ACN, ISTAT CI)

net indirect tax rate (indirect taxes less subsidies) in the private sector (ISTAT ACN, ISTAT CI)

$H$

$U R$ average hours worked by (dependent and independent) workers in the private sector (in thousands) $(P A)$

\section{$S R$} trade union members as a percentage of total employment. Figures refer to the three major unions (CGIL, CISL, UIL) (CER)

workers involved in industrial conflicts divided by industrial employees (ISTAT ACN, ISTAT CI, ISTAT BM)

change in non-agricultural employment structure. Defined as the sum of the changes (in absolute values) of the proportions of non-agricultural employment employed in industry, excluding construction, construction industry, private services, public services (ISTAT ACN, ISTAT CI)

high-duration (more than one-year) unemployment (as a fraction of the labour force) (ISTAT ASL) 


$\begin{array}{ll}Y^{*} & \text { OECD total imports in } 1970 \text { dollars (OECD) } \\ P_{M} & \text { implicit deflator of } M \\ P_{I M} & \text { implicit deflator of } I M \\ P_{X} & \text { implicit deflator of } X \\ P^{*} & \text { industrial countries export unit value (L) (IMFIFS, BI RA) } \\ J F R & \text { job-finding rate in industry excluding construction, computed as } \\ & \text { the number of newly hired employee out of existing operatives } \\ & (R S L) \\ J S R & \text { job separation rate in industry excluding construction, computed } \\ & \text { as the number of separations out of existing operatives }(R S L) \\ d_{j} & \text { dummy variable (=1 in year } j, 0 \text { elsewhere) }\end{array}$

Abbreviations for sources

$\begin{array}{ll}\text { ISTAT ACN } & \text { Istituto Centrale di Statistica, Annuario di Contabilità Nazionale } \\ \text { ISTAT CI } & \text { Istituto Centrale di Statistica, Collana di Informazioni } \\ \text { ISTAT BM } & \text { Istituto Centrale di Statistica, Bollettino Mensile } \\ \text { ISTAT ASL } & \text { Istituto Centrale di Statistica, Annuario di Statistiche del Lavoro } \\ B I R A & \text { Banca d'Italia, Relazione annuale } \\ I S C O & \text { Istituto di Studi sulla Congiuntura } \\ C E R & \text { Centro Europa Ricerche, Rapporto no. 4, 1984 } \\ P A & \text { P. Antonello, Investimenti in macchine e prodotto per ore lavorate } \\ & \text { nell'economia italiana, LUISS, Quaderni ISE, no. 12, 1984 } \\ R S & \text { G. Rosa and V. Siesto, Il capitale fisso industriale. Bologna: Il } \\ & \text { Mulino, 1985 } \\ R S L & \text { Rassegna di Statistiche del Lavoro }\end{array}$


THE NETHERLANDS

\begin{tabular}{|c|c|c|c|}
\hline & Unemployment rate ${ }^{a}$ & Log labour force ${ }^{a}$ & Log employment ${ }^{\mathrm{a}}$ \\
\hline 1960 & 0.012 & 6.627 & $6 \cdot 621$ \\
\hline 1961 & 0.009 & 6.631 & 6.628 \\
\hline 1962 & 0.008 & $6 \cdot 640$ & 6.636 \\
\hline 1963 & 0.008 & $6 \cdot 646$ & $6 \cdot 642$ \\
\hline 1964 & 0.007 & 6.653 & 6.650 \\
\hline 1965 & 0.008 & 6.657 & 6.653 \\
\hline 1966 & 0.010 & 6.661 & 6.656 \\
\hline 1967 & 0.019 & 6.664 & 6.655 \\
\hline 1968 & 0.017 & 6.667 & 6.659 \\
\hline 1969 & 0.015 & 6.675 & $6 \cdot 668$ \\
\hline 1970 & 0.014 & $6 \cdot 679$ & $6 \cdot 673$ \\
\hline 1971 & 0.019 & 6.683 & 6.675 \\
\hline 1972 & 0.030 & $6 \cdot 684$ & 6.671 \\
\hline 1973 & 0.031 & $6 \cdot 685$ & 6.672 \\
\hline 1974 & 0.037 & 6.689 & 6.672 \\
\hline 1975 & 0.053 & 6.693 & 6.669 \\
\hline 1976 & 0.056 & 6.694 & 6.669 \\
\hline 1977 & 0.055 & 6.695 & 6.670 \\
\hline 1978 & 0.055 & 6.698 & 6.673 \\
\hline 1979 & 0.056 & $6 \cdot 704$ & 6.679 \\
\hline 1980 & 0.063 & $6 \cdot 710$ & $6 \cdot 682$ \\
\hline 1981 & 0.092 & $6 \cdot 717$ & 6.675 \\
\hline 1982 & $0 \cdot 124$ & $6 \cdot 722$ & 6.665 \\
\hline 1983 & $0 \cdot 150$ & $6 \cdot 726$ & 6.656 \\
\hline 1984 & $0 \cdot 154$ & $6 \cdot 727$ & 6.655 \\
\hline
\end{tabular}

All notes appear to end of Netherlands data. 


\begin{tabular}{|c|c|c|}
\hline & $\begin{array}{l}\text { Growth in } \\
\text { real national income } \\
\end{array}$ & $\begin{array}{l}\text { Growth in } \\
\text { real production by firms }\end{array}$ \\
\hline 1960 & 0.075 & 0.099 \\
\hline 1961 & 0.039 & 0.035 \\
\hline 1962 & 0.040 & 0.044 \\
\hline 1963 & 0.046 & 0.043 \\
\hline 1964 & 0.088 & 0.099 \\
\hline 1965 & 0.059 & 0.059 \\
\hline 1966 & 0.022 & 0.028 \\
\hline 1967 & 0.058 & 0.060 \\
\hline 1968 & 0.071 & 0.070 \\
\hline 1969 & 0.062 & 0.067 \\
\hline 1970 & 0.051 & 0.062 \\
\hline 1971 & 0.035 & 0.039 \\
\hline 1972 & 0.048 & 0.041 \\
\hline 1973 & 0.052 & 0.049 \\
\hline 1974 & 0.006 & 0.042 \\
\hline 1975 & -0.011 & -0.006 \\
\hline 1976 & 0.057 & 0.054 \\
\hline 1977 & 0.024 & 0.022 \\
\hline 1978 & 0.021 & 0.025 \\
\hline 1979 & 0.009 & 0.025 \\
\hline 1980 & -0.007 & 0.007 \\
\hline 1981 & -0.013 & -0.011 \\
\hline 1982 & -0.008 & -0.021 \\
\hline 1983 & 0.010 & 0.007 \\
\hline 1984 & 0.035 & 0.025 \\
\hline
\end{tabular}

All notes appear to end of Netherlands data. 


\begin{tabular}{|c|c|c|c|}
\hline & Vacancy rate ${ }^{b}$ & $\begin{array}{c}\text { Capacity } \\
\text { utilization rate }^{c}\end{array}$ & $\begin{array}{l}\text { Growth in } \\
\text { real-wage cost }\end{array}$ \\
\hline 1960 & 0.022 & 0.917 & 0.043 \\
\hline 1961 & 0.028 & 0.902 & 0.056 \\
\hline 1962 & 0.028 & 0.886 & 0.034 \\
\hline 1963 & 0.027 & 0.871 & 0.054 \\
\hline 1964 & 0.029 & 0.906 & 0.086 \\
\hline 1965 & 0.028 & 0.903 & 0.061 \\
\hline 1966 & 0.025 & 0.873 & 0.058 \\
\hline 1967 & 0.015 & 0.855 & 0.056 \\
\hline 1968 & 0.017 & 0.861 & 0.052 \\
\hline 1969 & 0.027 & $0 \cdot 881$ & 0.076 \\
\hline 1970 & 0.027 & $0 \cdot 896$ & $0 \cdot 103$ \\
\hline 1971 & 0.023 & 0.865 & 0.032 \\
\hline 1972 & 0.013 & $0 \cdot 844$ & 0.044 \\
\hline 1973 & 0.014 & 0.880 & 0.074 \\
\hline 1974 & 0.014 & 0.989 & 0.077 \\
\hline 1975 & 0.010 & 0.850 & 0.033 \\
\hline 1976 & 0.010 & 0.913 & 0.023 \\
\hline 1977 & 0.011 & 0.916 & 0.022 \\
\hline 1978 & 0.013 & 0.925 & 0.021 \\
\hline 1979 & 0.013 & 0.938 & $0 \cdot 026$ \\
\hline 1980 & 0.011 & 0.926 & 0.000 \\
\hline 1981 & 0.004 & 0.908 & -0.018 \\
\hline 1982 & 0.002 & 0.864 & 0.003 \\
\hline 1983 & 0.002 & & 0.020 \\
\hline 1984 & 0.003 & & -0.056 \\
\hline
\end{tabular}

All notes appear at end of Netherlands data. 


\begin{tabular}{|c|c|c|c|}
\hline & Competitiveness $^{\mathrm{e}}$ & Wage inflation ${ }^{\mathrm{a}}$ & Price inflation ${ }^{a}$ \\
\hline 1960 & -0.026 & 0.082 & 0.039 \\
\hline 1961 & 0.012 & 0.072 & 0.016 \\
\hline 1962 & 0.000 & 0.059 & 0.025 \\
\hline 1963 & $0 \cdot 015$ & 0.090 & 0.036 \\
\hline 1964 & 0.000 & $0 \cdot 149$ & 0.063 \\
\hline 1965 & 0.008 & $0 \cdot 111$ & 0.050 \\
\hline 1966 & -0.018 & $0 \cdot 110$ & 0.052 \\
\hline 1967 & -0.008 & 0.088 & 0.032 \\
\hline 1968 & 0.002 & 0.089 & 0.037 \\
\hline 1969 & $-0 \cdot 016$ & $0 \cdot 134$ & $0 \cdot 058$ \\
\hline 1970 & -0.006 & $0 \cdot 130$ & 0.027 \\
\hline 1971 & -0.002 & $0 \cdot 137$ & $0 \cdot 105$ \\
\hline 1972 & $-0 \cdot 002$ & $0 \cdot 123$ & 0.079 \\
\hline 1973 & -0.059 & $0 \cdot 158$ & 0.084 \\
\hline 1974 & -0.004 & $0 \cdot 157$ & 0.080 \\
\hline 1975 & 0.038 & $0 \cdot 126$ & 0.093 \\
\hline 1976 & 0.010 & $0 \cdot 109$ & 0.086 \\
\hline 1977 & 0.036 & 0.087 & 0.065 \\
\hline 1978 & -0.031 & 0.072 & 0.051 \\
\hline 1979 & $-0 \cdot 030$ & $0 \cdot 062$ & $0 \cdot 036$ \\
\hline 1980 & $-0 \cdot 027$ & 0.059 & 0.059 \\
\hline 1981 & -0.019 & 0.043 & 0.061 \\
\hline 1982 & 0.033 & 0.061 & 0.064 \\
\hline 1983 & 0 & $0 \cdot 040$ & 0.020 \\
\hline 1984 & -0.010 & 0.005 & 0.061 \\
\hline
\end{tabular}

All notes appear to end of Netherlands data. 


\begin{tabular}{lcc}
\hline & $\begin{array}{c}\text { Unionists relative } \\
\text { to employees }^{\mathrm{f}}\end{array}$ & $\begin{array}{c}\text { Workers involved in } \\
\text { industrial conflicts }\end{array}$ \\
\hline 1960 & & $0 \cdot 028$ \\
1961 & & $0 \cdot 003$ \\
1962 & & $0 \cdot 001$ \\
1963 & & $0 \cdot 009$ \\
1964 & & $0 \cdot 003$ \\
1965 & & $0 \cdot 007$ \\
1966 & $0 \cdot 32$ & $0 \cdot 004$ \\
1967 & $0 \cdot 32$ & $0 \cdot 005$ \\
1968 & $0 \cdot 31$ & $0 \cdot 001$ \\
1969 & $0 \cdot 31$ & $0 \cdot 004$ \\
1970 & $0 \cdot 36$ & $0 \cdot 016$ \\
1971 & $0 \cdot 37$ & $0 \cdot 011$ \\
1972 & $0 \cdot 38$ & $0 \cdot 006$ \\
1973 & $0 \cdot 38$ & $0 \cdot 017$ \\
1974 & $0 \cdot 40$ & $0 \cdot 001$ \\
1975 & $0 \cdot 40$ & $0 \cdot 000$ \\
1976 & $0 \cdot 40$ & $0 \cdot 005$ \\
1977 & $0 \cdot 41$ & $0 \cdot 013$ \\
1978 & $0 \cdot 40$ & $0 \cdot 003$ \\
1979 & $0 \cdot 40$ & $0 \cdot 011$ \\
1980 & $0 \cdot 39$ & $0 \cdot 007$ \\
1981 & $0 \cdot 38$ & $0 \cdot 003$ \\
1982 & $0 \cdot 37$ & $0 \cdot 022$ \\
1983 & $0 \cdot 32$ & $0 \cdot 003$ \\
1984 & & \\
\hline
\end{tabular}

All notes appear at end of Netherlands data. 


\begin{tabular}{cccc}
\hline & $\begin{array}{c}\text { Employers' employment } \\
\text { tax rate }\end{array}$ & $\begin{array}{c}\text { Workers' } \\
\text { tax rate }\end{array}$ & $\begin{array}{c}\text { Indirect } \\
\text { tax rate }^{\mathrm{m}}\end{array}$ \\
\hline 1960 & $0 \cdot 135$ & $0 \cdot 220$ & $0 \cdot 109$ \\
1961 & $0 \cdot 127$ & $0 \cdot 230$ & $0 \cdot 111$ \\
1962 & $0 \cdot 134$ & $0 \cdot 229$ & $0 \cdot 110$ \\
1963 & $0 \cdot 148$ & $0 \cdot 240$ & $0 \cdot 111$ \\
1964 & $0 \cdot 152$ & $0 \cdot 248$ & $0 \cdot 110$ \\
1965 & $0 \cdot 151$ & $0 \cdot 257$ & $0 \cdot 111$ \\
1966 & $0 \cdot 166$ & $0 \cdot 276$ & $0 \cdot 115$ \\
1967 & $0 \cdot 175$ & $0 \cdot 288$ & $0 \cdot 104$ \\
1968 & $0 \cdot 188$ & $0 \cdot 298$ & $0 \cdot 105$ \\
1969 & $0 \cdot 192$ & $0 \cdot 306$ & $0 \cdot 101$ \\
1970 & $0 \cdot 193$ & $0 \cdot 311$ & $0 \cdot 117$ \\
1971 & $0 \cdot 199$ & $0 \cdot 326$ & $0 \cdot 120$ \\
1972 & $0 \cdot 202$ & $0 \cdot 333$ & $0 \cdot 124$ \\
1973 & $0 \cdot 216$ & $0 \cdot 346$ & $0 \cdot 122$ \\
1974 & $0 \cdot 221$ & $0 \cdot 360$ & $0 \cdot 116$ \\
1975 & $0 \cdot 222$ & $0 \cdot 363$ & $0 \cdot 119$ \\
1976 & $0 \cdot 225$ & $0 \cdot 357$ & $0 \cdot 121$ \\
1977 & $0 \cdot 220$ & $0 \cdot 343$ & $0 \cdot 129$ \\
1978 & $0 \cdot 219$ & $0 \cdot 344$ & $0 \cdot 133$ \\
1979 & $0 \cdot 223$ & $0 \cdot 350$ & $0 \cdot 132$ \\
1980 & $0 \cdot 225$ & $0 \cdot 354$ & $0 \cdot 133$ \\
1981 & $0 \cdot 225$ & $0 \cdot 348$ & $0 \cdot 130$ \\
1982 & $0 \cdot 220$ & $0 \cdot 346$ & $0 \cdot 128$ \\
1983 & $0 \cdot 231$ & $0 \cdot 363$ & $0 \cdot 132$ \\
1984 & & & \\
\hline & & & \\
\hline
\end{tabular}

All notes appear to end of Netherlands data. 


\begin{tabular}{|c|c|}
\hline & User cost of capital ${ }^{c}$ \\
\hline 1960 & 0.031 \\
\hline 1961 & 0.027 \\
\hline 1962 & 0.003 \\
\hline 1963 & 0.028 \\
\hline 1964 & 0.082 \\
\hline 1965 & $0 \cdot 061$ \\
\hline 1966 & 0.090 \\
\hline 1967 & 0.008 \\
\hline 1968 & $0 \cdot 018$ \\
\hline 1969 & $0 \cdot 125$ \\
\hline 1970 & $0 \cdot 132$ \\
\hline 1971 & 0.093 \\
\hline 1972 & 0.028 \\
\hline 1973 & 0.009 \\
\hline 1974 & $0 \cdot 119$ \\
\hline 1975 & $0 \cdot 113$ \\
\hline 1976 & 0.053 \\
\hline 1977 & -0.009 \\
\hline 1978 & -0.058 \\
\hline 1979 & 0.044 \\
\hline 1980 & $0 \cdot 142$ \\
\hline 1981 & $0 \cdot 141$ \\
\hline 1982 & 0.060 \\
\hline 1983 & \\
\hline 1984 & \\
\hline
\end{tabular}

Notes

${ }^{a}$ Source: Central Planning Bureau, Central Economic Plans 1978, 1979 and 1985; new definition from 1969 onwards

${ }^{\mathrm{b}}$ Source: Central Bureau of Statistics, Maandschrift

${ }^{\mathrm{c}}$ Own computation

${ }^{\mathrm{d}}$ Source: see note (a); wage inflation minus price inflation

e Source: see note (a); $\Delta \ln$ export price minus $\Delta \ln$ foreign competitors' price (guilders; double reweighted from 1970 onwards); energy excluded after 1972; a negative change indicates an improvement of competitiveness

${ }^{\mathrm{f}}$ Source: see note (b); until 1969, only members of the three most important unions

${ }^{\mathrm{g}}$ Source: ILO, Yearbook of Labour Statistics, and Central Planning Bureau, Central Economic Plan; relative to employees in employment

${ }^{\mathrm{h}}$ Source: Central Bureau of Statistics, National Accounts; social security contributions relative to wages plus salaries plus social security contributions

${ }^{\mathrm{k}}$ Source: see note (h); household direct taxes plus household social security premiums relative to total household income minus non-household social security contributions

${ }^{\mathrm{m}}$ Source: see notes (a) and (h). 
JAPAN

\begin{tabular}{|c|c|c|c|c|c|c|}
\hline & $\begin{array}{c}\text { Unemployment } \\
\text { rate } \\
(\%)\end{array}$ & $\begin{array}{l}\text { Log labour } \\
\text { force } \\
(10,000 \\
\text { persons })\end{array}$ & $\begin{array}{c}\text { Log } \\
\text { employment } \\
(10,000 \\
\text { persons })\end{array}$ & $\begin{array}{l}\text { Log real } \\
\text { GDP } \\
\text { (billion } \\
\text { yen) }\end{array}$ & $\begin{array}{l}\text { JOJW } \\
\text { ratio } \\
\text { (ratio) }\end{array}$ & $\begin{array}{c}\text { Capacity } \\
\text { utilization } \\
\text { (index) }\end{array}$ \\
\hline $\begin{array}{l}1953 \\
1954\end{array}$ & $\begin{array}{l}1 \cdot 85 \\
2 \cdot 25\end{array}$ & $\begin{array}{l}8 \cdot 29 \\
8 \cdot 30\end{array}$ & $\begin{array}{l}7 \cdot 41 \\
7 \cdot 44\end{array}$ & & & \\
\hline $\begin{array}{l}1955 \\
1956 \\
1957 \\
1958 \\
1959\end{array}$ & $\begin{array}{l}2 \cdot 38 \\
2 \cdot 29 \\
1 \cdot 96 \\
2 \cdot 04 \\
2 \cdot 23\end{array}$ & $\begin{array}{l}8 \cdot 34 \\
8 \cdot 35 \\
8 \cdot 38 \\
8 \cdot 38 \\
8 \cdot 39\end{array}$ & $\begin{array}{l}7 \cdot 48 \\
7 \cdot 55 \\
7 \cdot 62 \\
7 \cdot 66 \\
7 \cdot 71\end{array}$ & & & $(101 \cdot 6)$ \\
\hline $\begin{array}{l}1960 \\
1961 \\
1962 \\
1963 \\
1964\end{array}$ & $\begin{array}{l}1 \cdot 62 \\
1 \cdot 30 \\
1 \cdot 28 \\
1 \cdot 16 \\
1 \cdot 18\end{array}$ & $\begin{array}{l}8 \cdot 41 \\
8 \cdot 42 \\
8 \cdot 41 \\
8 \cdot 44 \\
8 \cdot 45\end{array}$ & $\begin{array}{l}7 \cdot 77 \\
7 \cdot 81 \\
7 \cdot 86 \\
7 \cdot 89 \\
7 \cdot 92\end{array}$ & & $\begin{array}{l}0 \cdot 68 \\
0 \cdot 70 \\
0.79\end{array}$ & $\begin{array}{l}(106 \cdot 4) \\
(107 \cdot 6) \\
(100 \cdot 8) \\
(101 \cdot 3) \\
(106 \cdot 1)\end{array}$ \\
\hline $\begin{array}{l}1965 \\
1966 \\
1967 \\
1968 \\
1969\end{array}$ & $\begin{array}{l}1 \cdot 22 \\
1 \cdot 31 \\
1 \cdot 26 \\
1 \cdot 18 \\
1 \cdot 12\end{array}$ & $\begin{array}{l}8 \cdot 47 \\
8 \cdot 49 \\
8 \cdot 51 \\
8 \cdot 52 \\
8 \cdot 53\end{array}$ & $\begin{array}{l}7 \cdot 96 \\
8 \cdot 00 \\
8 \cdot 02 \\
8 \cdot 05 \\
8 \cdot 07\end{array}$ & $\begin{array}{l}11 \cdot 14 \\
11 \cdot 24 \\
11 \cdot 34 \\
11 \cdot 46 \\
11 \cdot 58\end{array}$ & $\begin{array}{l}0.64 \\
0 \cdot 73 \\
1 \cdot 00 \\
1 \cdot 12 \\
1 \cdot 30\end{array}$ & $\begin{array}{c}(100 \cdot 0) \\
(106 \cdot 5) \\
(115 \cdot 7) \\
112 \cdot 2(117 \cdot 5) \\
112 \cdot 8\end{array}$ \\
\hline $\begin{array}{l}1970 \\
1971 \\
1972 \\
1973 \\
1974\end{array}$ & $\begin{array}{l}1 \cdot 15 \\
1 \cdot 23 \\
1 \cdot 39 \\
1 \cdot 27 \\
1 \cdot 38\end{array}$ & $\begin{array}{l}8 \cdot 54 \\
8 \cdot 55 \\
8 \cdot 55 \\
8 \cdot 58 \\
8 \cdot 57\end{array}$ & $\begin{array}{l}8 \cdot 10 \\
8 \cdot 13 \\
8 \cdot 15 \\
8 \cdot 19 \\
8 \cdot 19\end{array}$ & $\begin{array}{l}11 \cdot 67 \\
11 \cdot 72 \\
11 \cdot 80 \\
11 \cdot 89 \\
11 \cdot 88\end{array}$ & $\begin{array}{l}1 \cdot 41 \\
1 \cdot 12 \\
1 \cdot 16 \\
1 \cdot 76 \\
1 \cdot 20\end{array}$ & $\begin{array}{r}110 \cdot 0 \\
103 \cdot 7 \\
104 \cdot 4 \\
108 \cdot 4 \\
99 \cdot 2\end{array}$ \\
\hline $\begin{array}{l}1975 \\
1976 \\
1977 \\
1978 \\
1979\end{array}$ & $\begin{array}{l}1 \cdot 89 \\
2 \cdot 01 \\
2 \cdot 03 \\
2 \cdot 24 \\
2 \cdot 08\end{array}$ & $\begin{array}{l}8 \cdot 57 \\
8 \cdot 59 \\
8 \cdot 60 \\
8 \cdot 61 \\
8 \cdot 62\end{array}$ & $\begin{array}{l}8 \cdot 20 \\
8 \cdot 21 \\
8 \cdot 23 \\
8 \cdot 24 \\
8 \cdot 26\end{array}$ & $\begin{array}{l}11 \cdot 90 \\
11 \cdot 95 \\
12 \cdot 00 \\
12 \cdot 05 \\
12 \cdot 10\end{array}$ & $\begin{array}{l}0 \cdot 61 \\
0 \cdot 64 \\
0 \cdot 56 \\
0 \cdot 71 \\
0 \cdot 75\end{array}$ & $\begin{array}{l}84 \cdot 6 \\
91 \cdot 6 \\
90 \cdot 9 \\
94 \cdot 3 \\
99 \cdot 9\end{array}$ \\
\hline $\begin{array}{l}1980 \\
1981 \\
1982 \\
1983 \\
1984\end{array}$ & $\begin{array}{l}2 \cdot 01 \\
2 \cdot 21 \\
2 \cdot 36 \\
2 \cdot 64 \\
2 \cdot 71\end{array}$ & $\begin{array}{l}8 \cdot 63 \\
8 \cdot 64 \\
8 \cdot 66 \\
8 \cdot 68 \\
8 \cdot 68\end{array}$ & $\begin{array}{l}8 \cdot 28 \\
8 \cdot 30 \\
8 \cdot 31 \\
8 \cdot 34 \\
8 \cdot 35\end{array}$ & $\begin{array}{l}12 \cdot 15 \\
12 \cdot 19 \\
12 \cdot 22 \\
12 \cdot 25\end{array}$ & $\begin{array}{l}0.75 \\
0 \cdot 68 \\
0 \cdot 61 \\
0 \cdot 60 \\
0.65\end{array}$ & $\begin{array}{r}100 \cdot 0 \\
95 \cdot 4 \\
92 \cdot 6 \\
94 \cdot 1 \\
102 \cdot 0\end{array}$ \\
\hline
\end{tabular}




\begin{tabular}{|c|c|c|c|c|c|c|}
\hline & $\begin{array}{l}\text { Log labour } \\
\text { cost per } \\
\text { hour } \\
\text { relative to } \\
\text { producer } \\
\text { prices } \\
\text { (yen per } \\
\text { man-hour) }\end{array}$ & $\begin{array}{c}\text { Log capital- } \\
\text { employment } \\
\text { ratio } \\
\text { (yen } \\
\text { per man) }\end{array}$ & $\begin{array}{l}\text { Log } \\
\text { competi- } \\
\text { tiveness } \\
\text { (ratio) }\end{array}$ & $\begin{array}{c}\text { Wage } \\
\text { inflation } \\
\text { (log hourly } \\
\text { wages) } \\
\text { (yen } \\
\text { per hour) }\end{array}$ & $\begin{array}{c}\text { Price } \\
\text { inflation } \\
\text { (log GDP } \\
\text { deflator) } \\
\text { (index) }\end{array}$ & $\begin{array}{c}\text { Unionists } \\
\text { as \% of } \\
\text { employees } \\
\text { (\%) }\end{array}$ \\
\hline $\begin{array}{l}1953 \\
1954\end{array}$ & $\begin{array}{l}(2 \cdot 75) \\
(2 \cdot 78)\end{array}$ & & $\begin{array}{l}(0 \cdot 29) \\
(0 \cdot 29)\end{array}$ & $\begin{array}{l}4 \cdot 28 \\
4 \cdot 43\end{array}$ & & $\begin{array}{l}36 \cdot 3 \\
35 \cdot 5\end{array}$ \\
\hline $\begin{array}{l}1955 \\
1956 \\
1957 \\
1958 \\
1959\end{array}$ & $\begin{array}{l}(2 \cdot 80) \\
(2 \cdot 79) \\
(2 \cdot 79) \\
(2 \cdot 86) \\
(2 \cdot 87)\end{array}$ & & $\begin{array}{l}(0 \cdot 29) \\
(0 \cdot 33) \\
(0 \cdot 30) \\
(0 \cdot 33) \\
(0 \cdot 40)\end{array}$ & $\begin{array}{l}4 \cdot 49 \\
4 \cdot 52 \\
4 \cdot 61 \\
4 \cdot 67 \\
4 \cdot 66\end{array}$ & & $\begin{array}{l}35 \cdot 6 \\
33 \cdot 5 \\
33 \cdot 6 \\
32 \cdot 7 \\
32 \cdot 1\end{array}$ \\
\hline $\begin{array}{l}1960 \\
1961 \\
1962 \\
1963 \\
1964\end{array}$ & $\begin{array}{l}(2 \cdot 90) \\
(2 \cdot 96) \\
(3 \cdot 07) \\
(3 \cdot 16) \\
(3 \cdot 24)\end{array}$ & & $\begin{array}{c}0.83(0.42) \\
0.95 \\
0.79 \\
0.78 \\
0.79\end{array}$ & $\begin{array}{l}4 \cdot 78 \\
4 \cdot 88 \\
5 \cdot 00 \\
5 \cdot 11 \\
5 \cdot 23\end{array}$ & & $\begin{array}{l}32 \cdot 2 \\
34 \cdot 5 \\
34 \cdot 7 \\
34 \cdot 7 \\
35 \cdot 0\end{array}$ \\
\hline $\begin{array}{l}1965 \\
1966 \\
1967 \\
1968 \\
1969\end{array}$ & $\begin{array}{c}3 \cdot 81(3 \cdot 31) \\
3 \cdot 85 \\
3 \cdot 91 \\
4 \cdot 00 \\
4 \cdot 16\end{array}$ & $\begin{array}{l}14 \cdot 74 \\
14 \cdot 81 \\
14 \cdot 91 \\
15 \cdot 02\end{array}$ & $\begin{array}{l}0 \cdot 80 \\
0 \cdot 78 \\
0 \cdot 79 \\
0 \cdot 79 \\
0 \cdot 79\end{array}$ & $\begin{array}{l}5 \cdot 31 \\
5 \cdot 42 \\
5 \cdot 53 \\
5 \cdot 66 \\
5 \cdot 82\end{array}$ & $\begin{array}{l}3 \cdot 85 \\
3 \cdot 90 \\
3 \cdot 96 \\
4 \cdot 01 \\
4 \cdot 05\end{array}$ & $\begin{array}{l}34 \cdot 8 \\
34 \cdot 2 \\
34 \cdot 1 \\
34 \cdot 4 \\
35 \cdot 2\end{array}$ \\
\hline $\begin{array}{l}1970 \\
1971 \\
1972 \\
1973 \\
1974\end{array}$ & $\begin{array}{l}4 \cdot 20 \\
4 \cdot 31 \\
4 \cdot 40 \\
4 \cdot 48 \\
4 \cdot 56\end{array}$ & $\begin{array}{l}15 \cdot 12 \\
15 \cdot 21 \\
15 \cdot 31 \\
15 \cdot 37 \\
15 \cdot 45\end{array}$ & $\begin{array}{l}0 \cdot 80 \\
0 \cdot 79 \\
0 \cdot 80 \\
0 \cdot 71 \\
0 \cdot 48\end{array}$ & $\begin{array}{l}6 \cdot 00 \\
6 \cdot 15 \\
6 \cdot 30 \\
6 \cdot 51 \\
6 \cdot 78\end{array}$ & $\begin{array}{l}4 \cdot 13 \\
4 \cdot 18 \\
4 \cdot 23 \\
4 \cdot 34 \\
4 \cdot 53\end{array}$ & $\begin{array}{l}35 \cdot 4 \\
34 \cdot 8 \\
34 \cdot 3 \\
33 \cdot 1 \\
33 \cdot 9\end{array}$ \\
\hline $\begin{array}{l}1975 \\
1976 \\
1977 \\
1978 \\
1979\end{array}$ & $\begin{array}{l}4 \cdot 66 \\
4 \cdot 69 \\
4 \cdot 73 \\
4 \cdot 75 \\
4 \cdot 77\end{array}$ & $\begin{array}{l}15 \cdot 52 \\
15 \cdot 57 \\
15 \cdot 62 \\
15 \cdot 67 \\
15 \cdot 71\end{array}$ & $\begin{array}{l}0 \cdot 37 \\
0 \cdot 31 \\
0 \cdot 31 \\
0 \cdot 43 \\
0 \cdot 28\end{array}$ & $\begin{array}{l}6 \cdot 93 \\
7 \cdot 05 \\
7 \cdot 13 \\
7 \cdot 20 \\
7 \cdot 24\end{array}$ & $\begin{array}{l}4 \cdot 60 \\
4 \cdot 61 \\
4 \cdot 72 \\
4 \cdot 76 \\
4 \cdot 79\end{array}$ & $\begin{array}{l}34 \cdot 4 \\
33 \cdot 7 \\
33 \cdot 2 \\
32 \cdot 6 \\
31 \cdot 6\end{array}$ \\
\hline $\begin{array}{l}1980 \\
1981 \\
1982 \\
1983 \\
1984\end{array}$ & $\begin{array}{l}4 \cdot 81 \\
4 \cdot 85 \\
4 \cdot 87 \\
4 \cdot 89\end{array}$ & $\begin{array}{l}15 \cdot 75 \\
15 \cdot 80 \\
15 \cdot 84 \\
15 \cdot 87\end{array}$ & $\begin{array}{c}0.00 \\
-0.004 \\
-0.04 \\
-0.02 \\
0.01\end{array}$ & $\begin{array}{l}7 \cdot 31 \\
7 \cdot 37 \\
7 \cdot 41 \\
7 \cdot 43 \\
7 \cdot 50\end{array}$ & $\begin{array}{l}4 \cdot 82 \\
4 \cdot 84 \\
4 \cdot 86 \\
4 \cdot 87\end{array}$ & $\begin{array}{l}30 \cdot 8 \\
30 \cdot 8 \\
30 \cdot 5 \\
29 \cdot 7 \\
29 \cdot 1\end{array}$ \\
\hline
\end{tabular}




\begin{tabular}{|c|c|c|c|c|c|c|}
\hline & $\begin{array}{l}\text { Industrial } \\
\text { conflicts }^{\mathrm{a}} \\
\text { (hours per } \\
\text { man) }\end{array}$ & $\begin{array}{c}\text { Employers' } \\
\text { employment } \\
\text { tax } \text { rate }^{\mathrm{b}} \\
(\%)\end{array}$ & $\begin{array}{c}\begin{array}{c}\text { Workers' } \\
\text { tax rates }^{\mathrm{b}}\end{array} \\
(\%)\end{array}$ & $\begin{array}{c}\text { Indirect } \\
\text { tax rate } \\
(\%)\end{array}$ & $\begin{array}{c}\begin{array}{c}\text { Duration of } \\
\text { unemployment }\end{array} \\
(\%)\end{array}$ & $\begin{array}{l}\text { Log employed } \\
\text { (including } \\
\text { self- } \\
\text { employment) } \\
(10,000 \\
\text { persons) }\end{array}$ \\
\hline $\begin{array}{l}1953 \\
1954\end{array}$ & $\begin{array}{l}0 \cdot 25 \\
0 \cdot 22\end{array}$ & $\begin{array}{l}(1 \cdot 62) \\
(1 \cdot 70)\end{array}$ & $\begin{array}{l}(8 \cdot 27) \\
(8 \cdot 13)\end{array}$ & $\begin{array}{l}(14 \cdot 7) \\
(13 \cdot 8)\end{array}$ & & $\begin{array}{l}8 \cdot 27 \\
8 \cdot 28\end{array}$ \\
\hline $\begin{array}{l}1955 \\
1956 \\
1957 \\
1958 \\
1959\end{array}$ & $\begin{array}{l}0 \cdot 19 \\
0 \cdot 23 \\
0 \cdot 27 \\
0 \cdot 28 \\
0 \cdot 26\end{array}$ & $\begin{array}{l}(1.82) \\
(1.91) \\
(1.91) \\
(1.95) \\
(1.99)\end{array}$ & $\begin{array}{l}(7 \cdot 82) \\
(7 \cdot 80) \\
(7 \cdot 17) \\
(7 \cdot 05) \\
(6 \cdot 66)\end{array}$ & $\begin{array}{l}(14 \cdot 0) \\
(13 \cdot 9) \\
(14 \cdot 5) \\
(14 \cdot 2) \\
(15 \cdot 0)\end{array}$ & & $\begin{array}{l}8 \cdot 31 \\
8 \cdot 33 \\
8 \cdot 36 \\
8 \cdot 36 \\
8 \cdot 37\end{array}$ \\
\hline $\begin{array}{l}1960 \\
1961 \\
1962 \\
1963 \\
1964\end{array}$ & $\begin{array}{l}0 \cdot 20 \\
0 \cdot 24 \\
0 \cdot 20 \\
0 \cdot 10 \\
0 \cdot 11\end{array}$ & $\begin{array}{l}(2 \cdot 01) \\
(2 \cdot 08) \\
(2 \cdot 16) \\
(2 \cdot 45) \\
(2 \cdot 54)\end{array}$ & $\begin{array}{l}(7 \cdot 12) \\
(7 \cdot 70) \\
(8 \cdot 31) \\
(8 \cdot 73) \\
(9 \cdot 07)\end{array}$ & $\begin{array}{l}(15 \cdot 4) \\
(16 \cdot 3) \\
(15 \cdot 1) \\
(14 \cdot 4) \\
(13 \cdot 9)\end{array}$ & & $\begin{array}{l}8 \cdot 39 \\
8 \cdot 41 \\
8 \cdot 42 \\
8 \cdot 43 \\
8 \cdot 44\end{array}$ \\
\hline $\begin{array}{l}1965 \\
1966 \\
1967 \\
1968 \\
1969\end{array}$ & $\begin{array}{l}0 \cdot 19 \\
0 \cdot 09 \\
0 \cdot 05 \\
0 \cdot 09 \\
0 \cdot 11\end{array}$ & $\begin{array}{c}2 \cdot 73(2 \cdot 82) \\
2 \cdot 84 \\
2 \cdot 86 \\
2 \cdot 87 \\
2 \cdot 87\end{array}$ & $\begin{array}{c}9 \cdot 24(9 \cdot 47) \\
9 \cdot 37 \\
9 \cdot 53 \\
9 \cdot 80 \\
9 \cdot 98\end{array}$ & $\begin{array}{c}12 \cdot 5(13 \cdot 4) \\
12 \cdot 3 \\
12 \cdot 5 \\
13 \cdot 0 \\
12 \cdot 7\end{array}$ & & $\begin{array}{l}8 \cdot 46 \\
8 \cdot 48 \\
8 \cdot 50 \\
8 \cdot 51 \\
8 \cdot 52\end{array}$ \\
\hline $\begin{array}{l}1970 \\
1971 \\
1972 \\
1973 \\
1974\end{array}$ & $\begin{array}{l}0 \cdot 11 \\
0 \cdot 17 \\
0 \cdot 14 \\
0 \cdot 12 \\
0 \cdot 26\end{array}$ & $\begin{array}{l}2 \cdot 96 \\
3 \cdot 23 \\
3 \cdot 34 \\
3 \cdot 25 \\
3 \cdot 67\end{array}$ & $\begin{array}{l}10 \cdot 5 \\
11 \cdot 2 \\
11 \cdot 3 \\
11 \cdot 5 \\
11 \cdot 8\end{array}$ & $\begin{array}{l}13 \cdot 5 \\
13 \cdot 2 \\
13 \cdot 0 \\
13 \cdot 0 \\
12 \cdot 7\end{array}$ & $\begin{array}{l}24 \cdot 5 \\
19 \cdot 1 \\
15 \cdot 7\end{array}$ & $\begin{array}{l}8 \cdot 53 \\
8 \cdot 54 \\
8 \cdot 54 \\
8 \cdot 56 \\
8 \cdot 56\end{array}$ \\
\hline $\begin{array}{l}1975 \\
1976 \\
1977 \\
1978 \\
1979\end{array}$ & $\begin{array}{l}0 \cdot 21 \\
0 \cdot 08 \\
0 \cdot 04 \\
0 \cdot 03 \\
0 \cdot 02\end{array}$ & $\begin{array}{l}4 \cdot 43 \\
4 \cdot 37 \\
4 \cdot 72 \\
4 \cdot 79 \\
4 \cdot 84\end{array}$ & $\begin{array}{l}12 \cdot 2 \\
12 \cdot 2 \\
12 \cdot 8 \\
12 \cdot 7 \\
14 \cdot 0\end{array}$ & $\begin{array}{l}11 \cdot 5 \\
11 \cdot 4 \\
12 \cdot 1 \\
12 \cdot 0 \\
12 \cdot 7\end{array}$ & $\begin{array}{l}27 \cdot 5 \\
31 \cdot 2 \\
37 \cdot 7\end{array}$ & $\begin{array}{l}8 \cdot 56 \\
8 \cdot 56 \\
8 \cdot 58 \\
8 \cdot 59 \\
8 \cdot 60\end{array}$ \\
\hline $\begin{array}{l}1980 \\
1981 \\
1982 \\
1983 \\
1984\end{array}$ & $\begin{array}{l}0 \cdot 02 \\
0 \cdot 01 \\
0 \cdot 01 \\
0 \cdot 01 \\
0 \cdot 00\end{array}$ & $\begin{array}{l}5 \cdot 12 \\
5 \cdot 57 \\
5 \cdot 77 \\
5 \cdot 77\end{array}$ & $\begin{array}{l}14 \cdot 3 \\
15 \cdot 2 \\
15 \cdot 5 \\
15 \cdot 8\end{array}$ & $\begin{array}{l}12 \cdot 8 \\
13 \cdot 1 \\
13 \cdot 1 \\
12 \cdot 7\end{array}$ & $\begin{array}{l}35 \cdot 4 \\
30 \cdot 2 \\
31 \cdot 2 \\
32 \cdot 3 \\
35 \cdot 6\end{array}$ & $\begin{array}{l}8 \cdot 61 \\
8 \cdot 62 \\
8 \cdot 63 \\
8 \cdot 65 \\
8 \cdot 65\end{array}$ \\
\hline
\end{tabular}

Notes:

${ }^{a}$ Workers involved in industrial conflicts as percentage of employees in employment

${ }^{\mathrm{b}}$ Includes social security contributions 
Data sources and calculation methods

(1) Unemployment rate: Management and Coordination Agency, Survey of Labour Force.

(2) Labour force: as in (1).

(3) Employment (excluding self-employed): as in (1).

(4) Real GDP: Economic Planning Agency, Annual Bulletin of National Income Statistics, 1975 constant prices.

(5) Job-offered-job-wanted ratio: Ministry of Labour, Bulletin of Occupational Stability. Vacancy rate cannot be singled out because of data inconsistency between unemployment rate and JOJW ratio.

(6) Capacity utilization: Ministry of International Trade and Industry, International Trade and Industry Statistics, 1968-84; average $=100$ (1984). Figures in parentheses are based on average $=100$ (1965).

(7) Labour cost per hour relative to producer price: Economic Planning Agency, Annual Bulletin of National Income Statistics; Ministry of Labour, Monthly Bulletin of Labour Statistics; Management and Coordination Agency, Survey of Labour Force. Employees' income: average monthly hours worked per regular worker (whole industry including service industry since 1970$) \times 12 \times$ GNP deflator $\times$ total number of employees. Figures in parentheses are based on old SNA data.

(8) Capital-employment ratio: Economic Planning Agency, Capital Stock Statistics of Private Firms; Management and Coordination Agency, Survey of Labour Force. Capital stock is on installment basis.

(9) Competitiveness: Bank of Japan, Annual Bulletin of Wholesale Price Index, export prices divided by import prices. Figures in parentheses are based on average $=100$ (1975); others on average $=100$ (1980).

(10) Wage inflation: Ministry of Labour, Monthly Bulletin of Labour Statistics; total cash earnings of regular workers, average monthly hours worked per regular worker.

(11) Price inflation: as in (4).

(12) Unionists as percentage of employees; Ministry of Labour, Basic Survey of Trade Unions; Management and Coordination Agency, Survey of Labour Force.

(13) Workers involved in industrial conflicts as percentage of employees: Employment Ministry of Labour, Survey of Industrial Dispute Statistics; Management and Coordination Agency, Survey of Labour Force.

(14) Employers' employment tax rate (including social security contributions): as in (4). Employers' social security contributions: employees' income + firms' income. Figures in parentheses are based on old SNA data.

(15) Workers' tax rate (including social security contributions): as in (4). Household's sector data: Direct taxes + social security contributions; total receipts.

(16) Indirect tax rate: as in (4); indirect taxes; private final consumption expenditure.

(17) Duration of unemployment: the percentage of unemployed who have been unemployed for over six months; Ministry of Labour, Special Survey of Labour Force. Survey data are based on figures in March 1972, 1974, 1977, 1978, 1979, 1980, 1981, 1982; February 1983, 1984; and October 1971, not on yearly average figures.

(18) Numbers employed (including self-employed): as in (1). 


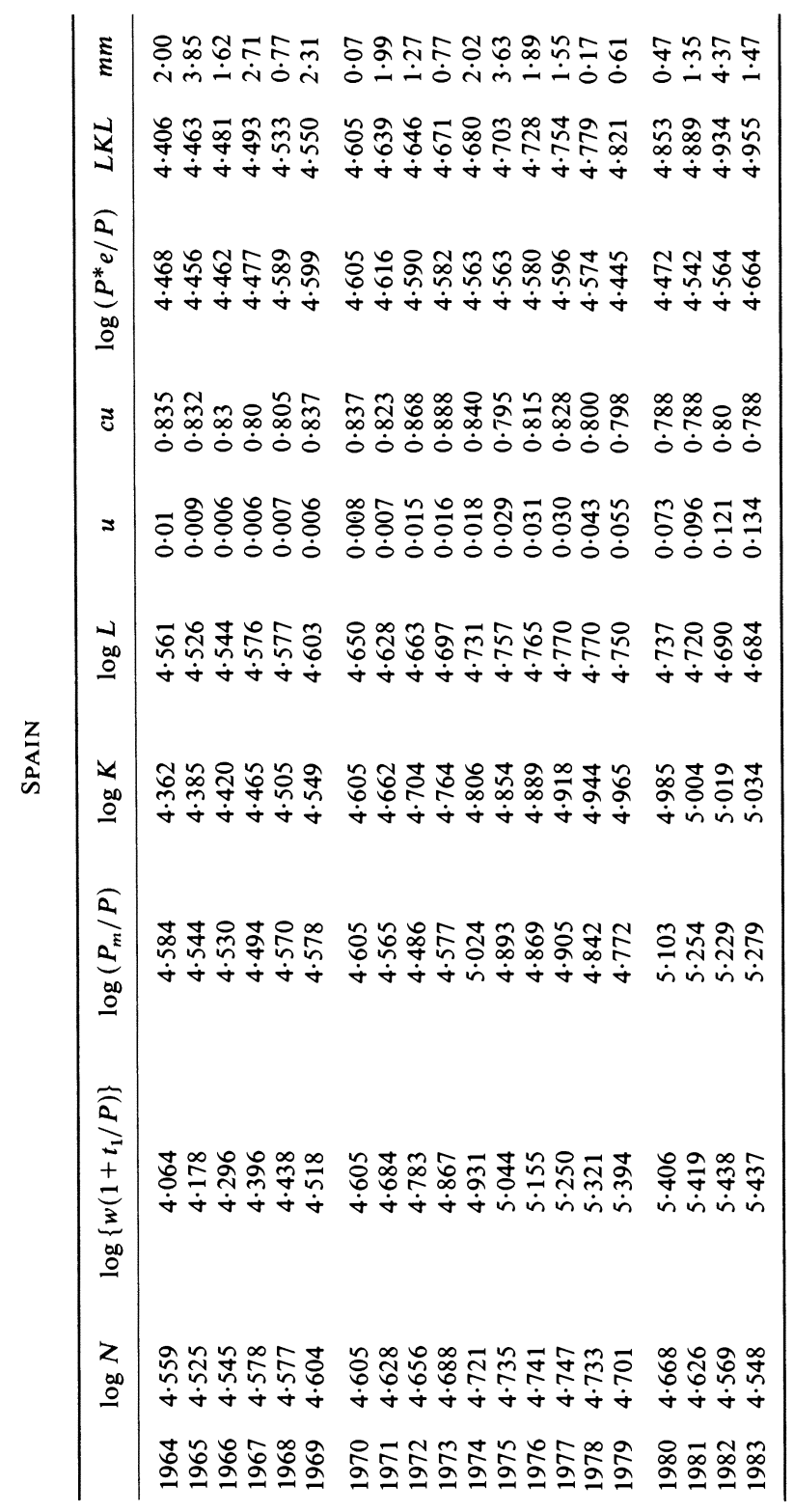




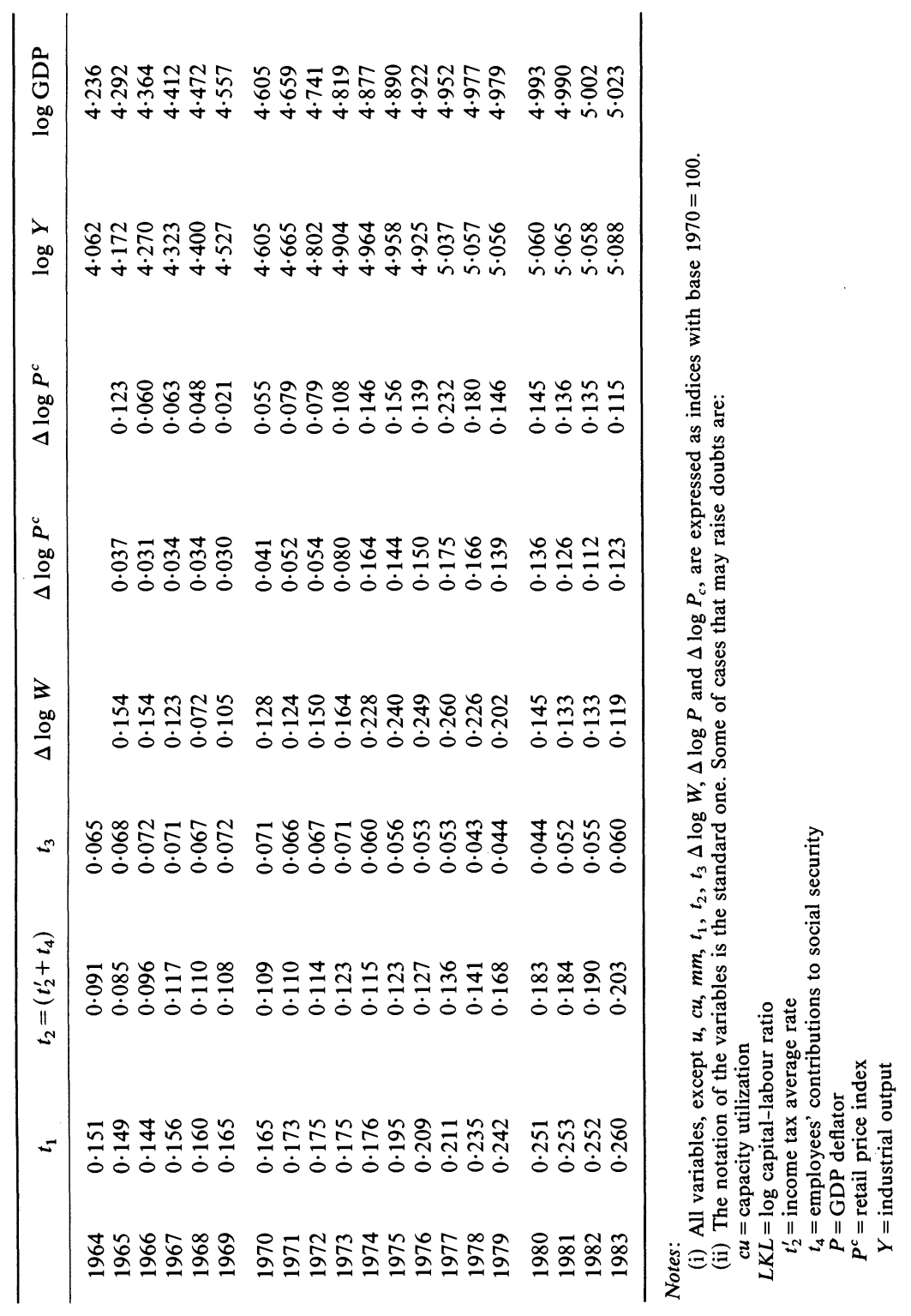




\section{Definitions}

$n \quad \log N ; N=$ total number of employees in industry (annual average) (BE) (elaborated from GTE and EPA). total unemployment rate in industry (annual average), excluding 'schoolleavers' $(B E)$ (elaborated from GTE and $E P A$ ).

$w \quad \log W ; W=$ average monthly earnings per employee $(B E)$ (elaborated from $E S)$.

$t_{1} \quad$ employer's mandatory contributions to social security; defined as the ratio of the average contribution per employee to the average wage in industry $(C N)$.

$p \quad \log P ; P=$ industrial output index; elaborated from the industrial component of the wholesale price index and the index of industrial prices $(B E)$.

$p^{c} \quad \log P^{c} ; P^{c}=$ index of consumer prices $(B E)$.

$p_{m} \quad \log P_{m} ; P_{m}=$ index of industrial import prices; elaborated as a weighted average of an index of domestic prices and the indices of unit value of imports of raw materials and semi-elaborated goods in industry $(B E)$.

$k \quad \log K ; K=$ capital stock; elaborated through the integration of flows of 'total gross domestic fixed capital formation' of the non-financial firms, as defined by the CN (see Dolado and Malo de Molina, 1984) (BE).

$Y \quad \log Y ; Y=$ index of value added in industry (CN).

a $\log A ; A=$ index of labour-augmenting technical progress. This is computed as follows. Starting from a value added production function.

$$
Y=F(N A, K) \text {, }
$$

by taking logs and differencing, we find that

$$
\Delta y=\left(1-v_{k}\right)(\Delta n+\Delta a)+v_{k} \Delta k
$$

where $v_{k}$ is the share of capital. Thus we have

$$
\Delta a=\left(1-v_{k}\right)^{-1}\left\{\Delta y-\left(1-v_{k}\right) \Delta n-v_{k} \Delta k\right\} .
$$

Then the variable is integrated taking an initial value. Since the production function refers to potential value added and we have used actual value added, the index might be underestimated. In order to somehow correct for this deficiency and to iron out cyclical components, the fitted values from a quadratic have been used. replacement ratio; defined as the ratio of unemployment subsidies per unemployed person to average earnings per employee $(B E L)$. Owing to its potential endogeneity, the following adjusted version was computed. An expected measure for an individual who has a probability of 0.5 of having a complete unemployment spell of 6 months or less, a probability of 0.3 of being unemployed between 6 and 12 months, a probability of 0.1 of unemployment between 12 and 18 months, and finally, a probability of 0.1 of being unemployed for longer than 18 months. The corresponding legal replacement ratios have been 0.8 for the first spell until 1965 , an additional 0.7 for the second spell between 1966 and 1975, an additional 0.6 for the third spell between 1976 and 1980, and an additional 0.5 for the fourth spell beyond 1980 . an index of firing costs; defined as the ratio of average redundancy payments as agreed by the Labour Court to average earnings per employee $(B E L)$. This variable was adjusted as follows. For a given individual with a duration of 5 years of employment in a firm, the redundancy payments, when fired, accounted for 100 per cent of his (her) annual earnings until 1979 and 90, 75, 75 and 70 per cent in 1980,1981, 1982 and 1983, respectively.

$\mathrm{mm}$ an index of mismatch; defined as the absolute change in the proportion of 'Total employees in industry (annual average)' relative to 'Total employees (annual average)' (GTE and EPA).

$t_{2} \quad$ labour income taxes; defined as the average rate of income tax that a single worker with the same real wage throughout the period would pay, plus the rate of employee's contributions to social security $(M E H)$. 
$t_{3} \quad$ indirect taxes; defined as the ratio of total indirect taxes net of subsidies to GDP at factor costs $(C N)$.

$e \quad \log E ; E=$ real exchange rate; defined as the ratio of an index of export prices of industrial countries in pesetas to an index of industrial prices $(B E)$.

$r \quad$ after-tax real interest rate; defined as $(1-\tau) R-\Delta p_{+1}$ where $\tau$ is the corporate tax rate, $R$ is the interest rate on bank credits between one and three years, and $p$ is as above $(B E)$. This variable was always instrumented to take account of the measurement error induced by using $\Delta p_{+1}$ as opposed to $\Delta p_{+1}^{e}$.

wt $\quad \log W T ; W T=$ index of world trade; defined as a quantum index of exports by industrial countries and LDC non-oil-exporting countries. The actual series used in the paper are the deviations of that index in logs from a third-degree polynomial in time (IFS).

$m \quad \log M ; M=\mathrm{M} 3$ nominal holdings (billions) $(B E)$.

$A D$ adjusted budget deficit as a proportion of GDP. The cyclically adjusted deficit has been taken from Viñals (1985).

Abbreviations for sources

BE Boletín Estadístico (Bank of Spain)

BEL Boletín de Estadísticas Laborales

CN Contabilidad Nacional

EPA Encuesta de Población Activa

ES Encuesta de Salarios

GTE Grupo de Trabajo del Ministerio de Economía

IFS International Financial Statistics

MEH Ministerio Economía y Hacienda 
UNITED KINGDOM

\begin{tabular}{|c|c|c|c|c|c|c|c|}
\hline & $\log N$ & $\log K$ & $\log (W / \bar{P})$ & $\nu$ & $A D$ & $\log \left(P^{*} / \bar{P}\right)$ & $W T$ \\
\hline \multicolumn{8}{|l|}{1950} \\
\hline \multicolumn{8}{|l|}{$\begin{array}{l}1951 \\
1952\end{array}$} \\
\hline 1953 & $9 \cdot 927$ & $5 \cdot 426$ & $4 \cdot 173$ & 0.236 & 0.097 & -0.556 & \\
\hline 1954 & $9 \cdot 944$ & $5 \cdot 452$ & $4 \cdot 220$ & 0.232 & 0.089 & -0.591 & -0.013 \\
\hline 1955 & $9 \cdot 958$ & $5 \cdot 477$ & $4 \cdot 254$ & $0 \cdot 243$ & 0.082 & -0.628 & -0.005 \\
\hline 1956 & $9 \cdot 970$ & $5 \cdot 502$ & $4 \cdot 292$ & 0.229 & 0.080 & -0.604 & 0.044 \\
\hline 1957 & $9 \cdot 974$ & $5 \cdot 528$ & $4 \cdot 292$ & 0.227 & 0.079 & -0.626 & 0.028 \\
\hline 1958 & $9 \cdot 966$ & $5 \cdot 553$ & $4 \cdot 326$ & 0.209 & 0.067 & -0.651 & -0.055 \\
\hline 1959 & 9.972 & $5 \cdot 580$ & $4 \cdot 350$ & $0 \cdot 211$ & 0.075 & -0.661 & -0.038 \\
\hline 1960 & $9 \cdot 994$ & $5 \cdot 618$ & $4 \cdot 408$ & $0 \cdot 226$ & 0.083 & -0.674 & 0.031 \\
\hline 1961 & 10.009 & $5 \cdot 651$ & $4 \cdot 443$ & $0 \cdot 211$ & 0.080 & $-0 \cdot 700$ & 0.001 \\
\hline 1962 & $10 \cdot 019$ & $5 \cdot 682$ & $4 \cdot 467$ & 0.205 & 0.074 & -0.728 & -0.010 \\
\hline 1963 & $10 \cdot 022$ & $5 \cdot 715$ & $4 \cdot 487$ & $0 \cdot 205$ & 0.079 & $-0 \cdot 728$ & 0.019 \\
\hline 1964 & $10 \cdot 035$ & $5 \cdot 749$ & $4 \cdot 518$ & $0 \cdot 213$ & $0 \cdot 088$ & -0.756 & 0.011 \\
\hline 1965 & $10 \cdot 047$ & $5 \cdot 790$ & $4 \cdot 569$ & $0 \cdot 203$ & 0.085 & -0.775 & 0.013 \\
\hline 1966 & $10 \cdot 054$ & $5 \cdot 825$ & 4.633 & $0 \cdot 197$ & 0.085 & -0.771 & 0.004 \\
\hline 1967 & $10 \cdot 035$ & $5 \cdot 867$ & $4 \cdot 643$ & $0 \cdot 203$ & 0.093 & -0.816 & -0.049 \\
\hline 1968 & $10 \cdot 028$ & $5 \cdot 908$ & $4 \cdot 672$ & $0 \cdot 224$ & 0.087 & -0.696 & -0.004 \\
\hline 1969 & $10 \cdot 027$ & $5 \cdot 951$ & $4 \cdot 706$ & $0 \cdot 220$ & 0.065 & -0.697 & 0.011 \\
\hline 1970 & $10 \cdot 020$ & $5 \cdot 989$ & $4 \cdot 801$ & $0 \cdot 225$ & 0.062 & -0.715 & 0.005 \\
\hline 1971 & $10 \cdot 004$ & $6 \cdot 026$ & $4 \cdot 842$ & $0 \cdot 220$ & 0.068 & -0.765 & -0.003 \\
\hline 1972 & $10 \cdot 004$ & $6 \cdot 061$ & 4.909 & $0 \cdot 223$ & 0.083 & -0.795 & 0.001 \\
\hline 1973 & $10 \cdot 028$ & 6.097 & 4.935 & $0 \cdot 267$ & 0.095 & $-0 \cdot 715$ & 0.046 \\
\hline 1974 & 10.034 & $6 \cdot 130$ & $4 \cdot 913$ & 0.336 & 0.097 & -0.674 & 0.031 \\
\hline 1975 & $10 \cdot 031$ & $6 \cdot 160$ & 4.973 & $0 \cdot 282$ & 0.092 & $-0 \cdot 717$ & -0.074 \\
\hline 1976 & $10 \cdot 023$ & $6 \cdot 190$ & $4 \cdot 944$ & $0 \cdot 300$ & 0.086 & -0.649 & -0.009 \\
\hline 1977 & $10 \cdot 026$ & $6 \cdot 217$ & $4 \cdot 910$ & $0 \cdot 299$ & 0.073 & -0.667 & -0.015 \\
\hline 1978 & $10 \cdot 033$ & $6 \cdot 244$ & $4 \cdot 966$ & $0 \cdot 278$ & 0.079 & $-0 \cdot 713$ & -0.002 \\
\hline 1979 & $10 \cdot 049$ & $6 \cdot 269$ & $5 \cdot 010$ & $0 \cdot 285$ & 0.077 & -0.796 & 0.036 \\
\hline 1980 & $10 \cdot 041$ & $6 \cdot 295$ & $5 \cdot 037$ & $0 \cdot 258$ & 0.069 & $-0 \cdot 941$ & 0.023 \\
\hline 1981 & $9 \cdot 992$ & $6 \cdot 312$ & $5 \cdot 052$ & $0 \cdot 247$ & 0.059 & -0.945 & -0.026 \\
\hline 1982 & $9 \cdot 971$ & $6 \cdot 330$ & $5 \cdot 072$ & $0 \cdot 270$ & 0.053 & $-0 \cdot 896$ & $-0 \cdot 101$ \\
\hline 1983 & $9 \cdot 955$ & $6 \cdot 346$ & $5 \cdot 075$ & $0 \cdot 247$ & 0.062 & $-0 \cdot 854$ & $-0 \cdot 165$ \\
\hline
\end{tabular}




\begin{tabular}{|c|c|c|c|c|c|c|c|}
\hline & $\log A$ & $U$ & $\log L$ & $M M$ & $\rho$ & $\begin{array}{c}\log Y^{P} \\
\text { (smoothed) }\end{array}$ & $\log \left(U_{p}\right)$ \\
\hline \multicolumn{8}{|l|}{1950} \\
\hline \multicolumn{8}{|l|}{$\begin{array}{l}1951 \\
1952\end{array}$} \\
\hline 1953 & & 0.017 & $9 \cdot 944$ & $0 \cdot 107$ & $40 \cdot 500$ & -0.030 & $-2 \cdot 408$ \\
\hline 1954 & 0.010 & 0.014 & $9 \cdot 958$ & $0 \cdot 160$ & $37 \cdot 800$ & 0.034 & $-2 \cdot 659$ \\
\hline 1955 & 0.021 & 0.011 & $9 \cdot 969$ & 0.487 & $37 \cdot 500$ & 0.067 & $-2 \cdot 408$ \\
\hline 1956 & 0.037 & 0.012 & 9.982 & $0 \cdot 161$ & $37 \cdot 700$ & 0.096 & -1.966 \\
\hline 1957 & 0.053 & $0 \cdot 016$ & $9 \cdot 990$ & 0.275 & $36 \cdot 200$ & $0 \cdot 127$ & $-1 \cdot 832$ \\
\hline 1958 & 0.067 & $0 \cdot 022$ & $9 \cdot 988$ & 0.244 & $40 \cdot 100$ & $0 \cdot 142$ & -1.897 \\
\hline 1959 & 0.084 & 0.024 & $9 \cdot 996$ & $0 \cdot 535$ & $40 \cdot 600$ & $0 \cdot 164$ & $-2 \cdot 040$ \\
\hline 1960 & $0 \cdot 107$ & $0 \cdot 018$ & $10 \cdot 012$ & $0 \cdot 359$ & $42 \cdot 000$ & $0 \cdot 196$ & $-1 \cdot 833$ \\
\hline 1961 & 0.132 & 0.017 & 10.026 & 0.065 & $42 \cdot 000$ & $0 \cdot 226$ & $-1 \cdot 772$ \\
\hline 1962 & $0 \cdot 157$ & 0.023 & $10 \cdot 042$ & 0.729 & $42 \cdot 400$ & $0 \cdot 254$ & $-1 \cdot 661$ \\
\hline 1963 & $0 \cdot 187$ & 0.028 & 10.050 & 0.668 & $43 \cdot 900$ & $0 \cdot 285$ & -1.897 \\
\hline 1964 & $0 \cdot 218$ & 0.020 & $10 \cdot 055$ & $0 \cdot 159$ & 43.000 & $0 \cdot 317$ & $-1 \cdot 832$ \\
\hline 1965 & 0.246 & $0 \cdot 017$ & $10 \cdot 064$ & $0 \cdot 061$ & $47 \cdot 500$ & $0 \cdot 351$ & $-1 \cdot 661$ \\
\hline 1966 & $0 \cdot 276$ & $0 \cdot 018$ & $10 \cdot 072$ & $0 \cdot 181$ & $48 \cdot 200$ & $0 \cdot 381$ & $-1 \cdot 772$ \\
\hline 1967 & $0 \cdot 309$ & $0 \cdot 030$ & $10 \cdot 065$ & $0 \cdot 586$ & $52 \cdot 600$ & 0.410 & $-1 \cdot 772$ \\
\hline 1968 & 0.344 & 0.033 & 10.061 & 0.534 & $51 \cdot 700$ & 0.442 & $-1 \cdot 619$ \\
\hline 1969 & 0.375 & 0.033 & $10 \cdot 060$ & $0 \cdot 031$ & $50 \cdot 800$ & 0.470 & $-1 \cdot 561$ \\
\hline 1970 & 0.407 & 0.036 & 10.056 & 0.487 & $51 \cdot 200$ & 0.496 & $-1 \cdot 347$ \\
\hline 1971 & 0.441 & 0.047 & 10.051 & 0.999 & $50 \cdot 600$ & 0.524 & $-1 \cdot 347$ \\
\hline 1972 & 0.471 & 0.051 & 10.055 & $1 \cdot 270$ & $47 \cdot 000$ & 0.552 & $-1 \cdot 171$ \\
\hline 1973 & 0.501 & 0.036 & $10 \cdot 064$ & 0.603 & $46 \cdot 600$ & 0.587 & $-1 \cdot 171$ \\
\hline 1974 & 0.524 & 0.036 & $10 \cdot 070$ & $0 \cdot 311$ & $47 \cdot 200$ & $0 \cdot 613$ & $-1 \cdot 386$ \\
\hline 1975 & 0.545 & 0.055 & $10 \cdot 086$ & $1 \cdot 542$ & $49 \cdot 200$ & 0.640 & $-1 \cdot 171$ \\
\hline 1976 & 0.560 & $0 \cdot 071$ & 10.094 & 0.793 & $50 \cdot 000$ & 0.664 & $-1 \cdot 204$ \\
\hline 1977 & 0.577 & 0.074 & $10 \cdot 100$ & 0.095 & $51 \cdot 300$ & 0.687 & $-1 \cdot 139$ \\
\hline 1978 & $0 \cdot 591$ & 0.072 & $10 \cdot 105$ & $0 \cdot 432$ & $49 \cdot 800$ & $0 \cdot 701$ & $-1 \cdot 273$ \\
\hline 1979 & $0 \cdot 612$ & 0.067 & $10 \cdot 116$ & $0 \cdot 518$ & $46 \cdot 000$ & $0 \cdot 722$ & $-1 \cdot 238$ \\
\hline 1980 & 0.627 & 0.087 & $10 \cdot 128$ & $1 \cdot 012$ & $45 \cdot 800$ & $0 \cdot 740$ & -0.892 \\
\hline 1981 & 0.641 & $0 \cdot 137$ & $10 \cdot 129$ & $1 \cdot 807$ & $50 \cdot 300$ & 0.745 & -0.832 \\
\hline 1982 & 0.659 & $0 \cdot 160$ & $10 \cdot 131$ & 1.076 & $53 \cdot 500$ & 0.756 & $-0 \cdot 842$ \\
\hline 1983 & 0.681 & $0 \cdot 167$ & $10 \cdot 122$ & 0.986 & $54 \cdot 400$ & 0.766 & -0.846 \\
\hline
\end{tabular}




\begin{tabular}{|c|c|c|c|c|c|c|}
\hline & $t_{1}$ & $t_{2}$ & $t_{3}$ & $V$ & $\log P O P$ & $\log G$ \\
\hline 1950 & $4 \cdot 503$ & & & & & \\
\hline 1951 & $4 \cdot 498$ & & & & & \\
\hline 1952 & $4 \cdot 505$ & & & & & \\
\hline 1953 & $4 \cdot 503$ & 0.086 & 0.029 & 0.044 & $10 \cdot 426$ & $9 \cdot 561$ \\
\hline 1954 & $4 \cdot 506$ & 0.086 & 0.025 & 0.051 & $10 \cdot 426$ & $9 \cdot 507$ \\
\hline 1955 & $4 \cdot 507$ & 0.090 & 0.027 & 0.062 & $10 \cdot 427$ & $9 \cdot 494$ \\
\hline 1956 & $4 \cdot 507$ & 0.093 & 0.029 & 0.053 & $10 \cdot 426$ & $9 \cdot 523$ \\
\hline 1957 & $4 \cdot 505$ & 0.098 & 0.026 & $0 \cdot 041$ & $10 \cdot 427$ & $9 \cdot 521$ \\
\hline 1958 & $4 \cdot 512$ & $0 \cdot 110$ & 0.019 & 0.030 & $10 \cdot 429$ & $9 \cdot 491$ \\
\hline 1959 & $4 \cdot 512$ & $0 \cdot 108$ & 0.015 & 0.035 & $10 \cdot 434$ & $9 \cdot 534$ \\
\hline 1960 & $4 \cdot 510$ & $0 \cdot 110$ & 0.010 & 0.046 & $10 \cdot 440$ & $9 \cdot 568$ \\
\hline 1961 & $4 \cdot 509$ & 0.116 & 0.010 & 0.045 & $10 \cdot 446$ & $9 \cdot 618$ \\
\hline 1962 & $4 \cdot 513$ & $0 \cdot 123$ & 0.015 & 0.031 & $10 \cdot 459$ & $9 \cdot 658$ \\
\hline 1963 & $4 \cdot 516$ & $0 \cdot 122$ & 0.014 & 0.030 & $10 \cdot 461$ & $9 \cdot 691$ \\
\hline 1964 & $4 \cdot 511$ & $0 \cdot 127$ & 0.020 & 0.046 & $10 \cdot 465$ & 9.756 \\
\hline 1965 & $4 \cdot 517$ & $0 \cdot 141$ & 0.030 & 0.054 & $10 \cdot 462$ & $9 \cdot 803$ \\
\hline 1966 & $4 \cdot 545$ & $0 \cdot 152$ & 0.036 & 0.052 & $10 \cdot 463$ & $9 \cdot 856$ \\
\hline 1967 & $4 \cdot 551$ & 0.153 & 0.037 & 0.036 & $10 \cdot 462$ & $9 \cdot 941$ \\
\hline 1968 & $4 \cdot 556$ & $0 \cdot 167$ & 0.048 & $0 \cdot 040$ & $10 \cdot 464$ & $9 \cdot 981$ \\
\hline 1969 & $4 \cdot 563$ & 0.175 & 0.067 & 0.042 & $10 \cdot 463$ & $9 \cdot 986$ \\
\hline 1970 & $4 \cdot 568$ & $0 \cdot 186$ & 0.063 & $0 \cdot 040$ & $10 \cdot 462$ & $10 \cdot 021$ \\
\hline 1971 & $4 \cdot 568$ & $0 \cdot 188$ & 0.048 & 0.026 & $10 \cdot 462$ & 10.034 \\
\hline 1972 & $4 \cdot 571$ & $0 \cdot 178$ & 0.027 & 0.029 & $10 \cdot 462$ & $10 \cdot 051$ \\
\hline 1973 & $4 \cdot 583$ & $0 \cdot 186$ & 0.019 & 0.056 & $10 \cdot 464$ & $10 \cdot 142$ \\
\hline 1974 & $4 \cdot 579$ & $0 \cdot 209$ & 0.002 & 0.051 & $10 \cdot 465$ & $10 \cdot 195$ \\
\hline 1975 & $4 \cdot 605$ & 0.237 & 0.000 & 0.026 & $10 \cdot 466$ & $10 \cdot 245$ \\
\hline 1976 & $4 \cdot 619$ & $0 \cdot 245$ & 0.006 & 0.021 & $10 \cdot 469$ & $10 \cdot 251$ \\
\hline 1977 & $4 \cdot 634$ & 0.233 & 0.022 & 0.025 & $10 \cdot 473$ & $10 \cdot 192$ \\
\hline 1978 & $4 \cdot 641$ & 0.223 & 0.016 & 0.031 & $10 \cdot 477$ & $10 \cdot 181$ \\
\hline 1979 & $4 \cdot 648$ & $0 \cdot 213$ & 0.032 & 0.032 & $10 \cdot 482$ & $10 \cdot 202$ \\
\hline 1980 & $4 \cdot 646$ & $0 \cdot 220$ & 0.040 & 0.019 & $10 \cdot 485$ & $10 \cdot 252$ \\
\hline 1981 & $4 \cdot 648$ & $0 \cdot 238$ & 0.046 & 0.013 & $10 \cdot 493$ & $10 \cdot 236$ \\
\hline 1982 & $4 \cdot 642$ & $0 \cdot 243$ & 0.057 & 0.015 & $10 \cdot 161$ & $10 \cdot 248$ \\
\hline 1983 & $4 \cdot 633$ & $0 \cdot 244$ & 0.047 & 0.020 & $10 \cdot 160$ & $10 \cdot 294$ \\
\hline
\end{tabular}




\begin{tabular}{|c|c|c|c|c|c|c|}
\hline & $\log \left(P_{m} / \bar{P}\right)$ & $\sigma($ Model 1) & $\log (K / L)$ & $B / Y^{P}$ & OIL & $\tau$ \\
\hline 1950 & & & $-4 \cdot 573$ & & & $0 \cdot 285$ \\
\hline 1951 & & & $-4 \cdot 556$ & & & $0 \cdot 321$ \\
\hline 1952 & & & $-4 \cdot 536$ & & & $0 \cdot 295$ \\
\hline 1953 & & & $-4 \cdot 518$ & & & $0 \cdot 301$ \\
\hline 1954 & 0.028 & $0 \cdot 355$ & $-4 \cdot 506$ & $6 \cdot 500$ & & $0 \cdot 252$ \\
\hline 1955 & $0 \cdot 230$ & $0 \cdot 245$ & $-4 \cdot 492$ & $-7 \cdot 990$ & & $0 \cdot 256$ \\
\hline 1956 & $0 \cdot 206$ & $0 \cdot 304$ & $-4 \cdot 480$ & $9 \cdot 952$ & & $0 \cdot 245$ \\
\hline 1957 & $0 \cdot 170$ & $0 \cdot 256$ & $-4 \cdot 463$ & $10 \cdot 543$ & & $0 \cdot 232$ \\
\hline 1958 & 0.077 & 0.019 & $-4 \cdot 435$ & $15 \cdot 584$ & & $0 \cdot 175$ \\
\hline 1959 & 0.058 & $0 \cdot 111$ & $-4 \cdot 416$ & $7 \cdot 078$ & & $0 \cdot 171$ \\
\hline 1960 & 0.044 & $0 \cdot 249$ & $-4 \cdot 394$ & $-8 \cdot 871$ & & $0 \cdot 162$ \\
\hline 1961 & -0.005 & $0 \cdot 159$ & $-4 \cdot 374$ & $1 \cdot 710$ & & $0 \cdot 123$ \\
\hline 1962 & -0.040 & 0.059 & $-4 \cdot 360$ & $5 \cdot 382$ & & 0.097 \\
\hline 1963 & -0.026 & $0 \cdot 137$ & $-4 \cdot 334$ & $4 \cdot 085$ & & $0 \cdot 105$ \\
\hline 1964 & -0.029 & $0 \cdot 203$ & $-4 \cdot 306$ & $-10 \cdot 719$ & & 0.098 \\
\hline 1965 & -0.065 & $0 \cdot 149$ & $-4 \cdot 274$ & -0.836 & & 0.048 \\
\hline 1966 & -0.087 & $0 \cdot 144$ & $-4 \cdot 247$ & $3 \cdot 403$ & & $0 \cdot 136$ \\
\hline 1967 & $-0 \cdot 118$ & $0 \cdot 133$ & $-4 \cdot 198$ & $-6 \cdot 642$ & & $0 \cdot 104$ \\
\hline 1968 & -0.051 & $0 \cdot 241$ & $-4 \cdot 153$ & $-5 \cdot 545$ & & 0.083 \\
\hline 1969 & -0.061 & $0 \cdot 011$ & $-4 \cdot 109$ & $10 \cdot 745$ & & 0.046 \\
\hline 1970 & -0.092 & -0.040 & $-4 \cdot 067$ & $15 \cdot 981$ & & $0 \cdot 044$ \\
\hline 1971 & $-0 \cdot 130$ & -0.035 & $-4 \cdot 025$ & $19 \cdot 446$ & & 0.022 \\
\hline 1972 & $-0 \cdot 158$ & 0.098 & $-3 \cdot 994$ & $3 \cdot 484$ & & 0.002 \\
\hline 1973 & -0.014 & $0 \cdot 356$ & -3.968 & $-13 \cdot 230$ & & 0.021 \\
\hline 1974 & $0 \cdot 161$ & 0.405 & $-3 \cdot 940$ & -38.977 & & 0.092 \\
\hline 1975 & $0 \cdot 080$ & $0 \cdot 198$ & $-3 \cdot 925$ & $-14 \cdot 327$ & 0.017 & $-0 \cdot 191$ \\
\hline 1976 & $0 \cdot 132$ & $0 \cdot 270$ & $-3 \cdot 904$ & $-6 \cdot 672$ & $0 \cdot 120$ & $-0 \cdot 133$ \\
\hline 1977 & $0 \cdot 150$ & 0.099 & $-3 \cdot 883$ & 0.363 & $0 \cdot 372$ & $0 \cdot 010$ \\
\hline 1978 & $0 \cdot 100$ & $0 \cdot 137$ & $-3 \cdot 861$ & $6 \cdot 917$ & 0.492 & 0.038 \\
\hline 1979 & 0.079 & 0.074 & $-3 \cdot 847$ & $-2 \cdot 673$ & 0.720 & -0.025 \\
\hline 1980 & 0.067 & $-0 \cdot 169$ & $-3 \cdot 833$ & $15 \cdot 765$ & $0 \cdot 727$ & $0 \cdot 128$ \\
\hline 1981 & 0.050 & -0.336 & $-3 \cdot 817$ & $28 \cdot 407$ & 0.685 & 0.042 \\
\hline 1982 & 0.077 & -0.424 & $-3 \cdot 801$ & $18 \cdot 774$ & 0.671 & 0.091 \\
\hline 1983 & $0 \cdot 105$ & -0.357 & $-3 \cdot 776$ & $9 \cdot 678$ & $0 \cdot 704$ & $0 \cdot 156$ \\
\hline
\end{tabular}

Data sources and definitions

Abbreviations

AAS
$B B$
$B E Q B$
$B E S A 70$
$B E S A 75$
$B L S H A$
$D E G$
ETAS
ET
FS
MDS
NIER
YB

Annual Abstract of Statistics

'Blue Book', National Income and Expenditure (yearly).

Bank of England Quarterly Bulletin

Bank of England Statistical Abstract, 1970

Bank of England Statistical Abstract, 1975 (BESA only published twice)

British Labour Statistics, Historical Abstract, 1886-1968

Department of Employment Gazette (monthly)

Economic Trends Annual Supplement

Economic Trends (monthly)

Financial Statistics (monthly)

Monthly Digest of Statistics

National Institute Economic Review

British Labour Statistics Year Book, 1969-1976 (published eight times, between 1969 and 1976)

(Data relate to UK unless otherwise stated.) 
$N$ Employees in employment, males and females, mid-year, Great Britain (ETAS).

K Capital stock. The series used is 'gross capital stock at 1975 replacement cost', in $£$ billion. Data are available yearly from 1958 onward in successive issues of the $B B$, at various base years (which were easily 'spliced' together). Before 1958 only the 1954,1951 and 1948 observations were published. Data were interpolated using real investment data, namely 'total gross domestic fixed capital formation', $£$ million at 1975 prices, using the usual technique involving the estimation of a decay parameter $\hat{\delta}$ from the postulated relationship,

$$
K_{n}=\sum_{i=1}^{n}(1-\delta)^{n-i} I_{i}+(1-\delta)^{n} K_{0}
$$

where $K_{n}, K_{0}$ are end of period and beginning of period capital stocks, and $I_{i}$ is investment. The missing $K$ 's are calculated recursively by setting $n=1$ each time, and using $\hat{\delta}$. The investment series is published in ETAS.

$(W / P)$ The real product wage. $W$ is a labour cost variable equal to $\bar{W}\left(1+t_{1}\right) \cdot \bar{W}$ is the pre-tax wage calculated as follows. We first take $E$ and $H$, the average weekly earnings and average weekly hours of full-time male manual workers ( 21 years and over), at October in each year, for all industries covered; and $N^{h}$, the average normal weekly hours of male manual workers, for all industries and services. Given an overtime premium of $0 \cdot 3$, we now compute $\bar{W}$ as the hourly earnings if the individual works 45 hours per week. Thus

$$
\bar{W}=\frac{E\left\{N^{h}+1 \cdot 3\left(45-N^{h}\right)\right\}}{45\left\{N^{h}+1 \cdot 3\left(H-N^{h}\right)\right\}}
$$

All data for $E, H$ and $N^{h}$ are published in $B L S H A, Y B$ and the latest issue of $D E G$.

$\nu \quad$ Ratio of imports to GDP.

$A D \quad$ Adjusted public sector deficit as a percentage of potential GDP. We calculate the weighted, cyclically adjusted deficit by the method described in NIER $3 / 85$, but with the following alterations: (1) the weights used on current expenditures and capital expenditures are reduced to 0.82 and 0.77 to capture the impact effects of these items on home demand; (2) instead of debt interest, we use $0.02 \times$ volume of public sector debt outstanding (AAS) as an adjustment for the inflation tax.

$P^{*} / \bar{P} \quad$ This is a measure of competitiveness. $P^{*}$ is the unit value index of world manufacturing exports from the UN Monthly Digest of Statistics. This is converted from dollars to pounds using the $\$ / £$ exchange range (ETAS).

WT This measures the deviation of world trade from trend. The world trade measure is the log of the quantum index of world exports (WE) from the UN Monthly Digest of Statistics. The actual variable consists of the residuals from the regression

$$
\begin{aligned}
\log (W E)= & 1.53+0.50 t-0.057 t^{2}+0.0033 t^{3}-0.000086 t^{4} \\
& (2 \cdot 5) \quad(2 \cdot 5) \quad(2 \cdot 7) \quad(2 \cdot 7) \\
& +0 \cdot 00000081 t^{5} \\
& (2 \cdot 7)
\end{aligned}
$$

A Index of labour-augmenting technical progress. This is computed via the formula

$$
\Delta \log A_{t}=\frac{1}{\left(1-\nu_{K t}\right)}\left\{\Delta \log Y_{t}-\left(1-\nu_{K t}\right) \Delta \log N_{t}-\nu_{K t} \Delta \log K_{t}\right\}
$$

$Y_{t}$ is GDP at factor cost $(E T A S)$ and the weights are defined using the variables 'compensation of employees' and 'operating surplus' which are rows 17 and 18 in the UK table of National Accounts of OECD Countries (Paris, 1981). The series used in the annual estimation procedure corresponds to a five-year moving average of the ' $A$ ' index. 
$U \quad$ Male unemployment rate. The series used is 'males wholly unemployed as a percentage of the number of employees (employed and unemployed) at the appropriate mid-year, for the UK'. The numbers unemployed exclude 'temporarily stopped' but include school-leavers. The data are published in $B L S H A$, the $Y B$, and finally $D E G$. We consider the male rate to be the most accurate available measure of the aggregate unemployment rate (including unregistered women). The data refer to the pre-1982 definition of the male unemployment rate; more recent data have been appropriately adjusted.

$L \quad$ Labour force, defined by $\log L=U+\log N$. (Note that $\log L-\log N=$ $-\log N / L=-\log \{1-(L-N) / L\}=L-N / L=U$. $)$ This definition of the labour force is consistent with the view expressed under $U$ above.

MM An index of mismatch. This is the absolute change in the proportion of 'employees in employment, males and females, in index of production industries at each mid-year, Great Britain', to 'total employees in employment, males and females at each mid-year, Great Britain' (BLSHA, YB, DEG).

$\rho \quad$ The replacement ratio. This variable is measured as a weighted average of different family types using the following proportions: single householder $0 \cdot 35$, married couple with no children $0 \cdot 12$, with one child $0 \cdot 11$, with two children $0 \cdot 16$ and with three children $0 \cdot 12$. The components of this weighted average are calculated from Table 6.4a of the DHSS Abstract of Statistics for Index of Retail Prices, Average Earnings, Social Security Benefits and Contributions (1983). This gives for each family type, data on supplementary benefits, plus rent addition and on net income for a one-earner family on average earnings. We compute annual income on benefit and relate it to mid-year earnings.

$Y^{P} \quad$ Potential GDP, constructed from the equation

$$
\Delta \log Y_{t}^{P}=\left(1-\nu_{K t}\right) \Delta \log L_{t}+\nu_{K t} \Delta \log K_{t}+\left(1-\nu_{K t}\right) \Delta \log A_{t}
$$

where $L$ refers to the labour force.

$U_{p} \quad$ Our measure of union power is the log of the union/non-union mark-up $(U M)$. The procedure by which this variable was estimated is described in Layard, Metcalf and Nickell (1978, Table 5).* Cross-section regressions have been estimated for each year, 1953-83. The modified series is plotted in Figure 3 of the text alongside series derived from $D E G$ on strike activity and union membership.

$t_{1} \quad$ The 'employment tax' borne by the firm. This series is calculated by taking the ratio of two indices, the 'total labour costs per unit of output for the whole economy', $1975=100$, and 'wages and salaries per unit of output for the whole economy', $1975=100$. However, it is an index based at $1975=100$. Thus the only way to obtain an approximation to $t_{1 t}$ is to take $\operatorname{logs}\left(\log k\left(1+t_{1 t}\right)=\right.$ $\left.\log k+t_{1 t}\right)$ and let $\log k$ be absorbed by the regression constant. The former series is published in BLSHA (Table 203), YB 1976 (Table 55) and the latest issue of $D E G$; the latter series is in ETAS.

$t_{2}$ Income tax rate, computed as follows:

$$
t_{2}=(D T+S S) / H C R \text {. }
$$

where $D T$ is direct taxes on household income, $S S$ is households' contributions to social security schemes, and HCR is households' current receipts minus employer contributions to social security schemes. All three series are from OECD National Accounts.

$t_{3}$ The indirect tax rate. The log of the ratio of the GDP deflator at market prices $(1975=100)$ to the GDP deflator at factor cost $(1975=100)$ yields $t_{3}+$ constant (ETAS).

$V \quad$ Vacancy rate. This is defined by $V=\left(V^{\prime} \times 10^{3}\right) / \lambda N$, where $V^{\prime}=$ registered vacancies $(D E G)$,

$$
\lambda=\mathbf{a} \text { correction factor }
$$

\footnotetext{
* See Reference list at end of paper.
} 


$$
\begin{aligned}
= & \frac{1}{2}\left\{\left(\frac{\text { outflow of registered vacancies }}{\text { engagements }}\right)\right. \\
& \left.+\left(\frac{\text { inflow of registered vacancies }}{\text { separations }}\right)\right\} .
\end{aligned}
$$

$\lambda$ is discussed in Jackman et al. (1984).

$P O P \quad$ Working population $(D E G)$.

$G \quad$ Real government expenditure. $G$ is calculated from 'general government expenditure on goods and services', in $£$ million, which is divided by the GDP at factor cost deflator. The GDP iactor cost deflator was used because the equivalent series at constant prices do not exist (ETAS).

$P_{m} \quad$ Import price index for the UK (ETAS).

$P \quad$ A value-added price index. We define it by

$$
(1+\nu) \log \bar{P}=\log P+\nu \log P_{m}
$$

where $\bar{P}$ is a gross output price index, $P_{m}$ is an import price index and $\nu$ is the share of imports in value added.

$\bar{P} \quad$ The output price index. $\bar{P}$ is defined as the TFE deflator at market prices $(B B)$ divided by $(1+N T 3)$ where $N T 3$ is the indirect tax rate relevant to the $T F E$ deflator. This is defined as $N T 3=F C A /(T F E-F C A)$ where $T F E=$ total final expenditure at market prices $(E T A S) ; F C A=$ factor cost adjustment which is expenditure taxes $(E T A S)$ - selective employment tax $(B B)$ - national insurance surcharge $(B B)$-subsidies (ETAS).

IPD Incomes policy dummy. The variable is unity in 1976 and 1977 , zero otherwise.

RI Post-tax real interest rate. This is defined as $\left(1-\tau_{c t}\right) R_{t}-\Delta \log P_{t+1}$ where $\tau_{c}$ is the corporate tax rate, $R_{t}$ is the Treasury bill rate and $P_{t}$ is as above (FS). This variable is always instrumented to take account of the measurement error induced by using $\Delta \log P_{t+1}$ as opposed to $\Delta \log P_{t+1}^{e}$.

$B / Y^{p}$ Total current balance of trade (exports-imports) (ETAS) divided by $Y^{p}$ (potential GDP).

OIL Real output of oil:

$O I L=\frac{\text { crude oil output (barrels) } \times \text { price of crude oil (per barrel) }}{\bar{P}}$.

The data on crude oil output and the relevant price per barrel are found in the Annual Report of the British National Oil Corporation.

$\tau \quad$ The effective average corporate tax rate defined for the whole economy, following the procedure proposed by King (1975) and Beath (1979). The effective tax liability is described by

$$
T=t(\Pi-D)+t_{d} \phi-\Sigma
$$

where $\Pi$ is gross trading profits, $\Delta$ is tax deductions, $\phi$ is gross dividends, $\Sigma$ is investment grants, $t$ is the corporate tax rate and $t_{d}$ is personal tax rate on dividend income. The component series were obtained on an annual basis from the following sources:

$\Pi \quad$ Gross trading profits after deduction of stock appreciation allowable for tax purposes, per companies and financial institutions (ETAS). (Stock appreciation was allowable against tax liability for 1975-83.)

$\phi \quad$ Dividends paid on ordinary shares by companies and financial institutions $(E T A S)$. This series was adjusted for personal income tax post-1973, as prior to that data it was reported gross of tax payments.

$\Sigma \quad$ Investment grants received by industrial and commercial companies $(B B)$.

$D \quad$ Interest payments by companies and financial institutions ('other' payments) $(E T A S)$; capital consumption allowances are given by gross profits less net profits $(B B)$.

The effective tax rate is given as the ratio of the annual tax liability series to gross trading profits. Following Beath (1979), the variable appears in the regressions as $(1-\tau)^{-1}$. Negative liabilities were set equal to zero. 